University of Rhode Island

DigitalCommons@URI

Open Access Master's Theses

2013

\title{
Analysis of Tunnel Production Systems and Consumer Preference for Muskmelon in Southern New England
}

Mina Vescera

University of Rhode Island, mina.vescera@gmail.com

Follow this and additional works at: https://digitalcommons.uri.edu/theses

\section{Recommended Citation}

Vescera, Mina, "Analysis of Tunnel Production Systems and Consumer Preference for Muskmelon in Southern New England" (2013). Open Access Master's Theses. Paper 70.

https://digitalcommons.uri.edu/theses/70

This Thesis is brought to you for free and open access by DigitalCommons@URI. It has been accepted for inclusion in Open Access Master's Theses by an authorized administrator of DigitalCommons@URI. For more information, please contact digitalcommons-group@uri.edu. 


\author{
ANALYSIS OF TUNNEL PRODUCTION SYSTEMS \\ AND CONSUMER PREFERENCE FOR MUSKMELON \\ IN SOUTHERN NEW ENGLAND \\ BY \\ MINA VESCERA
}

\begin{abstract}
A THESIS SUBMITTED IN PARTIAL FULFILLMENT OF THE
REQUIREMENTS FOR THE DEGREE OF

MASTER OF SCIENCE

IN

BIOLOGY AND ENVIRONMENTAL SCIENCE
\end{abstract}

UNIVERSITY OF RHODE ISLAND

2013 


\title{
MASTER OF SCIENCE \\ $\mathrm{OF}$ \\ MINA VESCERA
}

\section{APPROVED:}

Thesis Committee:

\author{
Major Professor Rebeca N. Brown \\ Howard S. Ginsberg \\ Thomas Sproul
}

Nasser H. Zawia

DEAN OF THE GRADUATE SCHOOL

\section{UNIVERSITY OF RHODE ISLAND \\ 2013}




\begin{abstract}
This study investigated whether muskmelon (Cucumis melo L. var. reticulates), a high-value, warm-season vegetable, would be a suitable crop for tunnel production in southern New England, and if consumers would value local production of muskmelon. In New England, muskmelon (marketed as cantaloupe) is more commonly available to consumers at the supermarket than at farmers' markets. Direct-to-consumer sales are a common and important marketing tool used by growers in this region. The New England climate does not always provide the optimal growing conditions for muskmelon production. Tunnel production is becoming increasingly popular in New England because tunnels allow growers to extend and diversify crop production, and respond to consumer demand for increased production of local produce. The objectives of this study were to evaluate muskmelon tunnel production systems, test pollinator effectiveness within the high tunnels, and explore consumer preference for local muskmelon.
\end{abstract}

Three tunnel production systems were tested using a randomized complete block design: (1) three Gothic-styled high tunnels $(22 \times 6 \mathrm{~m})$ equipped with a ridge vent covered with a single layer of 6-mil (0.153-mm), 4-year Tufflite IV greenhouse polyethylene, (2) six low tunnels constructed with galvanized wire hoops (0.6 meter height) and covered with perforated (2011) or slitted (2012) clear 1-mil, and 0.8-mil plastic, respectively, and (3) six control tunnels similar in construction to the low tunnels, but covered with Agribon-15 in 2011 and ProtekNet in 2012. During the 2011 and 2012 growing seasons, seven cultivars ('Athena', 'Earlichamp', 'Lil Loupe', 'Sivan', 'Sarah's Choice', 'Sweet Granite', and 'Tasty Bites') suitable for the region 
were examined for earliness, yield and quality response to each tunnel system. Quality was measured by percent soluble solids. In both years, the low tunnel produced the greatest yields and sweetest fruit, with significantly greater and sweeter production in 2012 when compared to the high or control tunnels. The high tunnel produced the earliest yields in both years. Not all cultivars tested were suitable for high tunnel production.

Pollination was tested by comparing yields from three pollination systems. Pollination systems were not replicated because only three high tunnels were available for use. Cultivar test plots provided replication (ten per tunnel) for the response variables (total yield and percent soluble solids). The three pollination systems were: European honey bee (Apis mellifera) hive within an open tunnel; eastern bumble bee (Bombus impatiens) hive (adequate for up to 454 square meters) within a screened tunnel; and an open tunnel without a hive but accessible by wild bees and honey bees from nearby hives. All three systems produced quality fruit. Use of managed hives inside the tunnel is not necessary if wild populations or field hives are present.

In 2012, a survey and blind taste test at three Rhode Island farmers' markets was conducted to test for consumers' willingness to pay for local muskmelons, and their quality preferences for melons. Supermarket melons and melons grown for the production test were used for the taste test. A total of 102 respondents participated in the survey and blind taste test. More participants purchased melons only during the summer (46 percent) than throughout the year (43 percent), and only 13 percent rarely or never purchased melons. The majority of participants purchased cantaloupe at the supermarket, but more than 75 percent would purchase locally-grown melons if 
available at their farmers' markets. Most participants (58 percent) stated they would be willing to pay a premium price for locally-grown melons. When participants were asked to state how much more they would be willing to pay for their chosen melon from the taste test, values were not consistent. Sweetness was the most important attribute chosen by participants in deciding which melon sample they preferred. Analysis revealed that participants correctly chose the sweetest melon, but they were inclined to fail control trials (same-melon pairings).

The results of this study show that growers can successfully produce muskmelon in southern New England, with greatest success achieved using low tunnels, and that consumers would purchase locally-grown muskmelons priced at a premium over outof-region melons. Choosing suitable cultivars for the region and production systems is important. 


\section{ACKNOWLEDGEMENTS}

Thank you to the members of my thesis committee, your generosity of time and patience was very much appreciated. Many thanks to Dr. Rebecca Brown for her wise guidance, patience, and extraordinary editing skills. Thank you to Dr. Howard Ginsberg for his valuable assistance in my statistical analyses and for tutoring me in pollination ecology. Thank you to Dr. Thomas Sproul for helping me understand difficult concepts in my consumer preference research.

To the incredible summer research farm crews, thank you for making the summers more than just work and research! Thank you to research assistant Tim Sherman for his tireless support throughout this entire process; your patience amazed me! I am grateful for farm manager Carl Sawyer's willingness to share his expertise and knowledge whenever I needed his help. To Jeff Pieper and Noah LeClaireConway, thanks for being so supportive and helpful, and for making our corner of Woodward Hall more than just the copy and mail room. And thank you, Jeff, for being the best officemate ever! I am so grateful to the tireless undergraduates that aided me in heat of the summer--Jackie Iacobbo, Katie Schortman, and Justin Oulette--it was so much better with you there!

Thank you to my parents for being so incredibly supportive. I am entirely appreciative of your thoughtful assistance! And to Winter and Aegis, thank you for being the sweetest pups ever and for always wagging your tails when I came home. 


\section{PREFACE}

This thesis is written in manuscript format. A total of three chapters are written for publication in the journal HortScience. 


\section{TABLE OF CONTENTS}

ABSTRACT ii

ACKNOWLEDGEMENTS V v

PREFACE vi

TABLE OF CONTENTS vii

LIST OF TABLES ix

LIST OF FIGURES $\quad$ x

CHAPTER 1: INTRODUCTION

LITERATURE REVIEW 4

CHAPTER 2: A COMPARATIVE ANALYSIS OF TUNNEL PRODUCTION SYSTEMS FOR MUSKMELON IN RHODE ISLAND 29

$\begin{array}{ll}\text { Introduction } & \mathbf{3 0}\end{array}$

$\begin{array}{ll}\text { Methods } & 32\end{array}$

$\begin{array}{ll}\text { Results } & 38\end{array}$

Discussion 49

$\begin{array}{ll}\text { Conclusion } & 61\end{array}$

$\begin{array}{lr}\text { References } & 63\end{array}$

CHAPTER 3: AN INVESTIGATION OF POLLINATION SYSTEMS IN

GOTHIC-STYLED HIGH TUNNELS IN SOUTHERN NEW ENGLAND 84

$\begin{array}{ll}\text { Introduction } & \mathbf{8 5}\end{array}$

$\begin{array}{ll}\text { Methods } & 86\end{array}$

$\begin{array}{lr}\text { Results } & 90\end{array}$

$\begin{array}{ll}\text { Discussion } & 91\end{array}$

$\begin{array}{lr}\text { Conclusion } & 96\end{array}$ 
CHAPTER 4: CONSUMER PREFERENCE FOR LOCALLY-GROWN MUSKMELON: A CONJOINT ANALYSIS OF WILLINGNESS-TO-PAY AND

Introduction

Methods

105

Results and Discussion

Conclusion

113

References

CONCLUSION

123

APPENDIX

125

BIBLIOGRAPHY

134 


\section{LIST OF TABLES}

1. Seeding and planting dates by treatment and year. 68

2. First harvest dates are listed by cultivar and treatment. 69

3. Peak harvest represents the days during which the majority of fruit was harvested.70

4. Rowcover microclimate effects on mean air and soil temperatures. Minimum and maximum temperatures listed represent the absolute lowest and highest temperatures for the climate data collection period. Data are missing for open field 2011 soil temperatures and 2012 control air temperatures due to data logger malfunction. $\quad 71$ 5. Average fruit size per cultivar by treatment. Weights per cultivar represent average fruit weights from six plots containing five plants each. Commercial average was obtained from seed source.

6. Average percent soluble solids across cultivars and treatments per growing season.

'Sweet Granite' and 'Earlichamp' were grown in one growing season only.

7. Total weight per cultivar in center and edge plots in the high tunnel treatment. 74

8. Percent soluble solids associated with cantaloupe type and farmer's market.

Markets are organized by order of occurrence. Two cultivars were used for "cultivar 2" because marketable "Sarah's Choice" cantaloupes were no longer available for the Armory Market.

9. Willingness-to-pay fixed effects regression model.

10. Logistic regression model for quality. 


\section{LIST OF FIGURES}

1. Total fruit harvest distribution per production system for 2011 season. All treatments were planted on May $31^{\text {st }}$.

2. Total fruit harvested per production system for 2012 season. The high, low and 76 control treatments were planted on May $16^{\text {th }}$, May $25 / 26^{\text {th }}$, and June $8 / 9$ respectively.

3. Average total fruit production per variety within treatment. Yields represent averages across six plots, with five plants per plot. Bars represent \pm SE.

4. Marketable and cull yields per cultivar grouped by treatment for the 2012 growing season. Yields per cultivar represent average weight across six test plots containing five plants each.

5. Average percent soluble solids across all cultivars per treatment and year.

Treatment values represent average sweetness across 36 test plots and approximately 100 muskmelons. Number of melon samples differed between cultivars and years. Bars represent \pm SE.

6. Average percent soluble solids per cultivar and production system. Bars represent \pm SE.

7. High tunnel location effect on marketable yields for center and edge test plots grouped by year. Values represent average marketable yields across three test plots per location with five plants per plot.

8. Total fruit counts per treatment and year. Each treatment was planted with 180 plants per year. 
9. Total weight per treatment is compared across years.

10. Mean total fruit count across 10 replications per each pollination system. $\quad 100$ 11. Average fruit size differed significantly between years. In 2012, the screened bumble bee tunnel differed significantly from the open and open with honey bee hive pollination systems $(\mathrm{p}<0.05)$. Average fruit size is across 10 replications per each pollination system. Bars represent $\pm \mathrm{SE}$.

12. Average percent soluble solids per pollination system across 10 replications.

Pollination system $x$ year was significant $(\mathrm{p}<0.05)$. Bars represent \pm SE.

13. The first page of the survey administrated at each farmer's market.

14. The second portion of the survey consisted of a taste test between two cantaloupe samples designated as sample A and B. The same questions were used for the second sample. 


\section{Introduction}

Growers in southern New England specialize in mixed vegetable production and direct sale to consumers through farm stands and farmers' markets (USDA, 2007). Providing customers with a diverse selection of produce allows growers to compete with outside markets, including supermarkets, and encourages customer loyalty. The local food movement is driven by demand from consumers who are willing to pay more for locally-grown food. Introduction of a new crop can benefit growers financially by allowing them to charge a premium for specialty produce. Muskmelon, a staple at supermarkets, is not commonly grown in New England because of its growing requirements. The cultivars used for commercial production perform well in the hot, dry growing environments of California, Arizona, and Colorado. For local muskmelon production in southern New England, it is important to test cultivars suitable for a cooler, shorter growing season. Exploring consumer preference of these cool-season cultivars would give growers the information needed for successful production and marketing.

Open field production is the common production system for growing muskmelons in southern New England. This system consists of direct seeding or transplanting into bare soil or beds covered in black plastic mulch once soil temperatures reach 55 degrees Fahrenheit. Under open field production, growers can be limited by weather negatively affecting field conditions. A cool spring may delay planting into mid-June, or reduce plant vigor of a newly planted crop. Open field production makes the crop vulnerable to wind, and other detrimental weather 
conditions. Also, growers must be diligent with weed control and scouting of insect pests and diseases in order to produce a marketable crop. This can be challenging for the organic grower in particular because certain cultural practices and pest management options may not provide adequate control under this system.

These production issues can be remedied by use of tunnel production systems, which provide muskmelon the enhanced, protected environment a warm-season vegetable requires. Earlier or extended planting is a valuable benefit with the incorporation of tunnel production systems as well. Additionally, covered cultivation may reduce disease and insect pest pressure, and in turn reduce pesticide use (Jett, 2006b).

Tunnel production systems consist of both low and high tunnels. Low tunnels are constructed of wire hoops covered in plastic or spunbonded fabric and usually cover one planting row. As the name implies, low tunnels are limited in height and are only as tall as the crop requires. High tunnels are hoop house-like structures that are situated over several planting rows and allow for ease of access for growers and equipment.

High tunnels have been documented to pose navigation and crop access issues for pollinators (Jett, 2006b; James and Pitts-Singer, 2008). Muskmelon is dependent on bee pollination; therefore, it is important to explore this issue. Low tunnels do not have pollinator access issues since covers are removed to allow for pollination. Another issue with tunnel production systems is the initial increased costs for supplies and installation labor. This may negatively affect the grower's ability to compete with 
outside markets since production costs can vary greatly when comparing large-scale to small-scale production.

An important and unique objective of this study is to investigate consumer preference and willingness to pay for locally-grown muskmelons. This would provide growers with valuable information and provide insight into whether consumers would consider purchasing local melons at a premium price when compared to supermarket melons.

The objectives of this study were:

(1) To test muskmelon cultivars suitable for growing in southern New England in both high and low tunnel systems using organic farming methods.

(2) To explore challenges that may limit muskmelon production in high tunnels such as pollinator access.

(3) To investigate consumer preference and willingness to pay for locally-grown muskmelon. 


\section{REVIEW OF LITERATURE}

\section{Traditional Field Production:}

According to historical census information from the U.S. Department of Agriculture (USDA), muskmelon was not a widely produced crop in Rhode Island, Massachusetts, and Connecticut during the twentieth century (USDA Historical). Sweet corn, squash, cabbage, and tomato production dominated the vegetable market in these states. The growing requirements needed by a warm-season vegetable such as muskmelon are the likely reason for small-scale production in New England. Muskmelon requires soil temperatures to be at least 13 degrees Celsius for planting and successful crop establishment with optimal seasonal air temperature of 24 to 30 degrees Celsius (Howell and Hazzard, 2010). The introduction of plastics into agricultural production during the mid-twentieth century enabled growers to increase production of warm-season vegetables like muskmelons because of the plastics ability to enhance the growing environment (Lamont, 2005; Wells and Loy, 1993). Plastics modified the growing environment by creating optimal conditions that encouraged vigorous stand establishment (Orzolek, 1996).

In New England, raised beds are a common vegetable production technique used to improve soil drainage and encourage early soil warming. The use of black plastic mulches to further increase soil temperatures greatly improved crop establishment and supported early marketable yields of muskmelon (Clarkson and 
Frazier, 1957; Bonanno and Lamont, 1987; Loy and Wells, 1975). Clarkson and Frazier (1957) tested this technology by seeding the muskmelon cultivar 'Granite State' under traditional black paper mulch, newly introduced black plastic mulch and plastic caps in combination with black paper mulch in the Willamette Valley in Oregon, a region which remains cool during the growing season (average daily temperatures during the time of study ranged from 15-19 degrees Celsius). Vine growth of 'Granite State' grown in black plastic mulch was noted as "extremely vigorous', and this vigorous growth led to more fruit-bearing flowers resulting in increased fruit set and marketable yield of fruit when compared to black paper mulch and open field production. Use of plastic caps over paper mulch allowed earlier germination, but since the caps were not ventilated, they performed best during the cooler parts of the growing season. In a study conducted in North Carolina, Bonanno and Lamont (1987) grew the cultivar 'Magnum 45' and noted that during an unseasonably cool growing season, the plastic mulch (both clear and black) kept the soil temperature in the optimal range to allow for crop vigor and increased total yields. Ibarra et al. (2001), in a study investigating growth and yield of the muskmelon cultivar 'Cruiser' in the high plains of Mexico, correlated soil temperature, not air temperature, to plant biomass and early yields. Loy and Wells (1975) reported accelerated growth of muskmelons using plastics in New Hampshire. They tested four commercial hybrids ('Maverick', 'Harper', 'Burpee', and 'Goldstar'), and two experimental hybrids ('Sweet Granite' and 'Minnesota Midget' X ‘Sweet Granite') in black plastic mulch and reported that ripening of fruit was accelerated on black plastic when compared to bare soil production. 
On average, soil temperature at the root zone in these studies was raised two to six degrees Celsius during the day and one to three degrees Celsius at night when compared to bare soil. To maximize the heating benefit of black plastic, it is important to have good contact with the soil surface to transfer the heat absorbed from the black plastic (Ham et al., 1993). Researchers explored this by investigating various plastic mulches and their effects on soil and air temperatures in Kansas. They reported that black plastic increased maximum subsoil temperatures $(10 \mathrm{~cm})$ on average 3.4 degrees Celsius, and air temperatures $5 \mathrm{~cm}$ above the black plastic was $4-5$ degrees higher than ambient air. These data were collected over a period of 13 sunny days. However, it has been reported that rain can greatly affect soil temperature regardless of mulch (Nair and Ngouajio, 2010).

Using black plastic also improved melon fruit quality by increasing fruit size, reducing rind damage, and reducing weed pressure (Clarkson and Frazier, 1957). Melons growing on plastic were less prone to rot and insect damage when compared to fruit grown on bare soil. Scahles and Scheldrake (1965) tested several types of plastic mulch with the cultivar 'Burpee' in Ithaca, New York. In their study, clear plastic provided the greatest vine growth and marketable yield benefits, with black plastic a close second. The mulches did not differ in mean fruit weight produced. The use of clear plastic creates the need to treat the soil with a pre-emergent herbicide to control weed growth; depending on the size of operation, this requirement could become costly. Since this is not necessary with black plastic mulch and the increased yield benefit and quality of fruit produced is very similar, its use has become a standard practice in the production of many warm-season vegetables (Tarara, 2000). 


\section{Row Cover/Low Tunnel Production:}

The need to protect high value crops from chilling injury and spring storms, and the desire to encourage early harvests led to the use of row covers, especially in northern climates (Wells and Loy, 1993). Row covers have long provided crops protection from adverse environmental conditions, insect pests and, in some cases, diseases. The traditional material used in the early twentieth century was paper, but plastics soon surpassed paper use. Now several cover types are available for growers. The material used to cover crops ranges from porous, opaque spunbonded fabric-like material made from polyester and polypropylene to clear plastic made from polyethylene. Low tunnels covered in polyethylene have been in production for several decades and were used as an alternative to hot tents constructed from paper (Wells and Loy, 1993). The higher cost of plastic during its introduction in the 1950s60s limited its initial use. Spunbonded fabric, a newer technology than polyethylene, has been in use over the last thirty years. Wire or plastic hoops no taller than the mature height of the crop support the covering and create a tunnel over the crop row. Low tunnels (refers to row covers as well) typically cover a crop for 2-4 weeks during the growing season (Wells and Loy, 1993). Covers are removed if the crop needs insect pollination for marketable fruit production or if the cover hinders natural

growth. Spunbonded fabric is also used as a floating row cover where it is placed directly on the crop and lifts as the crop grows. Floating row covers are not 
recommended for muskmelon production as gusty winds can cause the fabric to damage young plants (Wells and Loy, 1985).

Fabric tunnels are widely used for exclusion of insect pests and and for frost protection, while plastic tunnels are less effective at frost and insect protection but more effective at accelerating growth and harvests (Dickerson, 2004; Wells and Loy, 1985; Waterer, 1992). Fabric row covers come in different weights, which in turn determine their use. Lightweight fabric functions primarily as protection from insect pests, while heavier weight fabrics also protect crops from frost and can accelerate maturity of such crops as melons, cucumbers, potatoes, and strawberries (Bachmann, 2005). In general, heavy weight fabric row covers (50 grams/meter) have been shown to provide superior frost protection over plastic covers (Bachmann, 2005; Wells and Loy, 1993). In a report summarizing materials used for tunnel production, Wells and Loy (1993) stated that heavyweight fabric covers are commonly used for cool-season crops during cold, cloudy days and at night to protect the crop from less-than-optimum growing conditions, but because their thickness does not allow proper light transmittance for adequate growth, they are removed during the day. Light transmission through clear plastic is about 90 percent, while lightweight fabrics transmit about 80 percent. Both levels are suitable for productive plant growth (Wells and Loy, 1985). Heavyweight fabric reduces light transmission to 50 percent, which is unsuitable for productive growth of many vegetable crops.

There are several advantages to using fabric and plastic row covers in combination with black plastic mulch. Beneficial climate modification includes increased day and night air/soil temperatures that protect crops from frost and chilling 
injury, and protection from damaging winds and storms (Dickerson, 2004; Wells and Loy, 1985). Many studies have demonstrated the positive effects of fabric and plastic tunnels on microclimate modification with several warm-season crops over open field production, and all noted that the soil and air heating benefits generated dramatically increased plant growth which resulted in larger plants (Bumgarner and Verlinder, 2010; Ibarra et al., 2001; Nair and Ngouajio, 2010;Waterer, 1992, 1993), with increased flower numbers resulting in greater yields for muskmelon (Ibarra et al. 2001; Waterer, 1993), cucumber (Nair and Ngouajio, 2010) and tomatoes (Bumgarner and Verlinder, 2010). Since tunnel growing systems add to production costs, high-value vegetables like cucurbits, brassicas, and solanaceous crops are more likely to be grown with this system (Wells and Loy, 1993). As will be reviewed, these added costs are balanced by increased total, marketable and early yields, and improved quality obtained from tunnel production systems (Wells and Loy, 1985; Lamont, 2005).

Tunnels can also provide protection from insect pests. Fabric covers have become an important production tool for organic growers. A study conducted in Kentucky investigated organic management techniques of cucumber beetle in watermelon and muskmelon production. The results revealed that use of fabric row covers increased total melon weight and numbers, and vine coverage by excluding cucumber beetle damage early in the growing season (Cline et al., 2008). Cline et al. (2008) also noted that the row covers protected the crop from secondary cucumber beetle larvae damage later in the season because the covers prevented egg laying at the base of the crops. A similar study in Iowa investigated the effect of row covers on suppression of bacterial wilt (vectored by striped cucumber beetles) in muskmelon and 
found that use of fabric row covers increased yield of marketable fruit and applications of insecticides were reduced (Mueller et al., 2006). Similarly, in a study conducted in Connecticut, spunbonded row covers effectively protected specialty melons (honeydew, galia, charentais) from striped cucumber beetle damage during their early stages of growth and delayed spread of bacterial wilt (Hill, 1997).

For all these studies, the benefit of using spunbonded row covers was demonstrated by dramatically increasing total yield over uncovered plots mulched in plastic only. Wells and Loy (1985) reported similar muskmelon yield results in New Hampshire with the cultivar 'Goldstar'. Results from four growing seasons (19811984) using fabric row covers over black plastic mulch generated an average of $20 \%$ greater total yield over uncovered, black plastic mulch production. In contrast, Nair and Ngouajio (2010) found that under reduced cucumber beetle pressure there was no difference in total marketable yields with spunbonded row covers compared to uncovered test plots of organic cucumber in Michigan. Their results suggest that in warm growing seasons with low insect pest pressure, cucurbits may not need the protected and enhanced growing environment covers offer. However, if early production is a goal—especially in northern climates — then tunnel production can further benefit the grower with earlier harvests.

In an experiment on early pepper production in Saskatchewan, Canada, Waterer (1992) reported that fabric row covers provided better protection from frost than slitted plastic covers. During the night, spunbonded fabric entraps heat radiated from the soil and plants better than polyethylene because the fabric material collects a film of water that serves to insulate the tunnel from cool nighttime temperatures. 
Because plastic covers are not porous, they function more like greenhouses in trapping heat during the day, but in some regions, plastic tunnels can become overheated unless vented. Perforated and slitted plastic tunnels provide ventilation (to varying degrees), but will not exclude insect pests.

In Michigan, Nair and Ngouajio (2010) tested organic cucumber production under two different weights of fabric row covers on black plastic mulch in soil amended with and without compost. There was a significant interaction between row cover and compost on yield. The effect of both produced larger plants with increased flower counts, which allowed for increased fruit counts over mulched plots without cover and compost amendment.

Yield benefits from row cover production were not consistent across all warmseason vegetables. In West Virginia, Bumgarner and Verlinder (2010) reported varying results for bell pepper and tomato tunnel production. Bell peppers grown under fabric and slitted plastic tunnels did not provide dramatic yield benefits relative to the control (no cover with straw mulch), and tomato yields were greater under fabric, but suffered under slitted plastic production when compared to open field production. The reduced yields were attributed to excessive air temperatures generated by the plastic tunnels. Tomato and pepper flowers will drop if air temperatures in excess of 30-32 degrees Celsius are experienced for long periods (Wells and Loy, 1985). Use of tunnels did have an effect on earliness by allowing more than a two-week headstart over traditional planting dates in West Virginia for both warm-season crops; however, the researchers noted that seasonal temperature effects more so than tunnel effect could greatly influence early harvests. If the season 
remained cool, early harvests may not be obtained even with tunnel production. In an experiment conducted in British Columbia, Canada, on bell pepper production, slitted plastic tunnels did support greater total yields (Jolliffe and Gaye, 1995). The researchers reported bell peppers grown under slitted plastic on black plastic mulch increased overall absolute growth of the plants, but not marketable yields when compared to uncovered treatments mulched in black plastic.

When deciding which row cover type is best for muskmelon production, studies have varied in results with regional, cultivar, and yearly seasonal differences being highly influential on productivity. A study conducted in Connecticut found that fabric covered plots out-yielded uncovered test plots by more than double; however average fruit size — an important economic trait—was not affected. (Hill, 1997). In Oregon (Willamette Valley), Hemphill (1985) reported fruit set on muskmelon cultivar 'Goldstar' grown under both slitted and perforated plastic tunnels was greater than under fabric tunnels and open field production. However, overall yield comparisons were not statistically significant, and both plastic coverings were prone to excessive heat (> 46 degrees Celsius) which damaged plants and necessitated manual venting. Wells and Loy (1985) reported similar yield results with less than 5 percent greater yields of 'Goldstar' produced using slitted plastic tunnels compared to fabric. The slitted tunnels in this study, conducted in New Hampshire, did not need additional ventilation.

In warmer climates, when comparing fabric with plastic tunnels, fabric tunnels provided the most consistent yield benefits since plastic tunnels, especially perforated plastic, were prone to excessive heating that reduced crop vigor and overall yields 
(Hemphil and Mansour, 1986; Motsenbocker and Bonanno, 1989). In North Carolina, a tunnel production test comparing fabric, and slitted and perforated plastics was consistent in enhancing earliness, but not marketable yields, of cultivar 'Magnum 45' (Motsenbocker and Bonanno, 1989). The perforated plastic treatment was only used in one year of the study because the excessive air temperatures damaged the crop and reduced yields.

Dangerously heated air can be generated from black plastic mulch and could potentially cause plant injury. In muskmelon production studies conducted in Missouri, Jett (2006a) noted that plants could suffer death from intense heat escaping from planting holes in plastic mulch that was not tightly wrapped to the raised bed. The heat would vent out of the planting holes and kill young transplants. Orzolek (1996) noted this is a common problem in plastic mulch production of peppers as well with "heat funnels" from black plastic mulch girdling pepper stems.

In cooler climates, muskmelon production studies conducted in New Hampshire with slitted plastic covers (Wells and Loy, 1985) and Canada using perforated plastic covers (Waterer, 1993; Wiebe, 1973) reported that tunnels generated periods of high heat ranging from 40-50 degrees Celsius, but plants did not exhibit any stress and plastics did not need additional ventilation. Wells and Loy (1985) successfully grew cultivar 'Goldstar' under slitted plastic without additional venting and noted its reduced labor benefit when compared to the California tunnel system of clipping two pieces of plastic with clothespins to wire hoops to allow for a top vent. This system constantly needed attention because wind would remove the covers and the tunnels needed closing at night. 
In Saskatchewan, Canada, Waterer (1993) compared perforated plastic to fabric tunnel production of muskmelon cultivar 'Earlisweet'. Even though the air temperature in the perforated tunnels exceeded 45 degrees Celsius (with a maximum recording of 50 degrees Celsius), plants did not exhibit stress. Perforated plastic tunnels usually out-yielded fabric tunnels, but yield differences were never statistically significant. In Ontario, Canada, Wiebe (1973) tested 12 cultivars of muskmelon under perforated plastic tunnels with black plastic mulch and did not need to manually ventilate. On sunny days, air temperature in the tunnels was 2-5 degrees Celsius greater than ambient air. Similar to Waterer (1993), Weibe noted that tunnel production supported early, accelerated growth and out-yielded mulched-only treatments; however, average fruit size did not vary across treatments. Additionally in Connecticut (Hill, 1997), average fruit size of specialty melons did not vary under perforated plastic when compared to plastic mulch only, or bare soil production.

The research studies for low tunnel production of muskmelon reviewed thus far have revealed a trend in regional and seasonal effects. To summarize these trends, studies found that marketable yields were not always consistent in plastic tunnel production, but total and early yields were usually higher than for fabric and open field production, especially in northern climates (Hill, 1997; Ibarra et al., 2001; Wells and Loy, 1985; Waterer, 1993). In northern climates, it is clear that early (May planting) muskmelon production using low tunnels encouraged accelerated growth and flowering (Hemphill, 1985; Hill, 1997; Waterer, 1992, 1993; Wells and Loy, 1985), whereas in warmer climates researchers reported that early planting dates contributed 
to early harvests more than effect of row covers (Bonanno and Lamont, 1987;

Bumgarner and Verlinden, 2010; Hemphill, 1985).

\section{High Tunnel/Hoophouse Production:}

A major challenge to low tunnel production is the reduced access to the crop. Crop management practices such as pest and weed control are compromised while the crop is under cover, and covers must eventually be removed for pesticide application, pollination, and continued unhindered growth (Dickerson, 2004). High tunnels, also commonly called hoophouses and unheated greenhouses, expand on the concept of low tunnel production by increasing coverage of the protected growing area and allowing walk-in access to the tunnel. Structurally, high tunnels are simple, walkthrough, metal/plastic pipe-framed houses wrapped in greenhouse-grade polyethylene and anchored to the soil. Their main function is to warm the soil for early and later planting, and provide protection from adverse weather (Wells and Loy, 1993). If needed, high tunnels can be moved — with some effort—-for use in another field. Similar to low tunnels, climate control is limited. Unlike traditional greenhouses, which are usually equipped with sophisticated climate controls, high tunnels are not automated and are instead passively heated by solar radiation. Depending on the tunnel design, vents in the form of roll-up sides provide passive ventilation. High tunnel production is valuable to growers because in both cool and warm climates growers are able to increase production of a variety of high-value crops, and garner a 
premium price from earlier availability and improved quality when compared to open field production (Lamont, 2009).

High tunnel production has long been popular in Europe, Asia and the Middle East with cucumber, tomato, pepper, and melons being the most widely produced crops (Lamont, 2009). In the United States, unheated greenhouses/high tunnels were commonly used for overwintering nursery crops with very few tunnels used for vegetable production (Wells and Loy, 1993). Beginning in the 1990s, high tunnels began gaining popularity in the northeast as a means for extending the growing season later into the fall and earlier in the spring (Wells and Loy, 1993). Common to both low and high tunnel production systems is increased labor demand. Two studies evaluating high tunnel production practices of growers in the northeast (Blomgren and Frisch, 2007) and Michigan (Connor et al., 2010) noted that in order to maximize earliness for many crops transplants are recommended, and if possible, plants should be trellised to maximize growing space. These cultural practices increase labor compared to traditional field production. Growing crops and cultivars best suited to tunnel production would help reduce labor and increase financial benefit (Giacomelli, 2009; Knewtson et al., 2010).

Choosing a tunnel design that best suits the grower's needs and climate is the first step to successful production. There are many tunnel designs used worldwide. In the United States, two common designs are the Quonset- and Gothic-styled tunnels. Quonset-styled tunnels are half-dome shaped tunnels with roll-up side vents and builtin end walls. Gothic-styled tunnels are similar in structure to Quonset, but have an arched roof and greater side height because of increased height from anchoring legs. 
Also, the increased roof slope readily sheds snow and allows for greater light transmission, and moisture control (Blomgren and Frisch, 2007; Giacomelli, 2009). Most tunnels have side vents, and (removable) end walls are also commonly equipped with vents; less common are ridge vents.

Proper venting is crucial to crop success, and without automated ventilation, is a major labor challenge, especially during periods of sunny weather (Wells, 1991). Tunnels vary in width and especially length. As width increases, control of temperature and humidity for optimal crop conditions decreases (Giacomelli, 2009; Wells, 1991). Wells and Loy (1993) stated any tunnel greater than six meters in width could suffer from poor ventilation when outside temperatures exceed 30 degrees Celsius. Length, they noted, should not affect ventilation. This is in contrast to Giacomelli's (2009) statement of length being important because of distance to (vented) end walls, which affect air circulation. In upstate New York, Wien (2009) measured environmental variation within a $38 \times 9$ meter Gothic high tunnel (4.8 meter height), a common size for commercial production, and reported the greater the ventilation within the high tunnels, the less temperature and humidity differential from ambient conditions.

In Connecticut, Gent (1991) noted that on sunny days in April tunnel air temperatures quickly increased to 35 degrees $\mathrm{C}$ before noon. Ventilating the tunnel allowed for temperatures to decrease to the optimal growing range for tomatoes (21-24 degrees C). Increased ventilation improves air circulation and decreases humidity, which decreases disease incidence, and prevents excessive growth (Blomgren and Frisch, 2007; Both et al., 2007). Venting for tunnels that are multi-cropped adds an 
additional challenge. In Saskatchewan, Canada, Waterer (2003) grew tomatoes, muskmelon, and bell peppers in a Quonset high tunnel measuring 4.3 X 29 meters (2.5 meters in height), and concluded that even though the cropping system consisted of warm-season vegetables, ventilating the tunnel to suit each crop's optimal growing environment proved challenging.

There are several crops that are well suited for high tunnel production in the United States. In New England, researchers began testing high tunnel use as an additional tool for growers to diversify cropping options and extend the growing season. Comparing low tunnel (fabric) and high tunnel production, Gent (1991) experimented with the indeterminate tomato 'New Girl' and sweet pepper production in Connecticut. The high tunnel system accelerated growth and ripening for tomatoes over fabric low tunnels and open field production. With sweet peppers both tunnel systems affected ripening about the same, but still two weeks before open field production. A mid-April to early May planting was found to be best for tomato production in Connecticut. This allowed for earlier harvests by about 3-4 weeks, and increased yields due to the extended production and decreased disease pressure. This study demonstrated that high tunnel production had great potential for providing early, quality tomatoes for local markets in New England. Wells and Sciabarrasi (1992) experimented with early high tunnel planting of determinate tomatoes in New Hampshire. Even though plant yields were less than optimal, early yields would allow growers a lucrative marketing advantage. Wells and Loy (1993) emphasized that high tunnel production could prove to be an important marketing tool for growers in New 
England and other regions in the United States where direct-to-consumer markets (e.g., farm stands and farmers' markets) play an important role.

Common crops produced in the northeast include warm and cool season vegetables, cut flowers (annual and perennial), herbs, and small fruit (Carey et al., 2009). Tomato production is the most important use of high tunnels in the United States, and worldwide (Lamont, 2009). Research studies have demonstrated an exceptional effect on earliness, yield, and quality of several tomato cultivars produced in high tunnels when compared to open field production. In Saskatchewan, Canada, Waterer (2003) evaluated tomato production in high and low tunnels with cultivars 'Roadside Red' and 'Spitfire'. He reported that high tunnels substantially out-yielded low tunnel production due to the high tunnels' superior season extension capability. Over the span of the experiment, marketable fruit production in the high tunnels was 47 percent greater than low tunnel production; however, total fruit production and quality (taste and appearance) were comparable for the two tunnel systems. A survey of six northeast growers conducted by Blomgren and Frisch (2007) revealed that five out of the six growers dedicated high tunnel acreage to tomatoes. All reported earlier yields (by 2-4 weeks dependent on cultivar and growing season), improved quality, and extended harvests, which customers appreciated.

Cucurbits - melons, cucumbers, and squash - are another group of warmseason vegetables that are widely produced in high tunnels, especially outside the United States (Lamont, 2009). In Utah, Drost (2011) reported that summer squash and tomatoes occupying the same high tunnel complemented each other nicely, and that summer squash were harvested four to six weeks earlier than field production. In 
Saskatchewan, Canada, Waterer (2003) experimented with multi-cropped high tunnels planted with tomato, pepper, and muskmelon and reported the three crops did not compliment each other's optimal growing requirements; the muskmelon vines were not trellised making them prone to trample damage. As referenced earlier, this study compared high tunnel production of the same crops to low tunnel production. To summarize the muskmelon results (cultivar Earligold'), Waterer (2003) reported that high tunnel production produced 59 percent greater yields over low tunnel production during the span of the three-year experiment. Fruit in the high tunnels matured twothree weeks earlier than low tunnel fruit during cool growing seasons; however, warm growing seasons produced equal yields of marketable fruit in the tunnel treatments. Fruit quality (flavor and sugar content) did not differ between tunnel treatments, but average fruit size within the high tunnels was larger than field production (low and uncovered treatments). Based on the results of this experiment, Waterer concluded that cultivars better suited to a longer grower season versus a cooler, shorter growing season may provide greater yields in the warm environment and extended season of high tunnel production.

Jett (2006a) tested several cultivars of muskmelon for high tunnel production in Missouri. To maximize space and allow for easier integration of mixed crop production, the melons were trellised at double field density. Similar to Waterer (2003), larger melons were also produced in the high tunnel than in field production. Because of increased vine growth within the tunnels, trellised vines should be pruned for proper crop management. Pruning increases average fruit size while decreasing number of cull fruit (Jett, 2006a). Jett (2006a) also reported that poor pollination can 
result in smaller fruit, and possibly decrease production of marketable fruit. Tunnel production, in particular high tunnels, can pose pollination challenges to crops dependent on bees for successful pollination by reducing bee access to the flowers (Dag and Eisikowitch 1999). For high yields and fruit quality, muskmelon is dependent on bee pollination (McGregor et al. 1965; Mussen and Thorp, Publication 7224). Ventilation can improve bee access to high tunnel crops. Quonset-styled tunnels that may or may not have side ventilation pose mortality and navigation problems for honey bees because lack of ventilation can entrap bees and the plastic covering may interfere with the bees' navigation mechanism (James and Pitts-Singer 2008).

Another study conducted in Missouri investigated Galia-type muskmelon production within high tunnels (Jett, 2006b). Fruit quality was excellent with an average sweetness of 14 percent soluble solids content (eligible for USDA fancy grade). Transplant and seeded production were compared with transplants producing an average of 2.5 melons per plant versus seeded plants producing an average 1.55 melons per plant. Early yields produced by the high tunnels differed between years from open field production. In year one, early yields consisted of 20-25 percent of total yields while in year two, early yields comprised 50 percent of total yields when compared to field production. As reported by other researchers studying tunnel systems, yearly seasonal conditions had a greater effect on earliness than the high tunnel environment (Jett, 2006b).

High tunnel production is becoming increasingly popular as local demand for fresh, quality produce increases (Carey et al., 2009; Lamont, 2005). Surveys of 
growers who have incorporated high tunnel production into their marketing strategy revealed single crop production within high tunnels was nonexistent, and that growers are interested in research on cropping systems/strategies and variety trials within high tunnels (Carey et al., 2009; Knewtson et al., 2010).

\section{Consumer Preference for Local Produce:}

In addition to serving grower demand for research on local production systems, this study also sought to explore consumer preference and willingness to pay for locally-grown muskmelons. Research studies investigating consumer preferences, purchasing habits, and perception of fresh produce helps growers make informed production decisions and market effectively (Lusk and Hudson, 2004).

Obtaining customer loyalty is key to any successful marketing campaign. Before the local food movement of the twenty-first century, broad-scale campaigns to support agricultural production and local food producers at the state level promoted brand recognition and consumer loyalty. Termed state-branding programs, "Jersey Fresh" was one of the first of its kind and is a successful example of promoting agricultural products produced within New Jersey (Patterson, 2006). Effective promotion of the state brand can greatly influence consumer-purchasing habits, as Giraud et al. (2005) highlighted in a study exploring state brand loyalty amongst the northern New England states. Maine (Maine Made: America's Best) and Vermont's (Vermont's Seal of Quality) well-established and state-funded branding programs were recognized by respondents of the survey as quality food products (primarily lobster and maple syrup) worth more than out-of-state food products. New 
Hampshire's branding program—not state initiated or funded—was lesser-known and evident from less supportive responses (Giraud et al., 2005). The state brand "Arizona Grown" has not been widely acknowledged by Arizona residents and hence did not gain the same following and benefits as the "Jersey Fresh" program (Patterson and Cardona-Martinez, 2004). Surveys conducted by Jekanowski et al. (2000) and Patterson and Cardona-Martinez (2004) revealed that customer loyalty to state brands increased with length of residency within that state, and that perception of quality was found to have the greatest influence on purchase. Eastwood et al. (1987) explored consumer preference for local fresh vegetables and fruits in Tennessee to that of outof-state fresh produce. From the produce tested, tomatoes and peaches had the greatest market potential for a local single-product marketing campaign. Respondents expressed concern over quality and price with expectations that both attributes must be comparable to out-of-state produce.

State-branding programs are not always perceived as benefitting the resident or being economically beneficial to the grower. Consumers have expressed concern that high-quality produce shipped out-of-state to sell at a greater profit leaves residents with lesser-quality local produce to purchase (Patterson, 2006). Patterson (2006) argued that even if state-branding programs increased demand for local, fresh produce, increased profit for growers might not result because without an increase in price, production would not expand. Patterson (2006) also argued that state-branding programs do not effectively celebrate the diversity of farm production within the state, but instead are more likely to focus on one crop, like Maine potatoes or Florida citrus. Localizing sales and utilizing direct market options would better aid grower profits. 
Direct market channels, e.g., farmers' markets and farm stands, better serve local and small farm production of fresh produce (Darby et al., 2008).

Local markets have been broadly defined due to inherent differences in state size. Darby et al. (2008) concluded that since respondents did not distinguish between "grown nearby" and "grown in Ohio" then the state boundary of Ohio, and possibly other similar-sized states, would serve to define local fresh market production. However, the same conclusion may not apply to California or regions with smaller states like New England. Martinez et al. (2010) expanded on this definition to also define local production as a 400-mile radius for smaller states. Several studies have shown that food products labeled as locally grown are usually valued more than the same food product produced outside the state/region. Carpio and Isengildina-Massa (2009) conducted a phone survey of South Carolina residents and learned that 78 percent believed that food products produced in-state were of equal or better quality than food products from other states. Individuals who perceived higher quality were willing to pay an 11 percent premium for locally produced South Carolina food products. Overall, the results revealed a difference between consumers who frequent farmers' markets and those who did not. Consumers who attended farmers' markets at least once during the year stated they would be willing to pay an additional 6.1 percent premium for local produce.

Darby et al. (2006) surveyed customers at both farmers' markets and supermarkets in Ohio on their shopping habits and motivation to choose locally produced foods. Overall, respondents stated freshness (91 percent) as the overwhelming reason to purchase local food products. Support for local business and 
taste also ranked high. Individuals surveyed at supermarkets stated that taste/quality (based on prior experience) affected their purchasing habits more so than price, though supermarket shoppers were more sensitive to price fluctuations than direct market shoppers. Mayen and Marshall (2005) tested consumer preference for fresh-cut melons (including muskmelons) as a potential value-added food product for Indiana melon growers. Their survey, conducted in produce departments at grocery stores, revealed that customers valued fresh-cut melon from local melons the same as national brands and that if a local brand were introduced, it could potentially capture 44 percent of the market share. In Ohio, researchers conducted a survey asking shoppers at both farmers' markets and grocery stores to choose between local fresh strawberries and national fresh strawberries (by image only) (Darby et al., 2008). Both types of shoppers valued the local strawberries more than the national brand, though farmers' markets respondents were willing to pay twice as much more per strawberry basket than grocery store shoppers.

Consumers surveyed at grocery stores in Kentucky showed a stronger response to blueberry products labeled as local than to products labelled organic. Food products labeled as local or local and organic were rated high, but local was valued more than organic alone (Hu et al., 2009). Bond et al. (2006) conducted a national survey soliciting data on purchasing habits of fresh produce, with an emphasis on produce purchased from direct markets. They found that the most important attributes drawing customers to direct markets were pesticide-free production and access to locally-grown produce. Interestingly, organic production was not equated with pesticide-free production, as it ranked second to last in the attributes listed. 
Consumers valued "locally grown by family farms" more so than "locally grown and organic." Other attributes that were ranked above organic were firmness and texture, freshness, and color and visual appeal. A majority (66 percent) of farmers' markets customers surveyed in New Jersey stated that even though organic produce was available at their farmers' markets they seldom purchased it (Govindasamy et al., 2002). In Kansas, Whorton (2009) found socio-economic characteristics did not prove to affect purchase of local produce, but did affect purchase of organic produce. Gender (female), increasing household size, and higher education were common shared characteristics of consumers of organic produce. Williams and Hammitt (2000) found that consumers of organic fresh produce in the Boston area were more likely to be middle-aged and have a larger household than consumers of conventional fresh produce.

Farmers' markets play a major role in increasing profits for local growers, and are especially crucial to the survival of small farms (Darby et al., 2008). As demand for local fresh produce increases, so do the number of farmers' markets in the United States (Hu et al., 2012; Martinez et al., 2010). From 1994 to 2010, the number of farmers' markets in the United States more than tripled from 1,775 to 6,132 (Hu et al., 2012). In Rhode Island in 2011 there were 45 farmers' markets, which is double the number from 2006 (FarmFreshRI). Consumers appreciate the diversity and freshness of produce offered at farmers' market and believe their purchases help boost local agricultural production and local economies (Govindasamy et al., 2002).

Studies investigating hypothetical willingness to pay have been criticized for the accuracy of results collected. A common reaction to hypothetical willingness-to- 
pay studies is the question of whether or not respondents' stated monetary amounts and preferences are an accurate representation of their behavior/attitude if the good were made available. Surveys eliciting willingness-to-pay information, also referred to as the contingent valuation method, are a common tool to gather consumer information. Dickie at al. (1987) stated that when evaluating hypothetical demand data, researchers should address sources of potential bias that may taint respondents' decision-making. Sources of bias could be language used for the survey introduction and/or questions, or personal biases exercised by the respondents (Ajzen et al., 1996). Environmental or public goods are potential sources of bias since they can elicit altruistic feelings and cause respondents to overstate value (Ajzen at al., 1996). Carlsson and Martinson (2001) compared hypothetical and actual marginal willingness-to-pay data for an environmental good. Using the discrete choice method, respondents were asked to state their preference (by choosing from given choices) on various environmental projects (preservation projects), and then asked to donate to a randomly selected environmental project from the list offered. Their results revealed no difference in hypothetical and actual preferences; however the researchers noted that respondents may benefit from "warm-up questions" since there was evidence of instability of preferences within the hypothetical experiment. To compare hypothetical demand with actual demand for a private good, Dickie at al. (1987) used strawberries (a well-known private good) to collect actual and hypothetical willingness-to-pay data. In a door-to-door survey, the researchers either pretended to sell strawberries or presented themselves as researchers and asked respondents to state the quantity (i.e., the volume) of strawberries expected at a given price. The latter approach was 
expected to eliminate "payment bias." The results suggested actual and hypothetical demand to be statistically similar after "cleaning" the data. Actual demand was more variable than hypothetical demand data.

A method used to decrease or remove potential bias is to introduce a technique referred to as "cheap talk." Cheap talk refers to an explanatory statement that is meant to discourage individual bias, but not influence decision-making. Both Aadland and Caplan (2003), and Lusk (2003) found that including a "cheap talk" statement was effective at diminishing hypothetical bias for a public (curb-side recycling) and private (golden rice) good. Lusk (2003) and List et al. (2006) both found that knowledgeable individuals (those familiar with the good) may be immune or disregard cheap-talk statements, thus creating potential outliers. Careful survey development, sampling, and analysis can also serve to mitigate hypothetical bias. 


\section{Chapter 2}

Chapter 2 has been formatted for submission to HortScience.

\section{A Comparative Analysis of Tunnel Production Systems for Muskmelon in Rhode}

\section{Island}

Mina Vescera

Masters Candidate, Department of Plant Sciences and Entomology, University of Rhode Island, Kingston, RI 02881. Email: mina.vescera@gmail.com

Rebecca Nelson Brown ${ }^{1}$

Associate Professor, Department of Plant Sciences and Entomology, University of Rhode Island, Kingston, RI, 02881. Email: Brownreb@uri.edu

\footnotetext{
${ }^{1}$ Corresponding author and for reprints email Rebecca N. Brown: Brownreb@uri.edu
} 


\section{Introduction:}

Small-scale production (grossing $<\$ 250,000$ annually) is the dominant farming system in New England (NASS, 2009). Farmers in New England specialize in diversifying their production to meet local demand for fresh produce, and in turn greatly benefit from direct-to-consumer sales (Sassenrath et al., 2010). Plasticulture technology (e.g., high and low tunnels) has enabled farmers in New England to extend production beyond the traditional growing season and meet customer demand for fresh, local produce for most or all of the year. The purpose of this study was to investigate muskmelon (Cucumis melo L. var. reticulates) tunnel production systems for southern New England growers as a new warm-season crop for local markets.

Hendrickson et al. (2008) posit that diversifying farming operations increases production sustainability. They claim that with dynamic agricultural production systems, sustainability (encompassing economic, environmental and social aspects) increases because diverse operations have greater adaptability to market changes, and small-scale growers are more sensitive to community expectations. One way for farmers to diversify and respond to community expectations is to use season-extension methods. Plasticulture is becoming the standard production tool used to extend the growing season. Lamont (1996) defines plasticulture as the use of plastics within cropping systems to improve overall production. Within the last 15 years it has become an important tool growers use in New England to diversify their production by supporting production of crops such as muskmelon that traditionally would not thrive in open field production. Tunnel production systems and use of drip irrigation and 
black mulch are cultural practices that allow growers to maximize production and profits while reducing costly farm inputs such as pesticides and fertilizers (Wells and Loy, 1993). For several crops, tunnel production has been shown to produce earlier and overall greater yields with improved quality when compared to open field production (Lamont, 2005). The added costs of plasticulture technology are recovered through these benefits.

Muskmelons are heat-loving and respond well to plasticulture and tunnel systems. In low tunnel studies conducted both in climates with warm and cool summers, tunnels increased earliness by accelerating flowering and increased fruit set which resulted in greater yields over open field production (Bonnano and Lamont, 1989; Hemphill, 1985; Motsenbocker and Bonanno, 1989; Wiebe, 1973). In New Hampshire, Loy and Wells (1975) tested commercial hybrids and open-pollinated varieties of muskmelon under plastic tunnels in black mulch. The low tunnels encouraged earlier flowering with increased yields and quality over open field production, but fruit of commercial hybrids tested took longer to ripen than openpollinated cultivars. High tunnel muskmelon production tests have demonstrated similar yield and quality benefits. In Saskatchewan, Canada, Wateter (2003) compared high and low tunnel production of muskmelons and reported that high tunnels produced an earlier crop and greater total yields than low tunnels. Melons grown in high tunnels were larger than those grown in the open field, but quality (flavor and sugar) did not differ between treatments. Jett (2006a) tested several cultivars of muskmelon and watermelon for high tunnel production in Missouri. The enhanced growing environment of the tunnel allowed for earlier planting and 
decreased pressure from insect pests, which reduced insecticide use. Similar to Waterer (2003), melons grown in high tunnels were larger than field melons.

Loy and Wells (1975) and Jett (2006) expressed the need to test cultivars for suitability to tunnel production systems as performance may vary. It is important to test crop production systems in several geographic regions to measure response to local growing conditions (Carey et al., 2009; Knewtson et al., 2010; Wells and Loy, 1993).

The primary objective of this research was to evaluate muskmelon production in southern New England using high and low tunnel systems. Cultivars suitable for the region were examined for earliness, yield and quality response to each tunnel system. Within the high tunnels, yield response to location effect between center and edge rows was also explored.

\section{Methods:}

Research Site: Research was conducted during the 2011 and 2012 growing seasons at the University of Rhode Island Greene H. Gardener Agricultural Experiment Station (Kingston, RI). Soil type is Bridgehampton and Enfield silt loam.

General Production Methods: Air and soil temperatures were recorded with Thermochron iButtons (Lawrenceburg, KY, USA) at $20 \mathrm{~cm}$ height for air, and a $10 \mathrm{~cm}$ depth for soil. Temperature sensors were located within planting rows at the center of each treatment. Open field air and soil (without mulch) temperatures were recorded as well for comparison. Humidity was measured using LogTag data recorders

(Contoocook, NH, USA) at 1.7 meters for the high tunnel and 0.28 meter for the low 
tunnel and control treatments. In 2011, some soil and air temperature data loggers in the field treatments (iButtons) were damaged by water and the data were lost. To avoid this problem in 2012, soil data loggers were placed in small plastic vials filled with sand and capped. Air data loggers were sheltered from rain using funnels similar to those used in Hubbard (2011).

Greenhouse-grown seedlings were used for all treatments and fertilized with fish emulsion twice before setting out to harden off for five days. Seeding and transplant dates for each year and treatment are shown in table 1. Due to a gummy stem blight outbreak during the 2011 season, all seed in 2012 was imbibed in a solution of 0.0148 percent thiram at a rate of $0.5 \mathrm{ml}$ of solution per seed to reduce the chances of seed-borne inoculum causing another outbreak. To further prevent gummy stem blight, all plants were treated with applications of Regalia SC, a biofungicide containing extract of Reynoutria sachalinensis (Marrone Bio Innovations, Davis, CA.).

Organic nutrient management followed recommendations from soil test results and guidelines from the New England Vegetable Management Guide (Howell and Hazard, 2010. Organic fertilizer (Pro-Gro 5-3-4, North Country Organics, Bedford,VT) was applied during bed construction with a nitrogen rate of $56 \mathrm{~kg} / \mathrm{ha}$. Tissue sampling was conducted approximately five weeks after transplanting. One line of drip irrigation was placed under mulched beds. In 2011 0.6-mil biodegradable plastic mulch (BioTelo) was used for the low tunnel and control treatments, with 1-mil black embossed polyethylene used in the high tunnels. In 2012, all treatments were mulched with 1-mil black embossed polyethylene to discourage rind damage from 
striped cucumber beetle larvae (Acalymma vittatum). In 2011 the field plantings were covered with Agribon-15 insect barrier until flowering for protection from striped cucumber beetles. Beds were not covered in the high tunnel because all plants had at least five true leaves when beetles emerged. In 2012 the Agribon-15 was replaced with ProtekNet (Dubois Agrinovation, Quebac, Canada), which provided similar levels of insect protection with less heat build-up and better light penetration. Once a majority of plants were flowering, covers were removed. To control for striped cucumber beetles after removal of covers, pyrethrin (Pyganic EC) was applied at a rate of $15 \mathrm{ml} / 3.78$ liters once threshold was met ( 1 beetle per 2 plants). Plants were fertigated every seven to ten days with fish emulsion at a rate of 47 liters/ha and irrigated at a rate of $2.54 \mathrm{~cm} /$ week. Treatments were scouted weekly for insect pests and diseases. Honey bees were provided to ensure pollination for field and high tunnel treatments. Once melons were ripe, harvesting was done every other day. Most fruit was harvested at full-slip, except cv. 'Sivan', which was harvested at halfslip

High Tunnels: Plots for the high tunnel treatment were located within three Gothicstyle tunnels each measuring $22 \times 6$ meters with $1.2 \mathrm{~m}$ sidewalls and a height of $4 \mathrm{~m}$ at the peak. The tunnels were arranged in an east-west orientation with $3 \mathrm{~m}$ between tunnels and were covered with a single layer of 6-mil (0.153-mm), 4-year Tufflite IV greenhouse polyethylene (Berry Plastics Corp., Evansville, IN). Planting rows, measuring $11.43 \mathrm{~m}$, were oriented east to west with two rows occupying the interior and two rows occupying the outer edges for a total of four rows per tunnel. Test plots 
(five per row with two buffer plots) were centered in the high tunnels and measured $0.8 \times 2.3$ meters with 0.46 meter in-row spacing.

Ventilation was provided by 1.2-meter roll-up vents on each side and by a solar automated 0.5-meter roll-up ridge vent (Nolt's Produce Supplies, Leola, PA). Removable endwalls covered in polyethylene were constructed after the Penn State high tunnel design to allow for unobstructed passage of equipment if needed (Lamont et al., 2002). Once vines started to run, a simple trellis consisting of sisal twine, rebar, and orchard wire supported the vines and fruit. For the high tunnels, the automated ridge vent was set to open at 18 degrees Celsius. Side vents were manually vented until nighttime temperatures were above 15 degrees Celsius; thereafter vents and the doorway remained open, however endwalls remained in place.

Low Tunnels: Low tunnels were constructed with galvanized wire hoops (0.6 meter height) and covered with perforated (2011) or slitted (2012) clear 1-mil, and 0.8-mil plastic, respectively. A total of six tunnels, measuring $18.29 \mathrm{~m}$, were constructed with one cultivar test plot per tunnel. Test plots for field treatments (including control) measured $0.76 \times 3.05 \mathrm{~m}$. In-row spacing was $0.61 \mathrm{~m}$. Buffer plots were placed at the beginning and end of each field row. On sunny days, perforated tunnels were vented during the day and closed in the evening.

Cultivars: In 2011 five hybrid muskmelon cultivars ('Athena', 'Lil Loupe', 'Sarah’s Choice', and 'Sivan'), and one open pollinated variety ('Sweet Granite') were selected for their earliness and small fruit size. Small fruit size was important since vines would be trellised. Average fruit size (according to seed company data) ranged from $0.68 \mathrm{~kg}$ to $2.72 \mathrm{~kg}$, and days to maturity ranged from 70-85 days. In 2012, 'Sweet 
Granite' was replaced with cv. 'Earlichamp' since in 2011 'Sweet Granite' was a failed crop. Thirty plants per cultivar per treatment were used, with a treatment total of 180. Extra plantings were used in buffer plots at the ends of each planting row.

Experimental Design and Response Variables: The experimental design was a randomized complete block design with three treatments and one blocking factor (tunnel). Test plots containing five plants per cultivar were replicated six times per treatment and randomly assigned within planting rows.

Several measurements were recorded to evaluate tunnel response per cultivar. Earliness was measured by comparing first day of harvest, distribution of harvest over time, and peak harvest dates between cultivars and treatments. Total fruit weight and number per plot were recorded, with cull and marketable fruit data recorded as well. Cull and marketable fruit were determined by size and appearance. Fruit quality was measured by both marketable yields and percent soluble solids (sweetness). Soluble solids were measured with a hand-held refractometer following MacGillivray (1947). The first 6-18 fruit (dependent on cultivar) to ripen in each plot were used for soluble solids testing. The ground-touching or lower portion of the melon was marked. The melon was halved with measurements taken from the noted lower half. Depending on melon size, 3-6 juice subsamples were used to determine average sweetness per fruit. Nine percent average soluble solids content and above was considered acceptable (Agricultural Marketing Services, 2008). 
2012: Planting dates differed between years. In 2011, the high and low tunnel treatments were seeded within one day of each other and transplanted on the same day (May $31^{\text {st }}$ ). In 2012, the high tunnels were planted on May $16^{\text {th }}$, and the low tunnels were planted ten days later on May $25^{\text {th }}$ and $26^{\text {th }}$. The control treatment was planted on June $8^{\text {th }}$ and $9^{\text {th }}$.

The high tunnel plantings were covered with ProtekNet low tunnels because of early emergence of striped cucumber beetle; the tunnels covered the plants for 13 days (5/17-29/2012). Low tunnels were covered with ProtekNet and clear slitted plastic to allow for better ventilation, removing the need to manually ventilate. The control was covered with ProtekNet only. The low tunnel covers were removed 19 days after transplanting, and the control covers were removed 20 days after transplanting.

Statistical analyses were done using SAS (Release 9.2, 2002-2008, SAS, Cary, NC). Analysis of variance was done to test for treatment, cultivar, and year effects including interactions for all continuous data (SAS, Proc GLM). If main effects proved significant, the ANOVA procedure was performed with pairwise comparisons using Fisher's protected LSD to reveal treatment differences by cultivar and production system. Additionally, to test if percent soluble solids were correlated with fruit size, a Pearson's correlation test was done. Discrete data and low-count data were analyzed using BIOMstat for Windows (Version 3.3, Setauket, NY) to test fruit harvest distribution data with log-linear 3-way analysis. If the 3-way analysis was significant, 2-way row (fruit distribution by harvest week) by column (treatment) tests grouped by cultivar were done to distinguish differences. All tests were conducted at the $P=0.05$ significance level. 


\section{Results}

Gummy stem blight, a fungal disease caused by the pathogen Didymella bryoniae, affected all plants in 2011. The pathogen was likely seed-borne, although seed assays did not reveal the culprit. The disease negatively affected vine vigor for 'Sivan', 'Lil Loupe', and 'Tasty Bites', which then also affected overall fruit counts. 'Sweet Granite' was a failed crop in 2011 because percent soluble solids were below acceptable levels. This may have been an effect of gummy stem blight, though vines did show good resistance to the disease; however, fruit ripening may have been hastened as a result of the disease. Several plants in the low tunnel treatment were negatively affected by high temperatures in the perforated tunnels, which also were covered with Agribon-15 to provide cucumber beetle protection. Plants were not replaced as the loss was considered a treatment effect. To eliminate over-heating, manual ventilation on sunny days was necessary. 'Athena' and 'Sarah's Choice' were the most productive cultivars in 2011.

In 2012, secondary populations of striped cucumber beetle severely affected vine vigor, fruit quality and counts for several cultivars. 'Tasty Bites' was the most susceptible cultivar, and quickly declined in vine vigor as a result. 'Lil' Loupe' and 'Sivan' were also susceptible but to a lesser degree. 'Earlichamp' performed better in the high tunnel system than in the field treatments. Even though vines in the field were less vigorous than high tunnel plots, fruit production was still excellent. The three high tunnels comprising the high tunnel treatment differed in yields. The screened high tunnel used to test eastern bumble bee pollinator effectiveness became infested with aphids, severely compromising plant health. Management efforts were 
not effective. Response variables (yields and percent soluble solids) from the other two houses were averaged and used as replacement values for the compromised repetitions. Overall, 'Earlichamp' and 'Sarah's Choice' were the most productive cultivars in 2012.

\section{Earliness and fruit distribution}

First day of harvest represents the average day of first harvest from test plots for each cultivar/treatment. Fruit distribution was evaluated by comparing weekly harvest yields and peak harvests between treatments. Evaluating earliness (first harvest) and fruit distribution gives growers within southern New England an idea of how early and for how long each treatment will produce muskmelon for fresh market. Additionally, examining fruit harvest distribution within treatment is important because it reveals treatment effects on availability of the crop during the season. Since planting dates differed between years, each year was analyzed separately. Statistical models for each response variable are detailed in table-form in the appendix. 2011

Earliness: Treatment and cultivar had an effect on first day of harvest, but the interaction effect was not significant $(\mathrm{p}<0.05$ and $\mathrm{p}<0.0001$, respectively). The high tunnel treatment had the earliest first harvests, but it was not statistically different from the low tunnel treatment. The control treatment resulted in significantly later average first harvests $(\mathrm{p}<0.05)($ Table 2$)$. The difference in earliness between high tunnel and control treatments was greatest for 'Sweet Granite' at four days. 'Sweet Granite' was the first cultivar to ripen in all treatments, as shown in Table 2. Average first harvests for the other five cultivars were within two days of each other across 
treatments. Harvesting of all other cultivars began a week after the first harvest of 'Sweet Granite' in each treatment.

Fruit harvest distribution: Harvest distribution was first analyzed by examining the 3-way interaction between week $x$ treatment $x$ cultivar, and a 2-way week $\mathrm{x}$ treatment test grouped by cultivar if the 3-way was significant. Week represents the number of fruit harvested per week for cultivar by treatment. The 3-way interaction was significant $(\mathrm{p}<0.05)$, thus a treatment $\mathrm{x}$ week test of independence was conducted to further determine differences within cultivar and treatment. Harvests were conducted over a six-week period. Figure 1 displays harvest distributions by treatment. Significant interactions were found for 'Lil Loupe', 'Sivan', 'Sweet Granite', and 'Tasty Bites'. For 'Lil Loupe', the low tunnel treatment differed significantly from the high tunnel treatment $(\mathrm{p}<0.05)$, but not the control; less fruit was produced at the end of the harvest period, possibly due to stress from gummy stem blight. The control and high tunnel treatments did not differ. For 'Sivan' the high tunnel treatment differed significantly from the field treatments $(\mathrm{p}<0.0001)$. 'Sivan' took longer to ripen in the high tunnel treatment compared to low tunnel and control treatments. High tunnel 'Sweet Granite' ripened a week earlier than field treatments; the difference was significant. Fruit ripening of 'Tasty Bites' was significantly $(\mathrm{p}<0.0001)$ accelerated in the high tunnel because of gummy stem blight effects, which also caused severe vine decline thus shortening the harvest period. Peak harvest dates for all cultivars were similar across all treatments (Table 3). 2012 
Earliness: In year two, there were both treatment and cultivar effects on first harvest dates $(\mathrm{p}=<0.0001)$. The interaction effect was not significant. Seeding and planting date and genotype likely affected earliness more than production system did since the treatments were seeded and transplanted (more or less) two weeks apart from each other (Table 1). On average, harvest began seven and seventeen days earlier in the high tunnel than in the low and control treatments, respectively (Table 2).

Fruit harvest distribution: A 3-way interaction effect between week x treatment $\mathrm{x}$ cultivar affected fruit harvest distribution across all production systems $(\mathrm{p}=<0.0001)$ (Fig. 2). Since the 3-way analysis was significant, week $x$ treatment tests grouped by cultivar were conducted. The harvest period was distributed across a four-week period. 'Earlichamp', 'Sarah's Choice', and 'Tasty Bites' each had statistically similar fruit harvest distribution in the high and low tunnel treatments, but differed in the control treatment $(\mathrm{p}<0.0001)$. Control plots were most vunerable to striped cucumber beetle damage, and this likely affected fruit counts. The first two weeks of harvest for "Earlichamp" in the high and low tunnels were very similar with each having approximately 85 percent of total fruit harvested. Both 'Sarah's Choice' and 'Tasty Bites' fruit harvest distributions were similar in each treatment with fairly evenly distributed harvests, though this effect was more pronounced in the high tunnel. By the fourth week, the low tunnel fruit harvest was approximately ten percent less than the high tunnel. Athena' fruit harvest distribution did not differ in the high tunnel and control treatments, but did differ significantly from the low tunnel treatment $(\mathrm{p}<0.0001)$. Most fruit was harvested during the second week for the high tunnel and control treatment, whereas for the low tunnel treatment, the majority of 
fruit was harvested during the third week. High tunnel fruit distribution for 'Sivan' did not differ from the low tunnel and control treatments. The control and low tunnel fruit harvest distributions varied from each other $(\mathrm{p}<0.0001)$. The control treatment had fairly equal harvest distribution across the harvest period while the low tunnel treatment had more harvests during the middle of the harvest period.

Peak harvest dates were different for all three production systems (Table 3). The high tunnel treatment had the earliest peaks for most cultivars, and the control treatment had the latest by approximately five days for each cultivar after the low tunnel treatment. In the high tunnel treatment, 'Sivan' was a failed crop, and 'Sarah's Choice' had even fruit harvest distribution across the harvest period.

\section{Yield}

Fruit number, average fruit size, and total weights were analyzed. Fruit number included both marketable and cull fruit. Total, marketable and cull weights were analyzed individually across cultivars and treatments.

Fruit Number: Total fruit number per cultivar was averaged from six repetitions containing five plants per treatment. A non-parametric Wilcoxon scores test was conducted to test for differences between years. There were significant treatment differences for the high tunnel and control treatments between years in total fruit production ( $\mathrm{p}<0.05$ and $\mathrm{p}<0.0001$, respectively). For both treatments, 2011 was the more productive year. The low tunnel treatment did not differ in fruit production between years. In both years the low tunnel treatment out-produced the high and control treatments, with the high tunnel treatments producing the least amount of fruit each year (Figure 3). 
Average fruit size: Total number of fruit from across six test plots per cultivar was averaged over total weight per cultivar to obtain average fruit size per treatment. Treatment $\mathrm{x}$ cultivar $\mathrm{x}$ year was significant $(\mathrm{p}<0.05)$, with treatment $\mathrm{x}$ year differing as well $(\mathrm{p}<0.0001)$. Table 5 lists average fruit size per cultivar across treatments. Since there was a significant 3-way interaction, each year will be summarized individually.

In 2011 the high tunnel treatment produced the largest fruit, but significance varied across cultivars. 'Athena' fruit size was marginally different across treatments, with the field treatments not differing in average fruit size $(p=0.0457)$. 'Lil Loupe' produced significantly larger fruit in the high tunnel treatment, with the field treatments not differing from each other $(\mathrm{p}<0.0001)$. 'Sivan' produced larger fruit in the high tunnel when compared to the low tunnel treatment $(\mathrm{p}<0.05)$. The control treatment did not differ from the high or low tunnel treatments. 'Sarah's Choice' and 'Sweet Granite' each were largest in the high tunnel and smallest in the low tunnel treatment, though differences were not significant. 'Tasty Bites' did not differ significantly in fruit size across treatments.

In 2012 average fruit size for 'Athena', 'Sivan', 'Sarah's Choice’, $(\mathrm{p}<0.05)$ and 'Lil Loupe' and 'Tasty Bites ( $\mathrm{p}<0.0001)$ was larger in the low tunnel and control treatments, which did not differ, and smallest in the high tunnel treatment. Average fruit size for 'Earlichamp' was consistent across treatments.

Marketable yield: Fruit were classified as marketable if the rind was not bruised and size was within the cultivar's size range. Marketable weight per cultivar was obtained by the average of six test plots per treatment. Treatment $\mathrm{x}$ cultivar $\mathrm{x}$ 
year was marginally significant $(\mathrm{p}=0.0507)$. Both cultivar and treatment effects differed between years $(\mathrm{p}<0.05$ and $\mathrm{p}<0.0001$, respectively).

There were no statistically significant differences in marketable yields within cultivars across treatments in 2011. 'Athena' marketable yields were very consistent across treatments and comprised approximately 94 percent of total yields. For 'Lil Loupe", marketable yields were highest in the high tunnel and lowest in the control treatment. The high tunnel test plots produced nearly 1.5 times more marketable fruit than the control treatment. For 'Sivan', the low tunnel treatment produced 12.5 percent more marketable fruit than the high and control treatments, which produced similar marketable yields. 'Sarah's Choice' marketable yields were very similar in the high and low tunnel treatments, comprising approximately 84 percent of total yields. 'Sweet Granite' produced zero marketable field fruit, and only two percent of total yields were marketable in the high tunnel treatment. Gummy stem blight negatively affected fruit development, causing fruit to mature prematurely. For 'Tasty Bites' field treatments produced approximately 17 percent greater marketable yields per test plot than the high tunnel treatment.

Marketable yields (figure 4) differed across all cultivars in 2012 ( $\mathrm{p}<0.0001)$. Unless stated otherwise, the high tunnel and control treatments did not differ. For 'Athena', the low tunnel treatment produced nearly 2.5 times more marketable fruit than the high tunnel and control treatments, respectively $(\mathrm{p}<0.0001)$. 'Earlichamp' marketable yields in the low tunnel were significantly greater than the high tunnel and control treatment, producing 44 and 95 percent more per plot, respectively $(\mathrm{p}<0.05)$. Marketable yields for 'Lil Loupe, and 'Sarah's Choice' differed significantly across all 
treatments $(\mathrm{p}<0.0001)$. For 'Lil Loupe' the low tunnel had significantly greater marketable yields, producing more than twice as much fruit as the control and three times more than the high tunnel treatment. For 'Sivan', the low tunnel treatment outproduced the control by a factor of two and produced four times more marketable fruit per plot than the high tunnel treatment. In general, 'Sivan' does not thrive in the high tunnel environment. For 'Sarah's Choice', the low tunnel treatment produced 48 percent greater marketable yields than the control treatment, and 179 percent more than the high tunnel treatment. Marketable yields for 'Tasty Bites' in the low tunnel significantly exceeded yields in the control and high tunnel treatments by more than 110 and 210 percent, respectively.

Cull Yields: Fruit were classified as cull if misshapen, small, or rotting. There was no significant 3-way interaction. Cull yields in the various cultivars differed by treatment and between years $(\mathrm{p}<0.05$, and $\mathrm{p}<0.0001$, respectively $)$. Significant differences in cull yields within cultivars across treatments were present in 2011, but not 2012 .

Cull yield in 'Little Loupe' varied by year with significantly $(\mathrm{p}<.01)$ higher cull yields in 2011than in 2012. The control treatment produced significantly $(\mathrm{p}<.01)$ more cull yield than either the low or high tunnel treatments. In 2011, 'Athena' showed excellent resistance to gummy stem blight, with field treatments producing less than four percent cull yields. The high tunnel had ten percent cull yields. In 2012, cull yields were similar across all treatments $(\approx 10 \%)$. Since year was not significant for 'Sivan' and 'Sarah's Choice', percents represent cull yields across both years. For 'Sivan', the high tunnel produced the least cull fruit (15 percent). The low 
tunnel produced 22 percent cull yield, and the control produced 30 percent cull. For 'Sarah's Choice', the low tunnel treatment produced the lowest cull yields at ten percent. Cull yields in the high tunnel and control were 25 and 16 percent of total yields, respectively. 'Tasty Bites' was very sensitive to gummy stem blight in 2011, and striped cucumber beetles in 2012. In 2011, cull yields averaged $6.1 \mathrm{~kg}$ and were greater than 60 percent across all treatments. In 2012, cull yields averaged only $1.4 \mathrm{~kg}$ and 26 percent of total yield. There were no significant differences among treatments. In 2011, 'Sweet Granite’ produced very poor quality fruit with more 95 percent cull in the high tunnel, and 100 percent cull in the field treatments. The 2012 replacement cultivar, 'Earlichamp', had excellent resistance to striped cucumber beetle. The high tunnel and low tunnel treatment had cull yields of four and seven percent, respectively. The control treatment produced greater cull yields at 17 percent, but this was not significant.

Total yields: Total yield was measured as the total fruit weight per treatment. The 3-way interaction was not significant. Treatment $\mathrm{x}$ year was the only significant 2-way interaction.

The high tunnel treatment yielded twice as much in 2011 as in 2012. In 2011, total yields were very similar across all treatments. However, in 2012 high tunnel total yields were less than half the total production of the low tunnel treatment, but still similar to the control. The low tunnel treatment was very consistent across years for total yield, and was always the most productive treatment. 
Like the high tunnel treatment, the control treatment yielded twice as much in 2011 as in 2012. In 2012, the control treatment was planted approximately ten days later than in 2011.

\section{Percent Soluble Solids}

In melons, soluble solids consist primarily of sugars $(\approx 85 \%)$ and is correlated to sweetness. It is an important measurement of fruit quality for muskmelon since it affects flavor, and is a quality criterion for USDA standards. Percent soluble solids were measured using a hand-held refractometer that uses natural light to measure the percent sugars within fruit juices. The 3-way interaction was not significant across cultivars, treatments, and years, but treatment $x$ year was significant $(\mathrm{p}<0.05)$. As shown in figure 6, there were no significant differences between cultivars. Average fruit size and percent soluble solids were tested for correlation in both years. Table 6 lists average percent soluble solids per cultivar by treatment and year.

Figure 5 shows treatment comparisons between years. In both years, the high tunnel treatment produced the lowest percent soluble solids, with less than 9 and 7 percent soluble solids in 2011 and 2012, respectively. In 2011, the high tunnel differed significantly from the low tunnel and control treatments $(\mathrm{p}<0.05)$, while in 2012, the control and high tunnel treatments did not differ. Average sweetness was always lower than nine percent, which is the commercially acceptable U.S. No. 1 grade.

In both years the low tunnel treatment produced significantly sweeter fruit than the high tunnel and control treatments. Sweeter fruit was produced in 2011 (>10\% soluble solids) than 2012 ( $<10 \%$ soluble solids). 
The control treatment produced sweeter fruit in 2011 than 2012. In 2011

average treatment sweetness was greater than nine percent, but in 2012 it was less than eight percent soluble solids.

Correlation tests: Average fruit size and percent soluble solids scores per cultivar were tested for correlation using Pearson correlation coefficients. In 2011, fruit size and percent soluble solids were not correlated for any cultivar. In 2012, 'Earlichamp' was the only cultivar with fruit size correlated with soluble solids level $\left(\mathrm{R}^{2}=.66494\right)$.

\section{Effect of location within the High Tunnel}

Total yields were compared between center and edge plots (Table 7).

Marketable yields were not analyzed since each year an insect/disease issue negatively affected marketable yields, but not total yields. It was hypothesized that environmental conditions may vary with location within the high tunnel, and affect plant response accordingly. Edge plots were located only 0.6 meters from side vents, and were more exposed to moisture moving in from outside the tunnel than the center plots were. Also, center plots would not experience the same ventilation as the edge plots since endwalls were left in place and plants were trellised. A significant 3-way interaction between cultivar $\mathrm{x}$ location $\mathrm{x}$ year was present $(\mathrm{p}<0.05)$, however no 2 -way interactions were significant. Since there were significant changes in yield between years, each year will be reported separately. Due to the significant interactions the results are presented grouped by year and by cultivar (Figure 7).

In 2011, summarizing total yields across edge and center plots revealed very similar results. When summarizing by cultivar, only 'Lil Loupe' and 'Sivan' had 
significant differences in total yields between center and edge plots $(\mathrm{p}<0.05)$. Each yielded more in edge plots over center plots by 80 and 65 percent for 'Lil Loupe' and 'Sivan', respectively. 'Athena', 'Sarah's Choice', and 'Sweet Granite' all yielded more in center plots than edge plots, by approximately 50,10, and 25 percent. 'Tasty Bites' yielded slightly more in edge plots, but by less than ten percent.

In 2012, overall total yields between center and edge plots were similar. There were no significant differences in cultivar center and edge comparisons. 'Earlichamp', 'Lil Loupe', and 'Sivan' all yielded more (by approximately 40-50 percent) in center plots than edge plots. 'Athena' yielded more in edge plots than center, but only by 20 percent, while 'Tasty Bites yielded more in center plots by the same percentage. 'Sarah's Choice' had little variation in total yields between test plots with the center plots yielding only five percent more.

\section{Discussion}

\section{Earliness}

Average first harvest dates for each cultivar and treatment combination and across treatments were analyzed. Planting date and cultivar had the greatest effects on earliness, more than treatment. Overall, the high tunnels had earlier first harvests in both years than the low tunnel and control treatments, though significant differences varied across treatment and years.

In 2011, planting occurred on the same day across all treatments, with first harvests less than 60 days after transplanting. First harvests for most cultivars in all treatments were within two days of each other. Even though the control treatment was statistically different from the high and low tunnel treatments, first harvest days were 
within two to four days of the high tunnel treatment. Seeding for both the high and low tunnel treatments were within one day of each other, while the control was seeded 11 days later (Table 1). Difference in seeding dates between the high and low tunnel treatments from the control may have caused the significant differences. These earliness results are in contrast to a similar tunnel production study conducted in Saskatchewan, Canada. Waterer (2003) harvested muskmelon from high tunnels two to three weeks earlier than low tunnel treatments (covered in perforated plastic) that were planted at the same time (last week of May). Waterer noted two of the three growing seasons as cool so this may have accentuated the difference, as muskmelons thrive in warm and not cool conditions. Jett (2006b) stated that yearly seasonal weather patterns have a greater affect on earliness than the high tunnel environment. In this study, both years had similar weather patterns and were favorable for muskmelon production. Since weather conditions were favorable, this may explain the similarities between the high and low tunnel treatments in 2011. After removal of coverings in mid-June, warm, sunny conditions favored muskmelon growth.

In 2012, treatments were purposely not planted on the same day with the intent to plant each treatment as early as conditions and treatment would allow. As a result of different planting dates, each treatment differed significantly from the others. The protected environment in the high tunnel allowed for flexibility in bed preparation (since rain was not a concern), and earlier planting by almost two weeks over field treatments. The high tunnel treatment was planted nine and twenty-three days earlier than the low tunnel and control treatments, with average first harvests across cultivars beginning seven and seventeen days earlier than the low tunnel and control treatments, 
respectively. The low tunnel and control treatments were planted 14 days apart, with harvests beginning in the low tunnel ten days earlier than the control. Average first harvest across treatments began 63 days after transplant in the high tunnels and 56 days in the low tunnel and control treatments. Earlier plantings in high tunnels may not always coincide with great gains in earlier harvests when compared to other tunnel treatments, especially if spring weather is cloudy. In 2012, average air temperatures in the high tunnel were almost three degrees Celsius cooler than the low tunnel treatment. This is likely an effect of the earlier planting dates.

Generally, covered cultivation allows for an earlier start to the season, which in turn can provide direct-to-market growers a lucrative marketing advantage (Bonanno and Lamont, 1987; Waterer, 1993). Overall, the high and low tunnel treatments did allow for earlier harvests when compared to the control treatments in both years. As summarized in Table 4, average air temperatures under coverings were warmest in the low tunnel treatment, and coolest in the control in 2011, and speculated cooler for 2012 (air temperature recorders failed for the control treatment in 2012). The control covering material was a net (ProtekNet) that allowed excellent air movement, and presumably similar air temperatures to the open field environment, which averaged six degrees Celsius cooler than the low tunnels. Waterer (1993) reported similar results for muskmelon in that warmer air temperatures in plastic tunnels when compared to fabric tunnels accelerated plant development enough to produce differences in earliness.

\section{Harvest Distribution}


Harvest distribution was measured by comparing weekly fruit harvest counts per cultivar by treatment. Peak harvest dates represents the days the majority of fruit was harvested per cultivar; however, statistical analyses were not done on peak harvest. Distribution was greatly affected by the intertaction of treatment, cultivar, and harvest week, and was especially noticeable in the high tunnels (Figures 1 and 2). The high tunnel treatment extended the harvest season when compared to the field treatments; this may be due to some cultivars not favoring the high tunnel environment ('Sivan' and 'Tasty Bites'), or because of genotypic response or sensitivities to the microclimate and/or differing soil properties within the high tunnel, mainly the lower $\mathrm{pH}$. Soil $\mathrm{pH}$ in the high tunnels was below acceptable range (which can be common for New England soils), and this may have had an adverse effect. Peak harvests were somewhat bimodal for the high tunnel treatment in both years, which differed from the bell-shaped distribution of the low and control treatments (Figures 1 and 2). Loy and Wells (1975) reported that rate of fruit ripening for several different hybrid muskmelons differed by production system (rowcovers, plastic mulch only, bare soil and combinations). In this study, once covers were removed from field treatments in June, both treatments experienced the same growing conditions; this may explain the similarities in harvest distribution between the two. The environmental conditions (air circulation and solar radiation) within the high tunnel treatment differed since covers remained.

Yields

Weight (total, marketable, and cull), and total fruit quantity were measured by cultivar across treatments and by treatment alone. The low tunnel treatment provided 
the most consistent and positive results across both years (Figures 8 and 9). Average air temperature during period of cover across all treatments was warmest and most similar in the low tunnels in both years (Table 4). As shown in figures 8 and 9, yields, both quantity and weight, differed dramatically between years for the high tunnel and control treatments. Disease and insect pests negatively affected production each year, with variations in production response. The high tunnel and control treatments showed greater susceptibility to the disease and pest issues than the low tunnel treatment. Possible reasons involve differences in cultivar response to environmental factors, disease and pest issues, and planting dates.

In 2011, gummy stem blight, caused by Didymella bryoniae, was a confounding factor across all treatments and affected each cultivar regardless of production system. The disease had not been a problem previously on the farm, but the causal fungus can be spread in seed. Since the tunnel environment generally reduces disease problems, no preventative fungicides were used. Tunnel production in conjunction with plastic-mulched soil and drip irrigation helps maintain a dry environment which limits the conditions needed for diseases to thrive and spread resulting in less pesticide usage (Jett, 2006b; Wells, 1991). At diagnosis, gummy stem blight was well-established in the high tunnels. The only control option available was pruning and removal of wilted vines since there are no organic fungicides that offer effective control. Disease symptoms were first noticed in the high tunnels, and rate of spread was likely increased by vine pruning. Trellising may also have reduced air movement within the tunnels resulting in greater disease incidence (Blomgren and Frisch, 2007). The disease did not spread as quickly in field treatments possibly 
because vines were not pruned, and less time was spent handling field plants.

However, susceptible cultivars were eventually equally affected in all treatments. Highly susceptible cultivars exhibited symptoms on both stems and leaves, which quickly decreased plant vigor and negatively affected fruit quality. The cultivars most susceptible were 'Sivan' and 'Tasty Bites'; 'Sweet Granite' showed good vine resistance, but fruit ripened prematurely and as a result percent soluble solids were very low (fig. 3). Wolukau et al. (2007) noted that gummy stem blight resistance could differ within genotype due to variations in environmental factors and fungal strains across regions. In this study, (especially for the most susceptible cultivars) it is possible that variation in environmental factors within treatments affected genotypic response to gummy stem blight.

In year two, gummy stem blight did not occur but striped cucumber beetle (Acalymma vittatum) emerged earlier (June 2011 versus May 2012) in 2012 and caused vines to decline later in the season, especially once vines were heavy with fruit. When beetles first emerged, all treatments were protected by cover so bacterial wilt (Erwinia tracheiphila), which is vectored by striped cucumber beetle, was never detected in any of the treatments. Striped cucumber beetle larvae caused the greatest stress. Cline et al. (2008) studied effective rowcover use on diminishing initial and secondary cucumber beetle damage on muskmelon transplants and found that 24 days of cover significantly increased total melon weight, fruit numbers, and vine coverage. Covers were removed to allow for pollination. In both years of this experiment, test plots were covered less than 20 days. Hill (1997) observed that striped cucumber beetles reduced fruit weight and caused fruit to ripen prematurely. Eggs laid in the 
soil at the base of the melon plants hatch to larvae that feed on fine feeder roots and basal stems. Plants displayed symptoms similar to those associated with bacterial wilt; leaves began wilting at vine tip and wilting proceeded back to the canopy. Vine samples were examined and cultured for bacterial wilt and gummy stem blight, but samples were always found to be free of disease-causing pathogens. Highly susceptible cultivars eventually completely wilted. Through regular field observations, 'Tasty Bites' experienced rapid plant decline, with 'Lil Loupe' and 'Sivan' also susceptible to eventual plant decline. While not measured, casual investigations of the soil at the base of wilted 'Tasty Bites' plants revealed a healthy population of striped cucumber beetle larvae.

Poor vine health in both years negatively affected yields and fruit quality, especially for the high tunnel and control treatments. While initial growth within the high tunnels was vigorous for all cultivars each year, the high tunnel environment produced less fruit—especially for 'Sivan' and 'Tasty Bites'—when compared to the low tunnel treatment. Waterer (2003) suggested that muskmelon cultivars bred for a longer growing season — versus the shorter, cooler growing seasons of Canada—may have a higher overall yield potential within high tunnels. Possibly, cultivars bred for cool growing seasons may not produce/adapt well in the warmer environment of the high tunnel thus affecting plant vigor once vines are stressed with fruit load. Compared to the other cultivars in this study, 'Tasty Bites' and 'Sivan' have a longer days-to-harvest ( $\approx 80$ days), but seed company field trials proved positive for cold climates. One shared trait between the two cultivars that is not shared with the others is that 'Sivan' is a charentais-type melon, and 'Tasty Bites' is a cross between 
charentais and ananas. It is not clear if this is an influencing factor in poor high tunnel response.

Greenhouse climatic conditions may alter vegetables' physiological processes and lead to differences in appearance and quality (Gruda, 2005). Both Waterer (2003) and Jett (2006a) stated that fruit grown in high tunnels were larger than field-grown fruit. Wiebe (1973) and Hill (1997) reported that average fruit size did not vary amongst fabric and plastic tunnels. A dominant ranking was not evident in this study with average fruit size across years. In year one, the high tunnel treatment produced the largest fruit on average, with no difference between the field treatments. However in year two, the smallest fruit was produced in the high tunnel treatment with again, no difference in the field. In year two, aphid populations within the high tunnels may have reduced plant vigor enough to compromise fruit size. Vegetable crops infested with aphids may experience reduced plant vigor and production of sugars due to aphid damage to leaves (photosynthesizing organs) (Capinera, 2009; Delahaut, 2001). In this study, melon plants exhibited tip curling, and sooty mold was present in aphid hot spots. Test plots located in the screened high tunnel—-for a pollination experiment summarized in chapter three - experienced the most damage, with test plots failing to produce a marketable crop even with control measures employed (insecticidal soap applications and release of ladybird beetles). The two open high tunnels had aphids as well, but populations were eventually controlled and reduced with a combination of native predators, spraying, and release of ladybird beetles. Field treatments did not have aphid issues. It was difficult to determine the cause for the difference between field treatments and high tunnel aphid populations. Tissue sample tests taken in year 
two did not reveal great differences in percent dry weight in nitrogen between the high tunnel and field treatments so it is unlikely that aphids were attracted to high tunnel plants because of nitrogen levels. The two treatments differed by 0.60 percent, with the high tunnel having the greater nitrogen level of 5.58 percent. This was slightly above the sufficiency range, which had a top range of five percent.

Planting density differences between the high tunnel and field treatments likely did not influence fruit size and yields. In-row spacing for the field was $60 \mathrm{~cm}$ and 45 $\mathrm{cm}$ for the high tunnels. A common practice in high tunnels is to maximize production by efficiently using the limited space (Lamont et al., 2003). Jett (2006b) recommended $60 \mathrm{~cm}$ in-row spacing for high tunnel muskmelon production along with trellising. Waterer (2003) did not trellis the melons and planted at $30 \mathrm{~cm}$ in-row spacing with productive yields and quality fruit. Soluble solids were not affected by planting density in either study, and Waterer (2003) reported no differences from field production. The benefit of increasing planting density would be to achieve greater yields, but average fruit weight may also decrease (Nearson, 2002). In this experiment, it was difficult to determine if increased planting density within the high tunnel had a noticeable impact when compared to field treatments because the confounding impacts of gummy stem blight in year one and aphids in year two.

The control treatment likely produced fewer fruit than the low tunnel treatment because the material used (spun polyester and netting) did not allow the same rapid, vegetative growth as the plastic tunnels. In year one, control plots were covered with spunbonded polyester (Agribon-15), while the low tunnels were covered with a combination of perforated plastic and spunbonded polyester. Average air 
temperatures were greater in the low tunnel treatment by two degrees Celsius over the control, with negligible differences in soil temperatures (Table 4). In year one, low tunnels had to be manually vented on sunny days because within the first week of transplanting, plants began showing signs of heat stress, e.g., stem burn. It is uncertain what caused the stem burn. Both Jett (2006) and Orzolek (1996) stated that heat funnels escaping from black mulch can girdle vegetable stems. In this study, some of the low tunnel transplants were leggy and lying on the black plastic, which may have been burned the stem. The control treatment, which had younger, more upright transplants at time of planting, did not have any stem burn damage.

Differences in seeding/planting dates may have been an influence as well in affecting overall growth response per field treatment. As detailed in Table 4, even though transplanting occurred on the same day in year one, control transplants (26-day old transplants) were eleven days younger than low tunnel transplants (37-day old transplants). Low tunnel test plots had the advantage of being eleven days older, and having a warmer growing environment compared to control test plots.

In year two, temperature recorders within the control treatment failed; however, since the covering was ProtekNet — allows for excellent air movement — it is possible that air temperatures under the netting were similar to open field temperatures. The change in cover combination for the low tunnels (slitted plastic and ProtekNet) in year two was highly effective at eliminating manual venting. This made for a potentially greater temperature difference between the two field treatments. The average temperature difference between the low tunnel treatment and open field was six degrees Celsius. The low tunnel transplants did not show any signs of heat stress, 
and instead thrived under the coverings. In year two, both treatments were planted out with approximately the same-aged transplants, but at different planting dates (Table 4). In both years, after removal of covers, the low tunnel treatment had bigger, more robust vines than the control treatment. This may have given them an advantage in production over the smaller plants in the control treatment when insect pests and disease pressure was present.

\section{Fruit Quality}

Melon plants with larger plant canopies have been shown to produce sweeter fruit as well because of the increased ability to photosynthesize and translocate sugars produced in the leaves to the fruit (Hubbard et al., 1990; Kultur et al., 2001).

Differences in plant size and vigor between the control and low tunnel treatment likely explain some of the variability in yield and soluble solids. Plants in the high tunnel treatment had the greatest vine lengths, but this did not seem to correspond to greater quality.

Melon fruit quality has been shown to be most affected by environmental factors and plant health during final days before harvest. Lingle and Dunlap (1987) demonstrated that the greatest sugar increase in muskmelon occurred ten days before full-slip, and was correlated with increased sucrose synthesis. Similarly, Bianco and Pratt (1977) reported that almost half of the fruit's sugars were translocated during the last week of ripening. Bouwkamp et al. (1978) reported that air temperature, rainfall, and solar radiation were most influential on fruit quality within the last 1-3, five, and six days, respectively, with solar radiation being the most important environmental factor. Similarly, Wells and Nugent (1980) reported that soil moisture had the greatest 
effect on fruit quality right before harvest. On average, melons were sweeter in 2011 than in 2012 (Fig. 5). As recommended by Jett (2006a), each treatment received 2.54 $\mathrm{cm}$ of water each week (one inch of water/week), with weekly fertigation. Regular watering was reduced in all treatments approximately one week before harvest. Since water amounts were not measured, it is difficult to determine if variation in water schedule affected soluble solids and overall quality.

Effect of Location within the High Tunnels

Results for location effect were not consistent across years. Cultivars 'Sivan' and 'Lil Loupe' did not display a location effect in 2012 as they did in 2011. Other cultivars did not show a location effect in either year. The potential for differences in yield and quality is still possible. Wien (2009) noted that without protective screening in high tunnel production, insect pressure may be greater at the edge rows closest to the side walls than center rows. This effect was observed in the high tunnels, but formal data were not collected, and overall edge yield did not differ significantly from center yields. Some edge plots did experience extensive vine damage in 2012 from woodchucks and rabbits. It was hypothesized that differences in soil moisture may have caused yield differences with the two cultivars. In 2012, tensiometers were used to gauge soil moisture. The readings did not reveal differences in soil moisture between center and edge plots, but the accuracy of the instrument was questionable. Adams et al., (2000) reported that greater sunlight exposure for edge plantings versus center plantings increased tomato yields for edge plots. As mentioned earlier, solar radiation is the most important factor in affecting soluble solids level in muskmelon, whether it affects muskmelon yield is still questionable and not supported by this data. 


\section{Conclusion}

Based on these results, low tunnels are the recommended production system for muskmelon in southern New England. In both years, the system consistently produced greater total yields, fruit quantity, and sweetest fruit when compared to the high tunnel and control systems. I speculate that the success is caused by the plant's ability to thrive in the high heat generated by the plastic low tunnels. Since covers are removed at flowering, the low tunnel system also provides excellent air circulation and access to pollinators and natural predators for insect pests. The high and low tunnel treatments did allow for earlier harvests when compared to the control treatment. As reported by Jett (2006a) and Waterer (2003), the high tunnel system has advantage greater potential than either field treatment to produce early yields because of enhanced soil-heating capabilities and a dry environment that allows for flexibility in bed preparation. Though percent soluble solids were highest in fruit produced in the low tunnel system, it was difficult to determine why. Cultivar had the strongest effect on percent soluble solids.

The results of this study suggest muskmelon productivity is influenced not only by genotypic response, but possibly by microclimate effects as well. Some of the cultivar performances in this study were not affected by treatment, but with others a treatment effect was present. The cultivar 'Sarah's Choice' had the most consistent quality regardless of treatment. 'Lil Loupe' also performed satisfactorily within all treatments even with disease and insect pressure. 'Sivan' is not recommended for high tunnel production because of its poor performance during both years of the study.

Further study is warranted to gain a better understanding of microclimate 
impact on physiological processes of muskmelon grown in high tunnels versus low tunnel and open field production. It is possible water needs were not met in the high tunnel considering the environment allowed for extensive vine growth, especially under the warm and sunny conditions during the 2011 and 2012 growing seasons. Evaluating different water regimes within high tunnels during both cool and warm growing seasons would be useful for growers in southern New England. Additionally, measuring solar radiation and photosynthetic rates between systems may offer greater power to measure treatment effects.

Exploring these differences may further elucidate some of the quality differences observed within cultivar across the three tunnel treatments tested in this study. As suggested by Waterer (2003), testing cultivars bred for long-season production within high tunnels may result in improved quality and yield when compared to short-season cultivars. None of the cultivars in this study were bred for long-season production. Growers would benefit from continued field trials of suitable regional cultivars tested in multiple production systems. 


\section{References Cited}

Adams, S.R., V.M. Valdés, P.J.C Hamer, and B.J. Bailey. 2000. Spatial variation and comparison of yields of tomatoes in small experimental compartments with those in large commercial units. Acta Horticulturae. 534:93-100.

Agricultural Marketing Services, 2008. U.S. Department of Agriculture. United States standards for grades of cantaloupes. 5 May 2012. < ww.ams.usda.gov/AMSv1.0/ getfile?dDocName=STELPRDC5050255>

Bianco, V.V. and H.K. Pratt. 1977. Compositional changes in muskmelons during development and in response to ethylene treatment. J. Amer. Soc. Hort. Sci. 102:127133.

Blomgren, T. and T. Frisch. 2007. High tunnels: using low cost technology to increase yields, improve quality, and extend the season. Cornell Coop. Ext. 3 Jan 2012. <http://www.uvm.edu/sustainableagriculture/hightunnels.html> Bonanno, A.R., and W.J. Lamont. 1987. Effect of polyethylene mulches, irrigation method, and row covers on soil and air-temperature and yield of muskmelon. 112:735738.

Bouwkamp, J.C., F.F. Angell, and F.D. Schales. 1978. Effects of weather on soluble solids of muskmelon. Scientia Hortic. 8:265-271.

Capinera, J.L. 2009. Featured creatures: Melon aphid or cotton aphid. Unv. of Florida. 23 Mar 2013. <http://entnemdept.ufl.edu/ Creatures/veg/aphid /melon_aphid.htm> 
Carey, E. E., J. Lewis, W. J. Lamont Jr., T.T. Nennich, M. D. Orzolek, and K. A.

Williams. 2009. Horticultural crop production in high tunnels in the United States: A snapshot. HortTechnology. 19:37-43.

Cline, G.R., J.D. Sedlacek, S.L. Hillman, S.K. Parker, and A. F. Silvernail. 2008. Organic management of cucumber beetles in watermelon and muskmelon production. HortTechnology. 18:436-444.

Default, R.J., A. Korkmaz, B.K. Ward, and R.L. Hassell. 2006. Planting date and cultivar affect melon quality and productivity. HortScience. 41:1559-1564.

Delahaut, K.A. 2001. Garden facts: Vegetable aphids. Unv. of Wisconsin Ext. 23 Mar 2013. < http://richland.uwex.edu/files/2012/07/A3757-E.pdf>

Gruda, N. 2005. Impact of environmental factors on product quality of greenhouse vegetables for fresh consumption. Critical Rev. Plant Sci. 24:227-247.

Hemphil, D. 1985. Muskmelon response to floating row covers. 23 Dec $2012<$ http://horticulture.oregonstate.edu/content/muskmelon-response-floating-row-covers1984>

Hendrickson, J.R., J.D. Hanson, D.L. Tanaka, and G. Sassenrath. 2008. Principles of integrated agricultural systems: Introduction to processes and definitions. Renable Agr. Food Sys. 23:265-271.

Hill, D.E. 1997. Effects of multiple cropping and row covers on production of specialty melons. CT Ag. Exp. Station. Ext. Ser. Bul. 745. 21 Dec 2012 <http://ia700603.us.archive.org/10/items/effectsofmultipl00hill/effectsofmultipl00hill. pdf>

Howell, J. C., and R. V. Hazzard, eds. 2010-2011. New England Vegetable 
Management Guide. www.nevegetable.org

Hubbard, J.A. 2011. An inexpensive alternative solar radiation shield for ambient air temperature micro-sensors. J. Nat. Environ. Sci. 2:9-14.

Ibarra, L., J. Flores, and J.C. Díaz-Pérez. 2001. Growth and yield of muskmelon in response to plastic mulch and row covers. Scientia Hort. 87:139-145.

James, Rosalind R. and Theresa L. Pitts-Singer, eds. 2008. Bee pollination in agricultural ecosystems. New York: Oxford Univ. Press

Jett, L. W. 2006a. High tunnel melon and watermelon production. Unv. Missouri Coop. Ext. Ser. Bul. M173. 9 Mar $2012<$ http://extension.missouri.edu/p/ M173>

Jett, L.W. 2006b. Galia muskmelons: A potentially profitable early-season crop for high tunnels in the Central Great Plains. Unv. Missouri Coop. Ext. Ser. 2 Jan $2013<$ http://www.hightunnels.org/PDF/JETT\%20Production\%20Melons.pdf>

Knewtson, S. J. B., E. E. Carey, and M. B. Kirkham. 2010. Management practices of growers using high tunnels in the central Great Plains of the United States.

HortTechnology. 20:639-645.

Kultur, F., H.C. Harrison, and J.E. Staub. 2001. Spacing and genotype effect fruit sugar concentration, yield, and fruit size of muskmelon. HortScience. 36:274-278. Lamont, W. J., M. R. Mc Gann, M. D. Orzolek, N. Mbugua, B. Dye, and D. Reese. 2002. Design and construction of the Penn State high tunnel. HortTech. 19: 37-43. Lamont, W.J., M.D. Orzolek, E.J. Holcomb, K.Demchak, E. Burkhart, L. White, and B. Dye. 2003. Production system for horticultural crops grown in the Penn State high tunnel. 13:358-362. 
Lamont Jr., W.J. 2005. Plastics: Modifying the microclimate for the production of vegetable crops. HortTechnology. 15:477-481.

Lingle, S.E., and J.R. Dunlap.1987. Sucrose metabolism in netted muskmelon fruit during development. Plant Phys. 84:386-389.

Loy, J. B., and O. S. Wells. 1975. Response of hybrid muskmelons to polyethylene row covers and black polyethylene mulch. Scientia Hort. 3:223-230.

MacGillivray, J.H. 1947. Soluble solids content of different regions of watermelons. Plant Physiol. 22:637-640.

McGregor, S. E., M. D. Levin, and R. E. Foster. 1965. Honey bee visitors and fruit set of cantaloups. J. Econ. Ent. 58:968-970.

Motsenbocker, C.E., and A.R. Bonanno. 1989. Row cover effects on air and soil temperatures and yield of muckmelon. HortScience. 24:601-603.

National Agriculture Statistics Service (NASS). 2009. U.S. Census of Agriculture. Small farms fact sheet. USDA: Washington. 3 May 2012 <http://www.agcensus.usda.gov/Publications/2007/Online_Highlights/Fact_Sheets/Far m_Numbers/small_farm.pdf>

Nearson, H. Relationship between plant density and fruit and seed production in muskmelon. J. Amer. Soc. Hort. Sci. 127:855-859.

Orzolek, M.D. 1996. Stand establishment in plasticulture systems. HortTechnology. 6:181- 185.

Sassenrath, G.F., J.M. Halloran, D. Archer, R.L Raper, J. Hendrickson, P. Vadas, and J. Hanson. Drivers impacting the adoption of sustainable agricultural management systems of the northeast and southeast Unites States. J. Sust. Agr. 34:680-702. 
Waterer, D.R. 1993. Influence of planting date and row covers on yield and economic value of muskmelons. Can. J. Plant Sci. 73:281-288.

Waterer, D.R. 2003. Yields and economics of high tunnels for production of warmseason Vegetable crops. HortTechnology. 13:339-343.

Wells, O.S. 1991. High tunnels shelter early crops. Amer. Veg. Grower. 39:44, 46-47.

Wells, O.S. and J.B. Loy. 1993. Production and marketing reports: Rowcovers and high tunnels enhance crop production in the northeastern United States.

HortTechnology. 3:92-95.

Wells, J.A. and P.E. Nugent. 1980. Effect of high soil moisture on quality of muskmelon. HortScience. 15:258-259.

Wiebe, J. 1973. Tunnel covers and mulches for muskmelon production. Can. J. Plant Sci.53: $157-160$.

Wien, H.C. 2009. Microenvironmental variations within the high tunnel. HortScience. 44:235-238.

Wolukau, J.N., X. Zhou, Y. Ling, Y. Zhang, and J. Chen. 2007. Resistance to gummy stem blight in melon (Cucumis melo L.) germplasm and inheritance of resistance from plant introductions 157076, 420145, and 323498. HortScience. 42:215-221. 
Table 1. Seeding and planting dates by treatment and year.

\begin{tabular}{|c|c|c|c|c|c|c|}
\hline \multicolumn{7}{|c|}{ Production system } \\
\hline & \multicolumn{2}{|c|}{ High } & \multicolumn{2}{|c|}{ Low } & \multicolumn{2}{|c|}{ Control } \\
\hline & seedin & lanting & see & /planting & seedir & lanting \\
\hline $2011^{z}$ & 26-Apr & 31-May & 25-Apr & 31-May & 6-May & 31-Мау \\
\hline 2012 & 18-Apr & 16-May & 2-May & 25/26-May & 14-May & 8/9-June \\
\hline
\end{tabular}


Table 2. First harvest dates ${ }^{\mathrm{z}}$ are listed by cultivar and treatment.

\begin{tabular}{ccccccc}
\hline & \multicolumn{2}{c}{ Production System } \\
\hline Cultivar & High & \multicolumn{2}{c}{ Low } & \multicolumn{2}{c}{ Control } \\
\hline Athena & 30-Jul & 15-Jul & 31-Jul & 26-Jul & 1-Aug & 3-Aug \\
Lil Loupe & 28-Jul & 13-Jul & 29-Jul & 21-Jul & 31-Jul & 3-Aug \\
Sivan & 30-Jul & 14-Jul & 28-Jul & 19-Jul & 29-Jul & 28-Jul \\
Sarah's Choice & 26-Jul & 13-Jul & 27-Jul & 18-Jul & 28-Jul & 29-Jul \\
Tasty Bites & 28-Jul & 14-Jul & 29-Jul & 20-Jul & 31-Jul & 2-Aug \\
Sweet Granite & 21-Jul & -- & 25-Jul & -- & 25-Jul & -- \\
Earlichamp & -- & 12-Jul & -- & 18-Jul & -- & 29-Jul \\
\hline
\end{tabular}

${ }^{\mathrm{z}}$ First harvest dates are an average of the first days of harvest per cultivar plot and treatment. 
Table 3. Peak harvest represents the days during which the majority of fruit was harvested.

\begin{tabular}{|c|c|c|c|c|c|c|}
\hline \multicolumn{7}{|c|}{ Production System } \\
\hline \multirow[b]{2}{*}{ Cultivar } & \multicolumn{2}{|c|}{ High } & \multicolumn{2}{|c|}{ Low } & \multicolumn{2}{|c|}{ Control } \\
\hline & 2011 & 2012 & 2011 & 2012 & 2011 & 2012 \\
\hline Athena & Aug 1-5 & Jul 16-18 & Aug 1-3 & Jul 30-Aug 3 & Aug 1-3 & Aug 3-6 \\
\hline Lil Loupe & Aug 1-5 & Jul 16-20 & Aug 1-5 & Jul 30-Aug 3 & Aug 1-5 & Aug 1-6 \\
\hline $\operatorname{Sivan}^{\mathrm{Z}}$ & Aug 1-5 & fail & Aug 1-5 & Jul 23-27 & Aug 3-5 & Jul 25-Aug 1 \\
\hline Sarah's Choice ${ }^{\mathrm{y}}$ & Jul 27-Aug 1 & evenly dist. & Aug 1-5 & Jul 25-30 & Aug 1-5 & Jul 30-Aug 1 \\
\hline Tasty Bites & Jul 29-Aug 3 & Jul 18-23 & Aug 1-5 & Jul 20-25 & Aug 1-5 & Aug 3-6 \\
\hline Sweet Granite & Jul 27-Aug 1 & -- & Jul 27-Aug 1 & -- & Jul 27-Aug 1 & -- \\
\hline Earlichamp & -- & Jul 9-18 & -- & Jul 20-23 & -- & Jul 30-Aug 3 \\
\hline
\end{tabular}

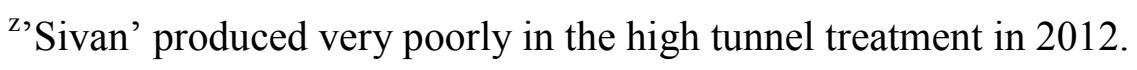

'Sarah's Choice' plots in the high tunnels in 2012 did not produce a peak harvest. Instead, fruit was evenly distributed. 
Table 4. Rowcover microclimate effects on mean air and soil temperatures. Minimum and maximum temperatures listed represent the absolute lowest and highest temperatures for the climate data collection period. Data are missing for open field 2011 soil temperatures and 2012 control air temperatures due to data logger malfunction.

\begin{tabular}{|c|c|c|c|c|c|c|c|c|c|c|c|c|}
\hline & \multicolumn{6}{|c|}{$2011^{z}$} & \multicolumn{6}{|c|}{$2012^{y}$} \\
\hline & \multicolumn{3}{|c|}{ Air temp. $\left({ }^{\circ} \mathrm{C}\right)$} & \multicolumn{3}{|c|}{ Soil temp. $\left({ }^{\circ} \mathrm{C}\right)$} & \multicolumn{3}{|c|}{ Air temp. $\left({ }^{\circ} \mathrm{C}\right)$} & \multicolumn{3}{|c|}{ Soil temp. ${ }^{\mathrm{u}}\left({ }^{\circ} \mathrm{C}\right)$} \\
\hline & $20 \mathrm{~cm}$ & $\min$ & $\max$ & $10 \mathrm{~cm}$ & $\min$ & $\max$ & $20 \mathrm{~cm}$ & $\min$ & $\max$ & $10 \mathrm{~cm}$ & $\min$ & $\max$ \\
\hline High & 23.11 & 7.5 & 39.8 & 24.05 & 21.1 & 28.5 & 21.4 & 6.8 & 45.2 & 21.6 & 15.9 & 28.8 \\
\hline Low $^{x}$ & 24.62 & 8 & 53 & 22.85 & 18.6 & 27.1 & 24.1 & 8.6 & 53.1 & 24.4 & 16.8 & 34.5 \\
\hline Control $^{\mathrm{w}}$ & 22.89 & 6.3 & 52 & 22.51 & 17.8 & 29.6 & -- & -- & -- & 25.3 & 18.5 & 38.5 \\
\hline Open field ${ }^{\mathrm{v}}$ & 20.02 & 5 & 41 & -- & -- & -- & 18.1 & 6 & 33 & 18.6 & 12.5 & 25.5 \\
\hline
\end{tabular}

${ }^{\mathrm{z}}$ Row cover dates for all treatments listed are from June 4 to June 19.

${ }^{\mathrm{y}}$ Temperature dates for high tunnel treatment are from May 12 to June 28. Low tunnel treatment and open field are May 28 to June 12, and control are June 8 to June 27, which represents period of cover.

${ }^{x}$ Perforated plastic with spunbonded polyester (Agribon-15) used in 2011, and slitted plastic with ProtekNet used in 2012.

${ }^{\mathrm{w}}$ Spunbonded polyester (Agribon-15) used in 2011, and ProtekNet used in 2012.

${ }^{v}$ Open field soil temperatures were taken from soil not covered in black plastic mulch.

un 2012, the data loggers used (iButtons) were better insulated from weather since in 2011 some were lost to water damage. This may have affected the temperature. 
Table 5. Average fruit size per cultivar by treatment. Weights per cultivar represent average fruit weights from six plots containing five plants each. Commercial average was obtained from seed source.

\begin{tabular}{cccccccc}
\hline & \multicolumn{3}{c}{2011} & & & \multicolumn{2}{c}{2012} \\
\hline Cultivar & High & Low & Control & $\begin{array}{c}\text { commercial } \\
\text { average }\end{array}$ & High & Low & Control \\
\hline Athena & $1.85 \mathrm{~kg}$ & $1.54 \mathrm{~kg}$ & $1.57 \mathrm{~kg}$ & $2.3-2.7 \mathrm{~kg}$ & $0.98 \mathrm{~kg}$ & $1.65 \mathrm{~kg}$ & 1.63 \\
Lil Loupe & 1.12 & 0.82 & 0.83 & 0.91 & 0.56 & 0.77 & 0.87 \\
Sivan & 0.89 & 0.66 & 0.76 & $.45-.68$ & 0.89 & 0.66 & 0.81 \\
Sarah's Choice & 1.48 & 1.37 & 1.55 & 1.36 & 0.93 & 1.35 & 1.24 \\
Tasty Bites & 0.73 & 0.73 & 0.57 & $.68-1.1$ & 0.31 & 0.50 & 0.47 \\
Sweet Granite & 0.97 & 0.79 & 0.88 & 1.36 & -- & -- & - \\
Earlichamp & -- & -- & -- & $2.0-2.9$ & 1.30 & 1.30 & 1.10 \\
\hline
\end{tabular}


Table 6. Average percent soluble solids across cultivars and treatments per growing season. 'Sweet Granite' and 'Earlichamp' were grown in one growing season only.

\begin{tabular}{lcccccc}
\hline & \multicolumn{2}{c}{ Production System } \\
\hline \multicolumn{2}{c}{ High } & \multicolumn{2}{c}{ Low } & \multicolumn{2}{c}{ Control } \\
\hline Cultivar & 2011 & 2012 & 2011 & 2012 & 2011 & 2012 \\
\hline Athena & $8.83 \%$ & 8.55 & $10.20 \%$ & 9.33 & $10.86 \%$ & 7.35 \\
Lil Loupe & 8.55 & 7.86 & 10.42 & 9.66 & 9.13 & 6.66 \\
Sivan & 8.00 & 7.23 & 11.17 & 8.84 & 9.95 & 6.23 \\
Sarah's & & & & & & \\
Choice & 9.21 & 8.89 & 11.24 & 11.87 & 9.95 & 9.03 \\
Tasty Bites & 9.51 & 7.64 & 10.32 & 8.42 & 9.59 & 7.90 \\
Sweet & & & & & & \\
Granite & 6.78 & -- & 7.83 & -- & 6.25 & -- \\
Earlichamp & -- & 8.61 & -- & 9.26 & -- & 7.34 \\
\hline
\end{tabular}


Table 7. Total weight per cultivar in center and edge plots in the high tunnel treatment.

\begin{tabular}{|l|c|c|c|c|}
\hline & \multicolumn{2}{|c|}{2011} & \multicolumn{2}{c|}{2012} \\
\hline Cultivar & Edge & Center & Edge & Center \\
\hline Athena & $13.65 \mathrm{~kg}$ & $21.08 \mathrm{~kg}$ & $9.14 \mathrm{~kg}$ & $7.52 \mathrm{~kg}$ \\
\hline Lil Loupe & 19.27 & 10.7 & 3.37 & 4.87 \\
\hline Sarah's Choice & 15.97 & 17.3 & 9.8 & 9.26 \\
\hline Sivan & 9.58 & 5.82 & 1.84 & 2.65 \\
\hline Tasty Bites & 8.54 & 7.91 & 2.34 & 2.84 \\
\hline Total & 53.36 & 41.73 & 17.35 & 19.62 \\
\hline
\end{tabular}



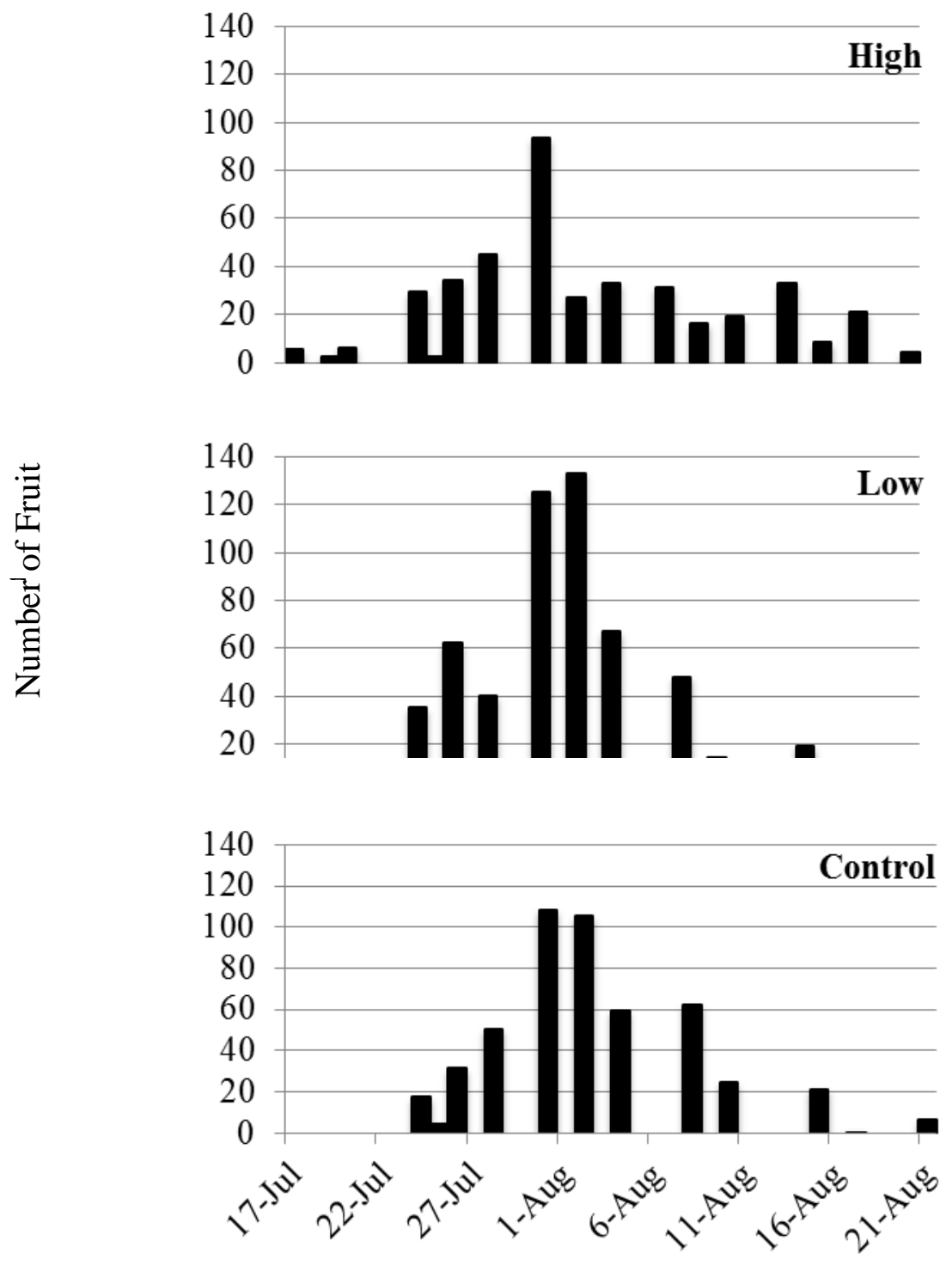

Figure 1. Total fruit harvest distribution per production system for 2011 season. All treatments were planted on May $31^{\text {st }}$. 

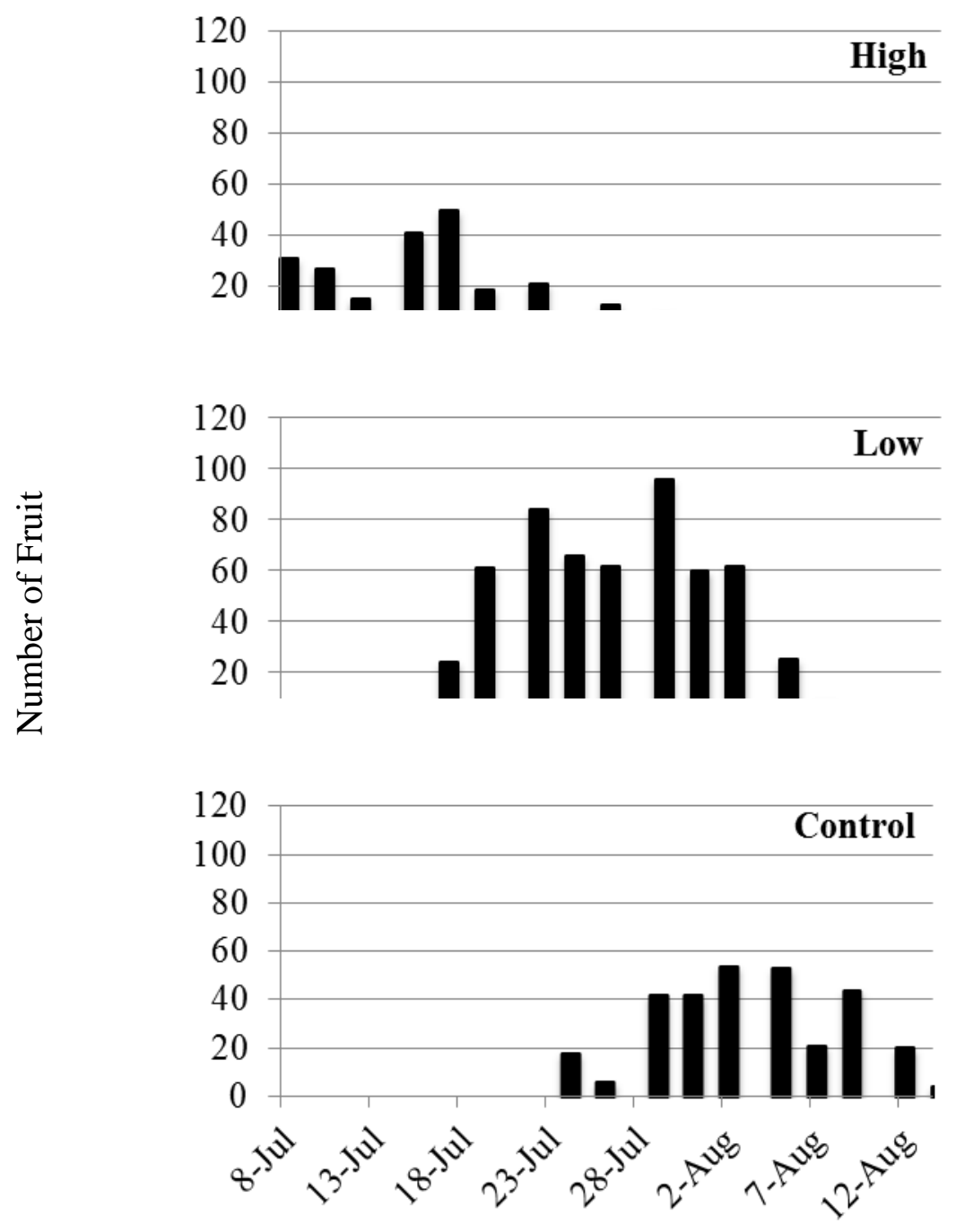

Figure 2. Total fruit harvested per production system for 2012 season. The high, low and control treatments were planted on May $16^{\text {th }}$, May $25 / 26^{\text {th }}$, and June $8 / 9$ respectively. 
2011

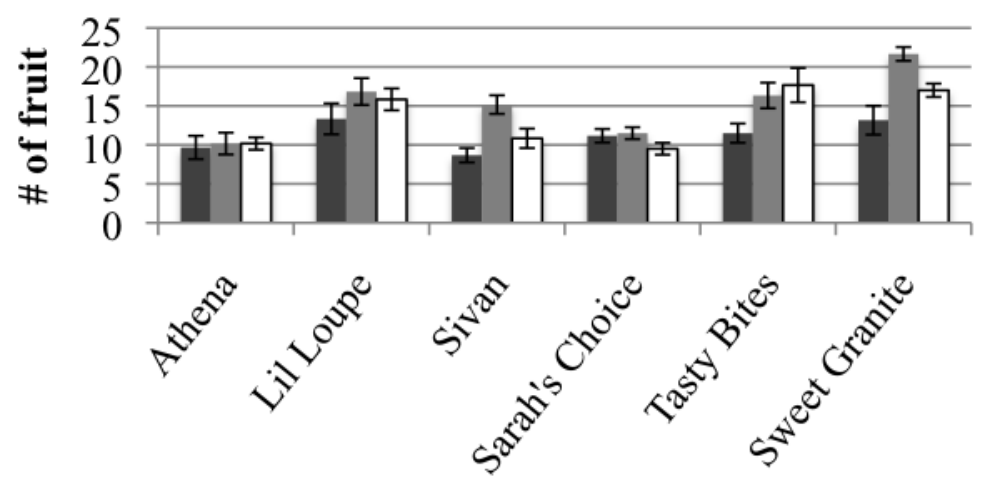

2012
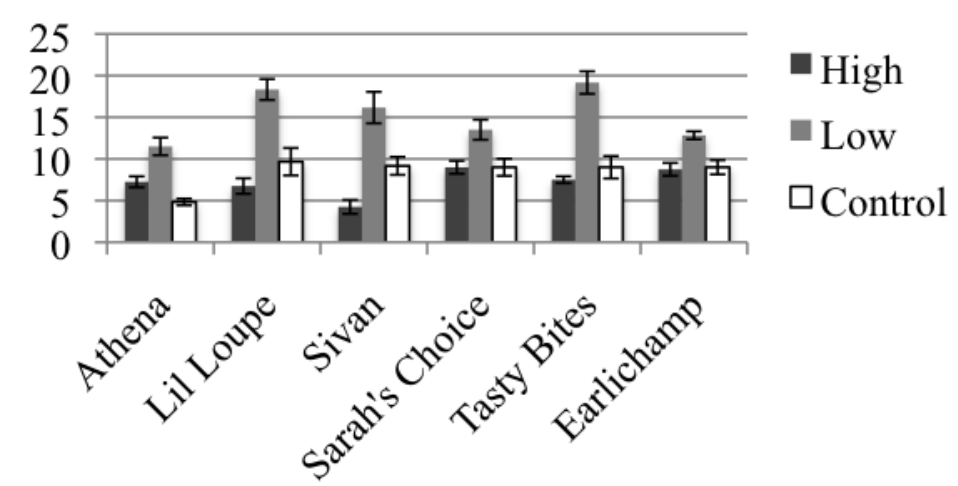

Figure 3. Average total fruit production per variety within treatment. Yields represent averages across six plots, with five plants per plot. Bars represent \pm SE. 


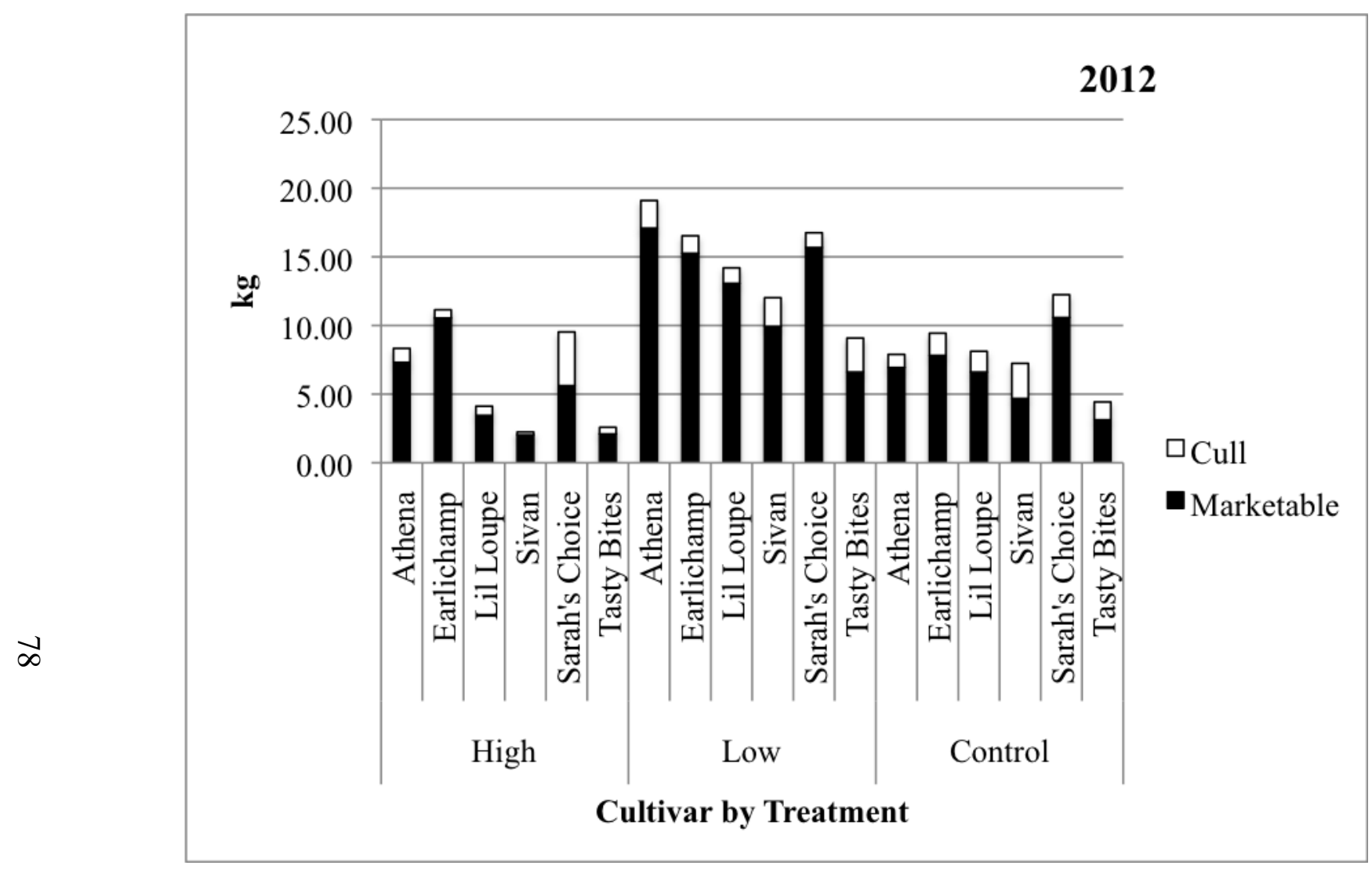

Figure 4. Marketable and cull yields per cultivar grouped by treatment for the 2012 growing season. Yields per cultivar represent average weight across six test plots containing five plants each. 


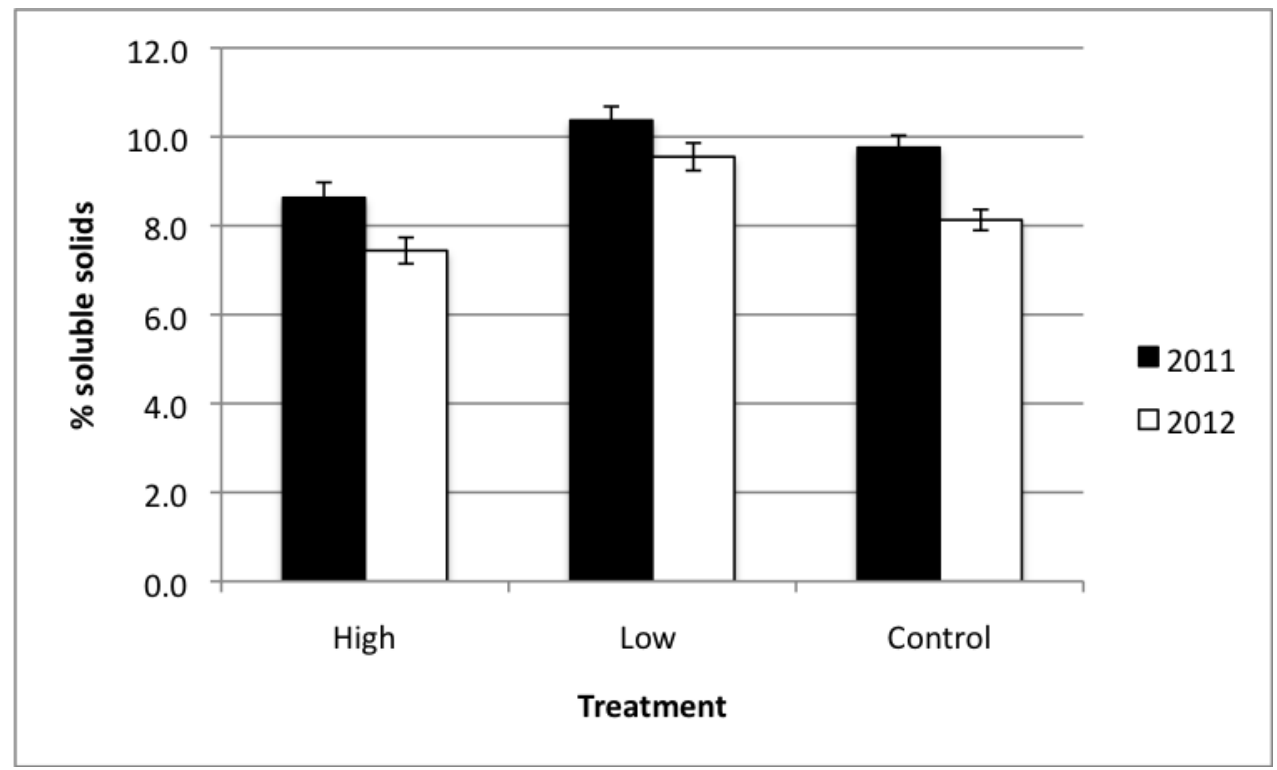

Figure 5. Average percent soluble solids across all cultivars per treatment and year.

Treatment values represent average sweetness across 36 test plots and approximately 100 muskmelons. Number of melon samples differed between cultivars and years.

Bars represent \pm SE. 

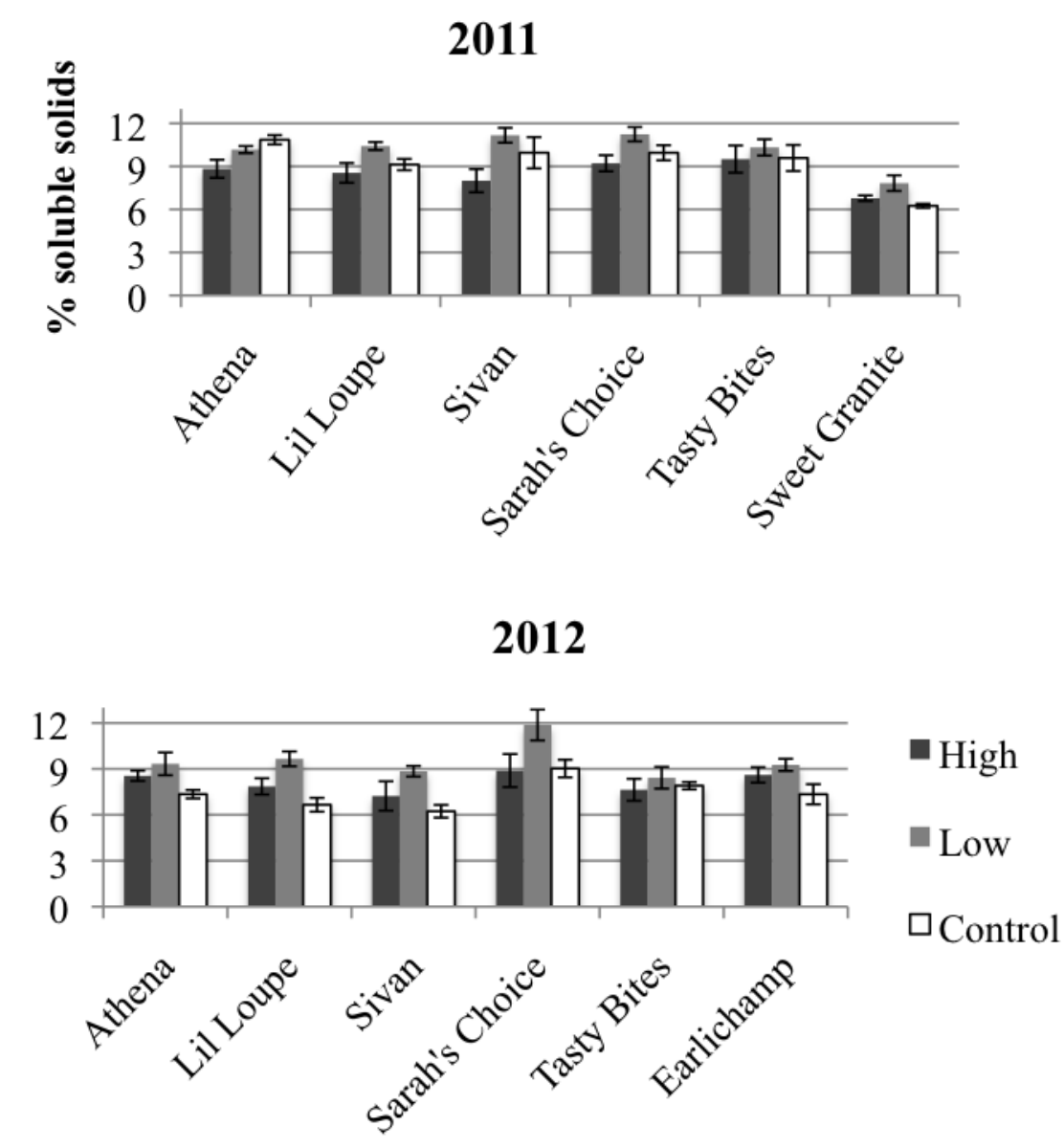

Figure 6. Average percent soluble solids per cultivar and production system.

Bars represent \pm SE. 


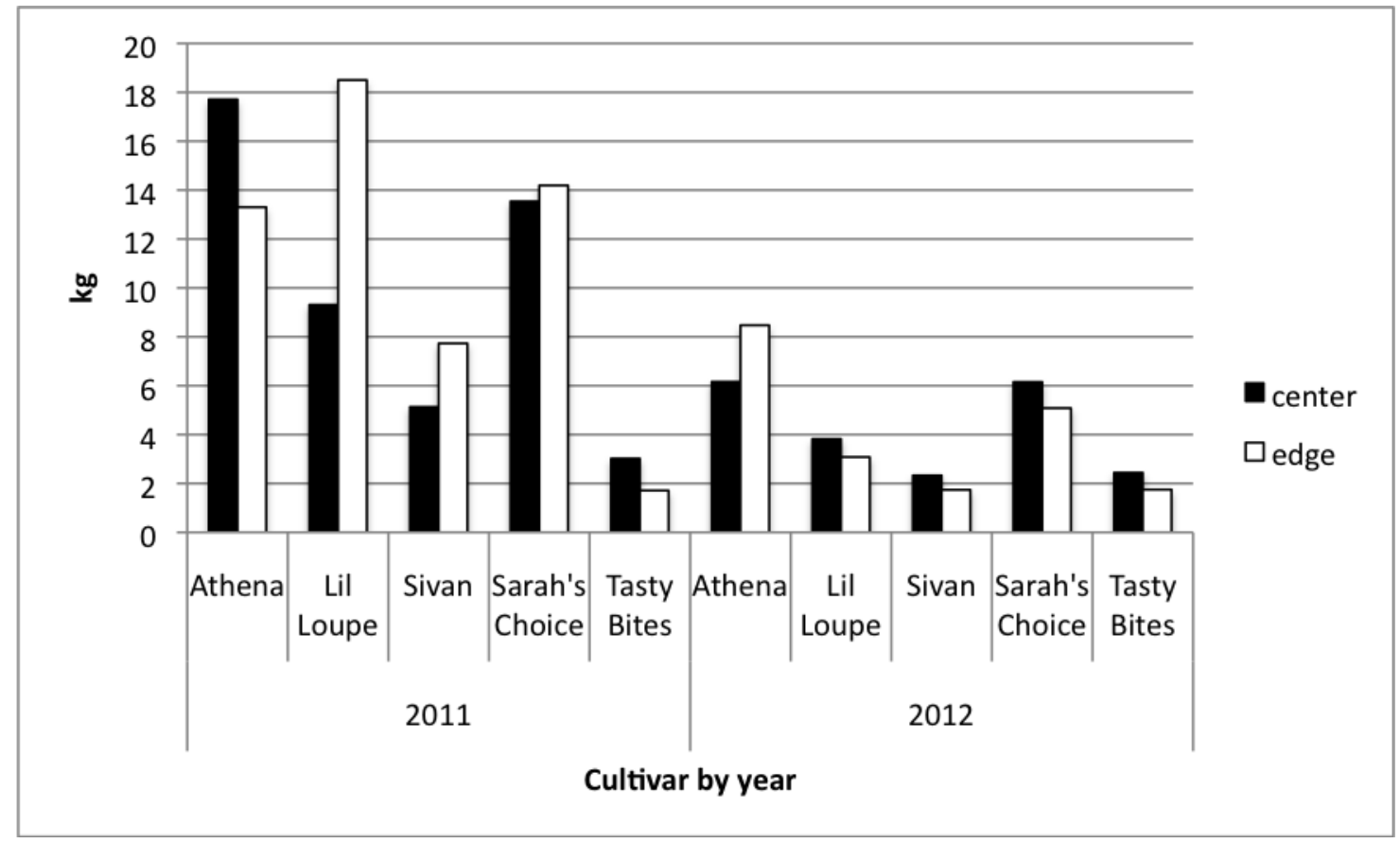

Figure 7. High tunnel location effect on marketable yields for center and edge test plots grouped by year. Values represent average marketable yields across three test plots per location with five plants per plot. 


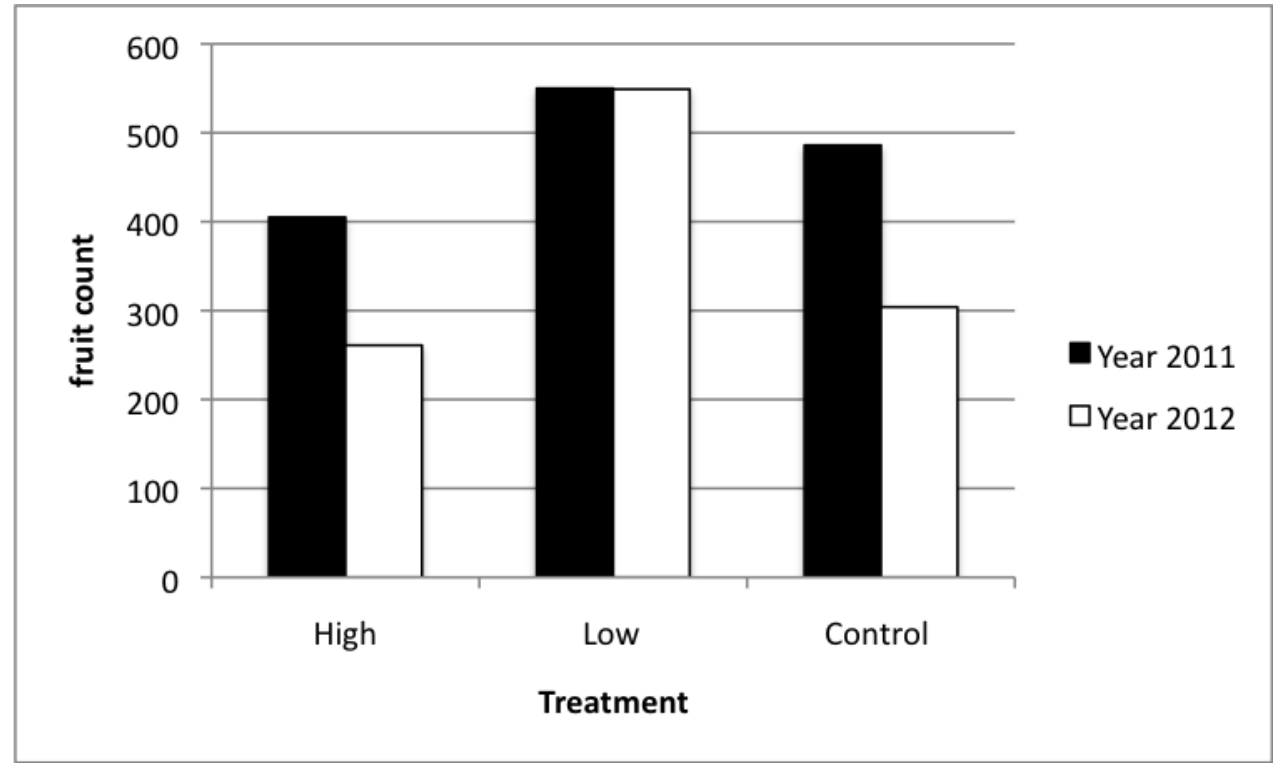

Figure 8. Total fruit counts per treatment and year. Each treatment was planted with 180 plants per year. 


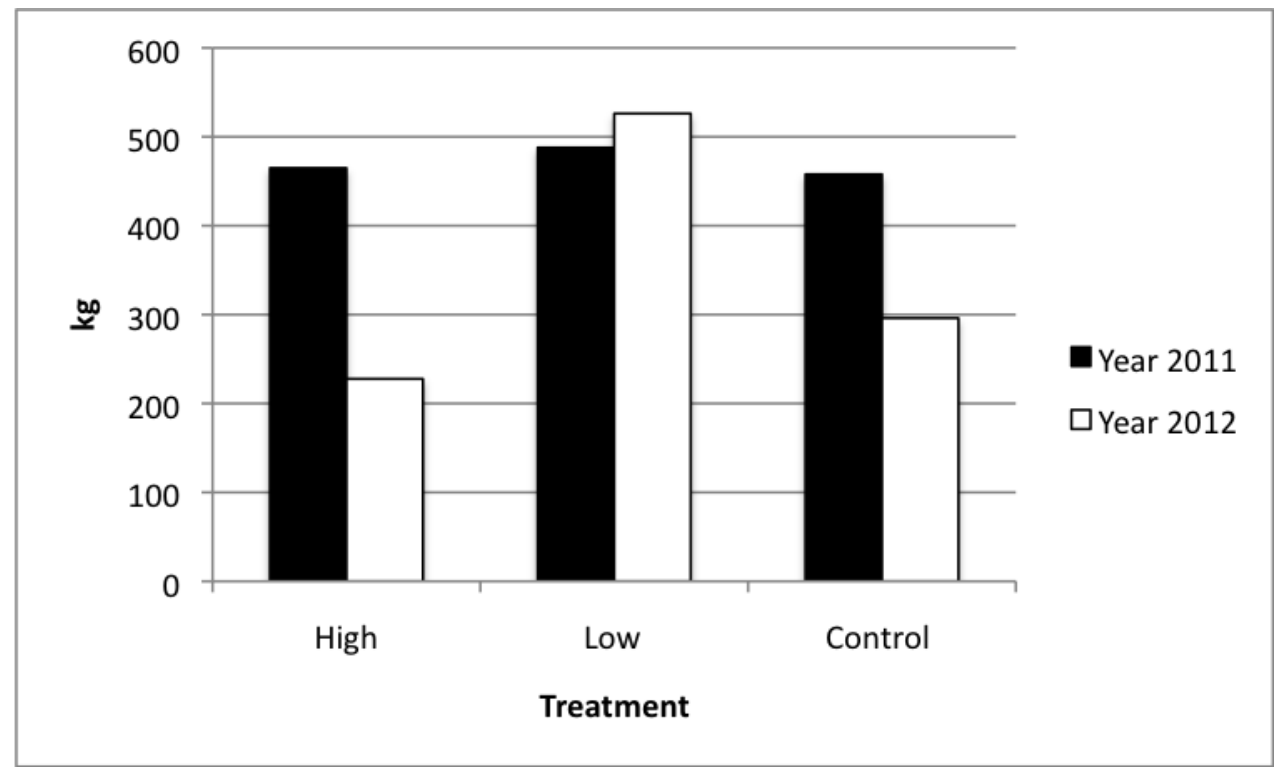

Figure 9. Total weight per treatment is compared across years. 


\section{Chapter 3}

Chapter 3 has been formatted for submission to HortScience.

\section{An Investigation of Pollination Systems in Gothic-styled High Tunnels in Southern New}

\section{England.}

Mina Vescera

Masters Candidate, Department of Plant Sciences and Entomology, University of Rhode Island, Kingston, RI 02881. Email: mina.vescera@gmail.com

Rebecca Nelson Brown²

Associate Professor, Department of Plant Sciences and Entomology, University of Rhode Island, Kingston, RI, 02881. Email: Brownreb@uri.edu

\footnotetext{
${ }^{2}$ Corresponding author and for reprints email Rebecca N. Brown: Brownreb@uri.edu
} 


\section{Introduction:}

Over the last ten years, high tunnel usage has been on the rise in southern New England because of increased demand for locally-grown fresh produce (Blomgren and Frisch, 2007). Commonly used high tunnels in this region are simple, single-span tunnels (Quonset style) covered in polyethylene that may or may not have side ventilation (Giacomelli 2009). While high tunnels can offer significant benefits for season extension and disease prevention, the tunnels pose mortality and navigation problems for honey bees. Lack of ventilation can restrict access (Jett, 2006b) or entrap bees, and the plastic may interfere with the bees' navigation mechanism (James and Pitts-Singer 2008). This may limit the variety of crops growers can produce in high tunnels since several crops depend on pollination for fruit production. The purpose of this experiment was to investigate Gothic-styled high tunnels equipped with side vents and a ridge vent and determine if the style is compatible with European honey bee (Apis mellifera) and eastern bumble bee (Bombus impatiens) pollinator effectiveness. Effectiveness was evaluated using muskmelon, which is dependent on bee pollination for a marketable crop.

The cost to purchase commercially-reared bumble bees or rent a honey bee hive varies depending on coverage area. Even if growers reared their own honey bees and sold the honey produced, labor is still a factor. Native pollination services are a valuable service to a grower since no fee or labor is involved.

When comparing both honey and bumble bee effectiveness in polyethylene tunnels, bumble bees performed better under low ultraviolet (UV) transmission; 
however, bees, including honey bees, are capable of adjusting to their environment (James and Pitts-Singer, 2008). Successful muskmelon production has been reported in glass houses and was attributed to ventilation providing honey bee access to the crop (Dag and Eisikowitch, 1999). The authors also reported that the bees did not show signs of disorientation. Use of good greenhouse glass allows for 80 percent UV transmission, which is enough for normal foraging behavior. High tunnels are covered in polyethylene plastic, which have a UV stabilizer incorporated into the plastic.

Polyethylene UV-blocking plastics reportedly reduce transmission of ultraviolet light by 30 percent or more (James and Pitts-Singer, 2008). Decreased UV transmission into the high tunnel may interfere with the bee's ability to pollinate flowers successfully (Peitsch et al., 1992). Yields may be compromised as a result. Researchers and growers have placed hives, both honey and bumble bee, in high tunnels as a means to improve pollination (Jett 2006b, Blomgren and Frisch, 2006).

This study investigated: (i) if the gothic high tunnel design incorporating roof vents was conducive to successful pollination of muskmelon (ii) whether hive placement inside the high tunnel allowed for earlier foraging than hives placed outside the tunnel, and (iii), if pollination system affected fruit yield and quality.

\section{Methods}

Research Site: This experiment was conducted during the 2011 and 2012 growing seasons at the University of Rhode Island Greene H. Gardener Agricultural Experiment Station (Kingston, RI) 
High Tunnels: Three Gothic-style tunnels each measuring 22 x 6 meters with $1.2 \mathrm{~m}$ sidewalls and a height of $4 \mathrm{~m}$ at the peak were arranged in an east-west orientation with 3 meters between tunnels. Tunnels were covered with a single layer of 6-mil (0.153-mm), 4-year Tufflite IV greenhouse polyethylene (Berry Plastics Corp., Evansville, IN). Planting rows, measuring $11.43 \mathrm{~m}$, were oriented east to west with two rows occupying the interior and two rows occupying the outer edge rows for a total of four rows per tunnel. Test plots (five per row with two buffer plots) were centered in the high tunnels and measured $0.8 \times 2.3$ meters with 0.46 meter in-row spacing. A simple trellis consisting of sisal twine, rebar, and orchard wire supported the vines and fruit

Ventilation was provided by 1.2-meter roll-up vents on each side and by an automated 0.5-meter roll-up ridge vent that runs the length of the tunnel (Nolt's Produce Supplies, Leola, PA). The automated ridge vent was set to open at 18 degrees Celsius. Side vents were manually vented until nighttime temperatures were above 15 degrees Celsius; thereafter, vents and the doorway remained open, however endwalls remained in place. The high tunnel with the bumble bee hive was screened to keep bees from foraging elsewhere and to exclude honeybees.

Pollination systems: Three pollination systems were tested: European honey bee (Apis mellifera) hive within an open tunnel; eastern bumble bee (Bombus impatiens) hive within a screened tunnel; and an open tunnel without a hive but accessible by wild bees and honey bees from nearby hives. A local beekeeper provided a small nucleus hive for the high tunnel, and a commercially-sized hive for the field. A class C sized bumble bee colony (adequate for up to 454 square meters) was purchased 
from Koppert Biological Systems (Howell, MI, USA). In 2011, the field honey bee hive was within 6 to 30 meters of the high tunnels. In 2012, the field hive was placed approximately 600 meters away. Both honey and bumble bee hives were put in place as melon flowers began blooming. Motion-detective cameras (Bushnell Trophy Cam 8MP Brown Night Vision 119436C, Overland Park, Kansas, USA) were used in 2011 to monitor early morning foraging behavior. In 2012, students helped with the dawn observations.

General Production Methods: Greenhouse-grown seedlings were used for all treatments and fertilized with fish emulsion twice before setting out to harden off for five days. Organic nutrient management followed recommendations from soil test results and guidelines from the New England Vegetable Management Guide (Howell and Hazard, 2010. Organic fertilizer (Pro-Gro 5-3-4, North Country Organics, Bedford,VT) was applied during bed construction with a nitrogen rate of $56 \mathrm{~kg} / \mathrm{ha}$. One line of drip irrigation was placed under 1-mil black embossed polyethylene mulch in the planting row.

In 2012, because of early emergence of striped cucumber beetle (Acalymma vittatum), planting rows were covered with ProtekNet (Dubois Agrinovation, Quebac, Canada. Once a good percentage of plants were flowering, covers were removed. To control for striped cucumber beetles after removal of covers, pyrethrin (Pyganic EC) was applied at a rate of $15 \mathrm{ml} / 3.78$ liters. Plants were fertigated every seven to ten days with fish emulsion (Organic Gem 3-3-0.3) at a rate of 47 liters/ha and irrigated at a rate of $2.54 \mathrm{~cm} /$ week. Treatments were scouted weekly for insect pests and diseases. 
Experimental Design and Response Variables: The experimental design consisted of 2 replications per tunnel containing five melon plants from five cultivars, for a total of 50 plants per pollination system. The same five cultivars were used consistently in both years, with the sixth needing replacement for the 2012 season. Cultivar was not tested as a main effect since cultivar response was not a variable of interest. In 2011, each high tunnel had the same test-plot organization. In 2012 each high tunnel test plot was randomized.

Total fruit weight and number per plot were recorded, with cull and marketable fruit data recorded as well. Cull and marketable fruit were determined by size and appearance. Fruit quality was measured by percent soluble solids (sweetness) with a hand-held refractometer following MacGillivray (1947). The first 6-18 fruit (dependent on cultivar) per cultivar to ripen in each plot were used for soluble solids testing. The ground-touching or lower portion of the melon was marked. The melon was halved with measurements taken from the noted lower half. Depending on melon size, 3-6 juice subsamples were used to determine average sweetness per fruit. Nine percent average soluble solids content and above was considered acceptable (Agricultural Marketing Services, 2008).

In 2011, two sunrise observations (last week of June and first week of July) were made to determine which hive began foraging first. In 2012, one sunrise observation was conducted (third week of June). Casual observations were noted throughout the growing season to determine if tunnels interfered with the bee's navigation or access to the crop. These casual observations consisted of observing bee behavior within the high tunnel at various periods of the day. 
Statistical analyses were done using SAS (Release 9.2, 2002-2008, SAS, Cary, NC). An analysis of variance (ANOVA) using PROC GLM was done to test pollination system, and year effects including interactions for all continuous data. If an interaction was significant, main effects were analyzed with the ANOVA procedure with pairwise comparisons using Fisher's protected LSD to reveal differences. All tests were conducted at the $P=0.05$ significance level. Significant statistical tests are detailed in tabular form in the appendix.

\section{Results}

Yields differed greatly between years. Total muskmelon yields (both fruit counts and weight) were greater in 2011 than 2012. Results for both years focus on total fruit count and weight since marketable and cull numbers were affected more by disease and insect damage than pollination system. Total fruit weight, and total fruit count are summarized without grouping by year since there were no significant 2-way interactions. Percent soluble solids, and average fruit size each had significant 2 -way interactions so each is summarized by year.

Total weight: Total weight of fruit represents the average total kilograms of fruit harvested across replications per pollination system. Pollination system x year was not significant, thus there was no significant effect on total weight across pollination systems.

Total fruit counts: When analyzing main effects, there was a marginally significant difference between pollination systems $(\mathrm{p}=0.0570)$ and highly significant differences between years $(\mathrm{p}<0.0001)$. Figure 1 displays average total fruit count by pollination system across years. The tunnel with the honey bee hive did not differ from either of 
the other tunnels, but the bumble bee tunnel differed from the open tunnel (figure 1). 2011 was the more productive year.

Average fruit size: Pollination system x year was significant $(\mathrm{p}<0.05)$. Main effects were analyzed separately by year. In 2011, there were no differences between pollination systems, unlike in 2012 where there were differences between pollination systems ( $\mathrm{p}=0.0008$ ) (figure 2 ). The bumble bee tunnel differed significantly from the open tunnel and the tunnel with the honey bee hive, which did not differ from each other.

Percent soluble solids: Pollination system x year $(\mathrm{p}=0.0003)$ was significant (figure 3 ). Because of this, analyses were done by year. When analyzing main effects by year, no significant differences were found.

\section{Discussion}

A true randomized block design was not feasible with this study because the research farm only had three high tunnels. For this reason, replication of the pollination system was not possible. Total fruit counts and average fruit size differed dramatically between years with 2011 being the more successful year. In 2012, an aphid infestation affected all three tunnels, but had a greater impact on the screened bumble tunnel causing significant differences from the other two pollination systems.

Total weight and fruit counts: 2011 was close to 200 percent more productive than 2012 in total kilograms and 70 percent more productive in fruit produced. It is unlikely differences in cultural practices (watering, fertilizing, etc.) between years were responsible since those practices were done to best support the crop. Each year's negative confounding effects (insect pests and disease) were noted, but not measured 
to be able to detect trends. The open tunnel produced the greatest number of fruit, with the screened bumble house producing the largest fruit in 2011 and the smallest fruit in 2012 (likely an effect from the aphids). The data do not suggest why the north tunnel consistently produced more than the other two pollination systems. Comparing climate data between years poses a challenge since planting dates differed by two weeks. Reviewing one period (end of June to mid-July) shows that average air temperatures were the same ( 24 degrees Celsius) in the open tunnel and screened tunnel (data not available for the open tunnel with honey bees). Average relative humidity had a similar trend. Relative humidity was greater in 2011 by approximately six percent. The screened bumble tunnel had a higher percent relative humidity by approximately 2-3 percent than the open tunnel, but this was not statistically significant.

Average fruit size and percent soluble solids: Fruit were approximately 70 percent larger in 2011 than in 2012. Similarly to fruit weight and count, it is difficult to determine the cause for the reduction in fruit size between years. Percent soluble solids differed significantly between years as well with 2011 producing fruit that was 17 percent sweeter than in 2012. In 2011, average fruit size was greatest and sweetest in the screened bumble tunnel, but smallest and least sweet in 2012. The detrimental aphid infestation in the screened bumble tunnel is likely the reason for the negative productivity and quality. Overall, production may have declined in 2012 because of a severe cucumber beetle infestation, which caused vine decline as well. The aphids, coupled with the striped cucumber beetles, may have had enough of a detrimental effect to cause the dramatic difference in production between years. 
Pollination system observations: This study supports the value of adequate ventilation as a means to provide access to pollination-dependent crops grown under cover, as reported by other studies (Dag and Eisikowitch, 1999; Drost, 2011). This study also suggests that it is not necessary to have commercially-reared hives within high tunnels if a healthy native bee population and/or field hive is present. Kreman et al. (2002) reported that vegetable production in the vicinity of natural habitat supports pollination services of entomophilous crops. The high tunnels in this study were surrounded by natural habitat that would provide native bees with nesting and foraging habitat. High tunnels located in areas without access to natural habitat would likely need managed pollination services. Wild bumble bees and honey bees were observed foraging within the open tunnel without a managed hive. Wild bumble bees were observed foraging in the tunnel with the honey bee hive as well.

Both honey bees and bumble bees showed signs of disorientation within the high tunnels (continually flying into the covered ceiling or edges of the high tunnel). For the honey bee pollination system, the ridge vent did provide eventual exit from the tunnel, but its use was more coincidental than deliberate. Bumble bees were more often seen attempting to find exit at the side vents, which were screened. Ultraviolet light plays an important role in influencing a bee's vision and orientation, especially in guiding bees to nectar sources (referred to as corolla nectar guides) (James and PittsSinger. 2008). Studies have shown that both honey bees and bumble bees prefer foraging in areas exposed to direct sunlight versus foraging in areas that block ultraviolet light (Fisher and Pomeroy, 1989; Morandin et al., 2002). The plastic covering used on the high tunnels in this study were UV-blocking so the resulting 
effect on navigation is not unexpected. Morandin et al. (2002) reported that while bumble bees preferred direct sunlight and UV-transmitting plastics, UV-blocking plastics did not interfere with successful pollination behavior. Both bee species have demonstrated the ability to adapt to the lack of ultraviolet light, with bumble bees being the most adaptive (James and Singer-Pitts, 2008).

Placement of the honey bee hive inside the tunnel did not cause the honey bees to begin foraging earlier in the morning than the outside hive, especially within the high tunnel. In a dawn observation session I made on a clear morning (early July 2011), the outside honey bee hive became active (bees entering and exiting the hive) 35 minutes before the high-tunnel hive (4:55 am versus 5.30 am). At 5 am, air temperatures at hive landing height for the hive inside the high tunnel and outside were both 15 degrees Celsius. In 2011, dawn observations initially were done on a humid, cloudy morning (late June); it had rained during the night. The outside hive was still active earlier than the inside hive. By 6am the outside hive was very active compared to 6:23 am for the inside hive which had less activity. I arrived too late to note exact time of activity for the outside hive. The inside hive had a lot of activity on the landing, but no exit or entry prior to 20 minutes after 6 am.

In 2012, dawn observations focused more on pollination activity within the high tunnel with the honey bee hive than actual concentration of movement from the hive since the previous year's observations within the high tunnel revealed the honey bees left the tunnel to either scout or forage at dawn instead of remaining within the high tunnel. Muskmelon flowers opened after bee activity began. Temperature at approximately 6 am inside the high tunnel with the honey bee hive was 21 degrees 
Celsius. Honey bees were exiting the high tunnel more than remaining in it to explore the high tunnel crops. Wild bumble bees began pollinating within the high tunnel before honey bees. In general, observations made both years of honey bee behavior revealed that at dawn movement within the high tunnel was clumsy (bumping into the plastic until exit was found or returning to the hive) if the bee remained under the plastic. These observations suggest the importance of natural light to successful orientation to honey bee dawn foraging behavior more so than air temperature. James and Pitts-Singer (2008) noted that under UV-blocking coverings bee activity was delayed when compared to coverings without a UV filter. Exact levels throughout day are not known for the type of plastic used in this study.

In both years, the bumble bees began exiting the hive before first light. Bumble bees first visited cherry tomato plantings within the high tunnel and then visited muskmelon flowers, even attempting to visit closed flowers. Compared to honey bees, bumble bees are more tolerant of cool temperatures (Iselin et al., 1974), and less confused by low UV levels (James and Pitts-Singer, 2008). The observations made in this study suggests that screening commercially-reared bumble bees in a high tunnel is likely not necessary since entry and exit of the side-vented tunnels was utilized by wild bee populations in both open tunnels. Also, decreased air ventilation caused plants to grow more than necessary and limited entry of insect predators, but allowed smaller-bodied insect pests—-like aphids— entry. As reported by Kreman et. al (2002), these results suggest that use of a commercial bumble bee hive for supplemental pollination systems within an open high tunnel is not necessary if a healthy population of native bees or a field hive is present. Also, Fisher and Pomeroy 
(1989) studied use of bumble bees within for greenhouse production of muskmelon and observed that up to 32 percent of bumble bees left the greenhouse through ventilation gaps to forage elsewhere. In this study, screening and closing ventilation gaps reduced escape of bumble bees, but did not eliminate that behavior.

Muskmelons are dependent on bee pollination for marketable yields (Iselin et al., 1974; McGregor et al. 1965; Mussen and Thorp, Publication 7224). Evaluating yield response by the different pollination systems revealed that the pollination systems were equally effective at producing a marketable crop. In 2012, the screened bumble house failed to produce a marketable crop because of a devastating aphid outbreak, but yields were much lower in the other two pollination systems as well. If commercially-reared bumble bees are housed in this manner to deter escape, diligent insect pest scouting is advised. The presence of a honey bee hive within the high tunnel did not cause an increase in total fruit production when compared to the open high tunnel without a hive.

\section{Conclusion}

The Gothic-styled high tunnels did not hinder effective pollination of muskmelon. Honey and bumble bees used side vents and endwall entries more so than the ridge vents. Ridge vents did allow for haphazard exit and escape of heated air. High heat can negatively affect pollination (James and Pitt-Singer, eds., 2008). Growers in southern New England are likely located in areas with ample natural habitat that houses resident bees. These natural pollination services allow growers to eliminate the managed-hive expense. Considering the effects of screening on plant growth and possible pest outbreaks, if foraging and nesting habitat are not present, 
renting a honey bee hive would be a better option than purchasing a bumble bee hive. Further study on resident bee populations that visit high tunnels is worthwhile. 


\section{References Cited}

Agricultural Marketing Services, 2008. U.S. Department of Agriculture. United States standards for grades of cantaloupes. 5 May 2012. < ww.ams.usda.gov/AMSv1.0/ getfile?dDocName=STELPRDC5050255>

Blomgren, T. and T. Frisch. 2007 High tunnels: using low cost technology to increase yields, improve quality, and extend the season. Cornell Coop. Ext. 3 Jan 2012. <http://www.uvm.edu/sustainableagriculture/hightunnels.html>

Dag, A. and D. E. Eiskowitch. 1999. Ventilation of greenhouses increases honey bee foraging activity on melon, Cucumis melo. J. Apicul. Research. 38:169-175.

Drost, Dan. 2011. High Tunnel summer squash production. Utah State Unv. Coop. Ext. 13 Jan 2013<http://extension.usu.edu/files/publications/publication/Horticulture _HighTunnels_2011-01pr.pdf>

Fisher, R.M., and N. Pomeroy. 1989. Pollination of greenhouse muskmelons by bumble bees (Hymenoptera: Apidae). J. Econ. Ent. 82: 1061-1066.

Iselin, W.A., M.H. Jensen, and H.G. Sprangler. The pollination of melons in air inflated greenhouses by honey bees. Environ. Ent. 3:664-666.

James, Rosalind R. and Theresa L. Pitts-Singer, eds. 2008. Bee pollination in agricultural ecosystems. New York: Oxford Univ. Press.

Jett, L.W. 2006b. Galia muskmelons: A potentially profitable early-season crop for high tunnels in the Central Great Plains. Unv. Missouri Coop. Ext. Ser. 2 Jan 2013 < http://www.hightunnels.org/PDF/JETT\%20Production\%20Melons.pdf> 
Kremen, C., N.M. Williams, and R.W. Thorp. Crop pollination from native bees at risk from agricultural intensification. PNAS. 99:16812-16816.

McGregor, S. E., M. D. Levin, and R. E. Foster. 1965. Honey bee visitors and fruit set of cantaloups. J. Econ. Ent. 58:968-970.

Mussen, E. C. and R. W. Thorp. Honey bee pollination of cantaloupe, cucumber and watermelon. Univ. Cal., Davis: Coop. Ser. Ext. Bul. 7224 


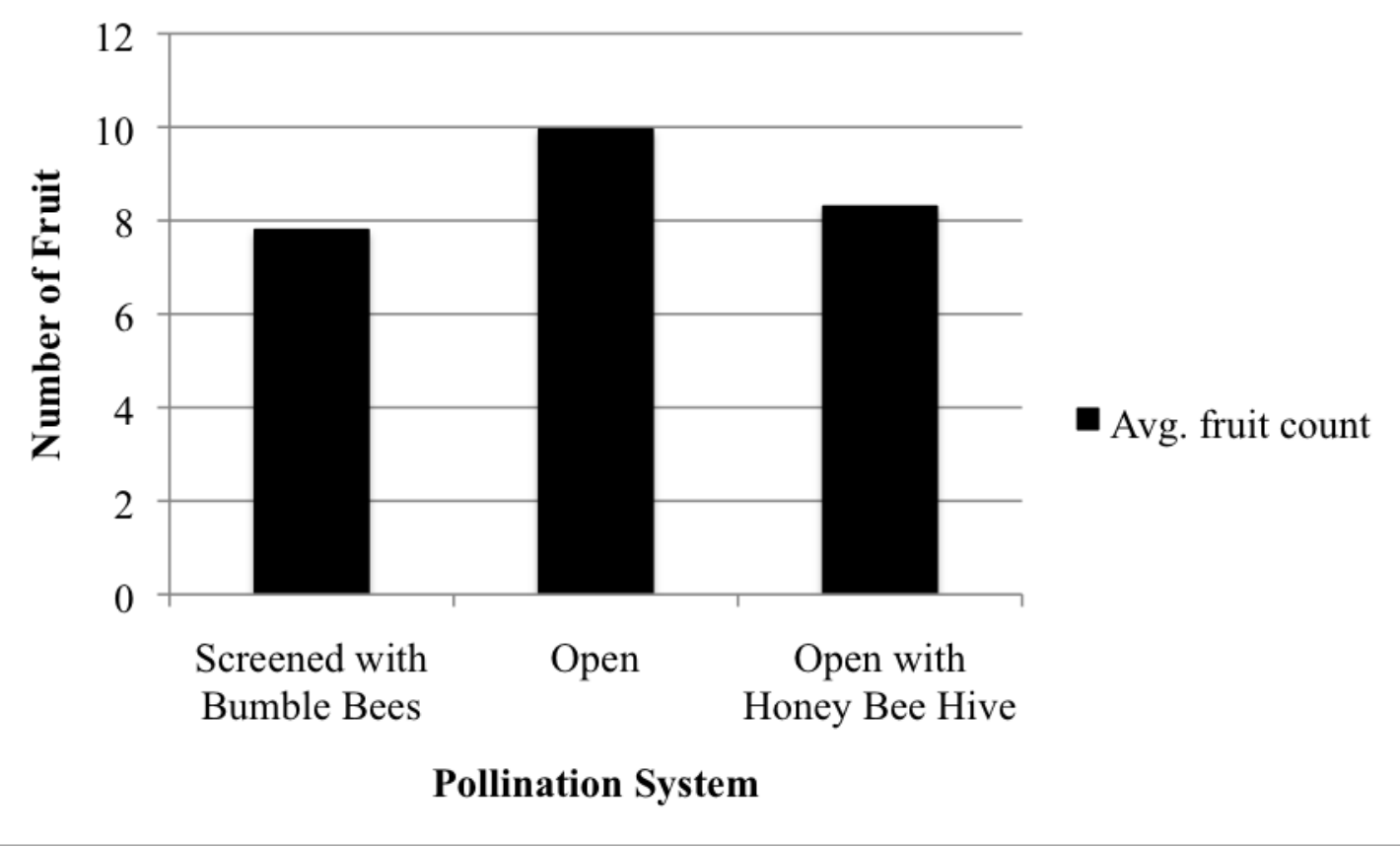

Figure 1. Mean total fruit count across 10 replications per each pollination system. 


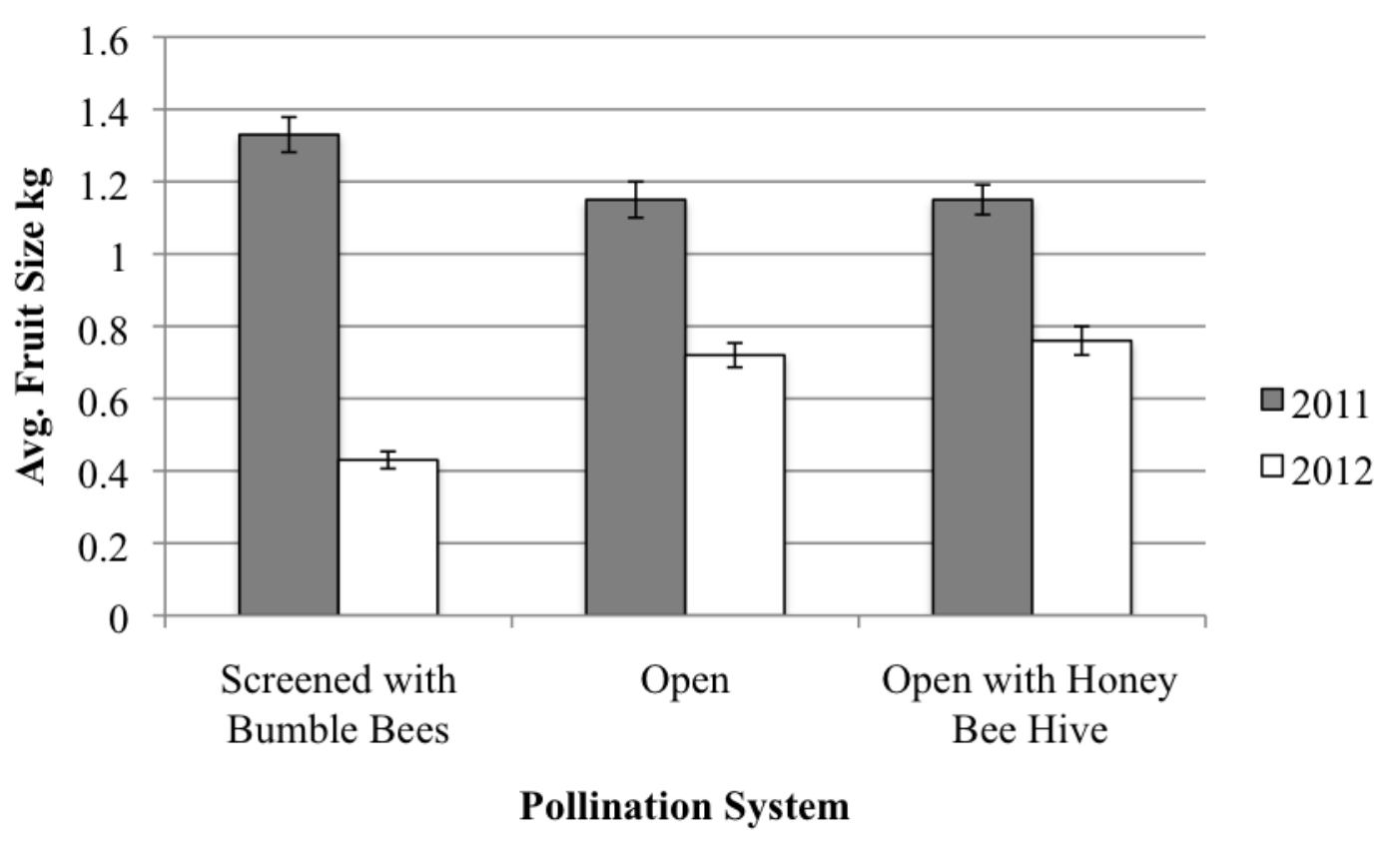

Figure 2. Average fruit size differed significantly between years. In 2012, the screened bumble bee tunnel differed significantly from the open and open with honey bee hive pollination systems $(\mathrm{p}<0.05)$. Average fruit size is across 10 replications per pollination system. Bars represent $\pm \mathrm{SE}$. 


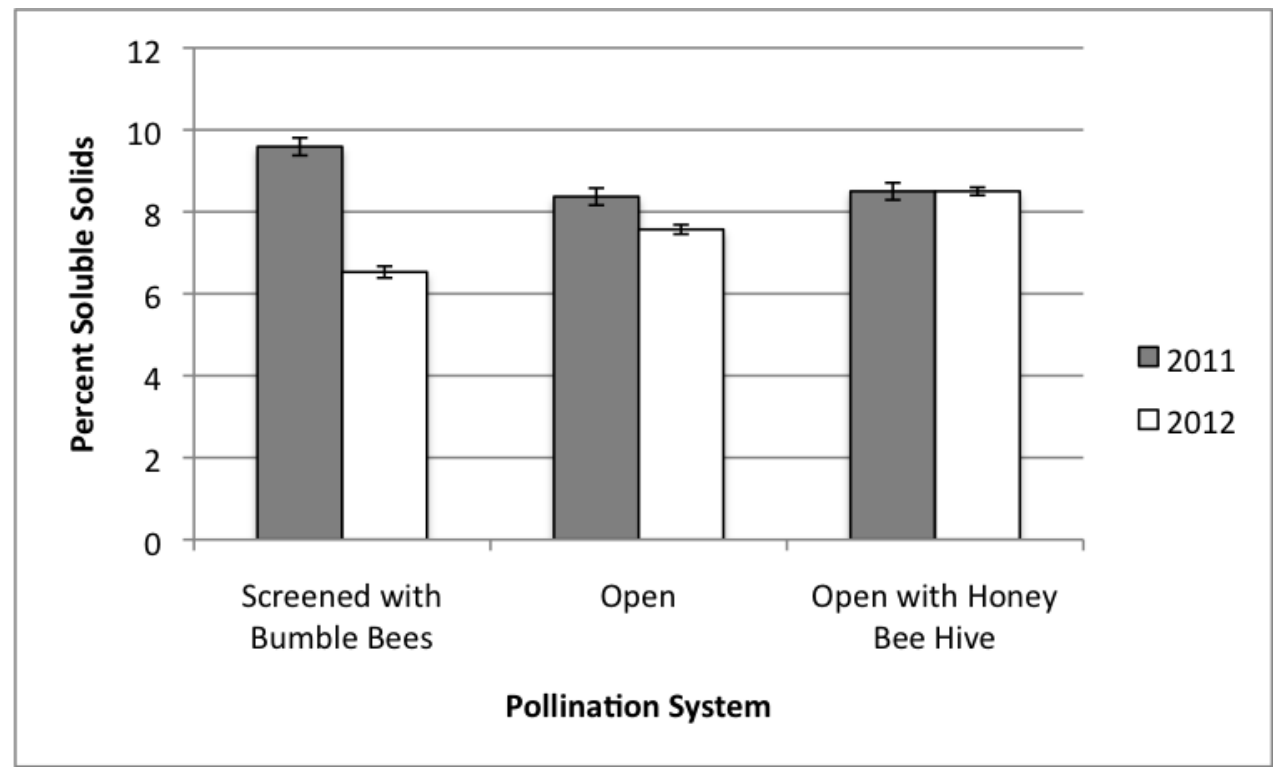

Figure 3. Average $(n=10)$ percent soluble solids per pollination system. Pollination system x year was significant $(\mathrm{p}<0.05)$. Bars represent $\pm \mathrm{SE}$ 


\section{Chapter 4}

Chapter 4 has been formatted for the submission to HortScience.

\section{Consumer Preference for Locally Grown Muskmelon: A Conjoint Analysis of Willingness-to-pay and Taste Preference in Rhode Island.}

\section{Mina Vescera}

Masters Candidate, Department of Plant Sciences and Entomology, University of Rhode Island, Kingston, RI 02881. Email: mina.vescera@ gmail.com

Rebecca Nelson Brown ${ }^{3}$

Associate Professor, Department of Plant Sciences and Entomology, University of Rhode Island, Kingston, RI, 02881. Email: Brownreb@uri.edu

\footnotetext{
${ }^{3}$ Corresponding author and for reprints email Rebecca N. Brown: Brownreb@uri.edu
} 


\section{Introduction}

The local food movement has greatly benefitted small farms and is directly linked to the demands of local consumers (Darby et al., 2008). Farmers' markets have played an important role in the local food movement by allowing growers the benefit of direct-to-consumer sales and connecting consumers with their growers. It is important for growers to meet demand for fresh, local produce and maintain consumer interest. Providing a diverse selection of produce throughout the growing season allows growers to remain competitive with other sources of fresh produce, e.g. supermarkets, and maintain consumer loyalty (Bond et al., 2006).

The purpose of this study was to evaluate consumer preference for locally produced muskmelon, which is a high-value crop not commonly grown in southern New England. Measuring consumer preference for a new product is a tool that producers use to gauge production. Recent consumer trends reveal increased demand for a greater variety of fruits and vegetables, and that quality and variety are expected at local farmers' markets (Bond et al. 2006). Consumers value locally produced foods because local products are perceived to be higher quality, to have an increased nutritional value, and to be produced with best management practices (Martinez et al. 2010).

Production systems in New England differ from the large-scale industrial production systems of commercial farming common to other regions. Since 2002, New England has experienced an increase in small farms (sales $<\$ 250,000$ ) and the majority of these farms produce for direct-to-consumer sales (USDA 2007). 
Addiotionally, New England ranks within the top ten nationally in direct-to-consumer sales (Diamond and Soto, 2009).

High and low tunnels play an important role in allowing growers in cold climates to provide a diverse selection of fresh produce for an early and extended growing season (Lamont, 2009). Differences in economies of scale and land values in New England make it difficult for small farms to compete with commercial production pricing (Sassanrath et al., 2010). The potential for early or seasonal production of high-value crops such as muskmelon is valuable to local growers because it allows them to price their crop at a premium while competing with outside markets, and provides local consumers with specialty cultivars that are not available in local supermarkets. Muskmelon, referred to as cantaloupe, is a common supermarket staple, but not commonly available at farmers' markets. Mayen and Marshall (2005) reported that local branding of a cantaloupe product allowed for a competitive advantage over nationally-branded cantaloupes.

This study sought to explore four questions: (1) What are consumer purchasing habits of cantaloupe and would they consider purchase of local cantaloupes? (2) How often and why do consumers frequent farmers' markets; (3) Would consumers be willing to pay more for locally-grown cantaloupes? (4) Which cantaloupe (local or supermarket) do consumers prefer and why?

\section{Methods}

Survey: A survey was conducted at three Rhode Island farmers' markets in August 2012 to gather information about cantaloupe purchasing habits of consumers and their willingness to pay for local cantaloupe. The first section of the survey (the 
questionnaire) is pictured in figure 1. Additionally, a Ablind taste test was included as part of the survey; this involved a test between locally-grown cantaloupes and those purchased at the supermarket. The purpose of the taste test was to understand what attributes consumers value. In particular, I was interested in learning if consumers always chose the sweeter sample. Sweetness is an important quality measurement for cantaloupes (Agricultural Marketing Services, 2008), but other melon attributes may affect preference as well. Figure 2 details the taste test questions with the attributes listed. A total of 102 surveys were collected.

At each farmers' market, a booth was used to hold the taste test and conduct the questionnaire. Signage was posted at the booth to promote this effort and pique consumer curiosity. Consumers were not solicited to partake unless they approached the booth. Interested participants were asked to fill out the first portion of the survey (first five questions) and then were given melon samples labeled $\mathrm{A}$ and $\mathrm{B}$ for the taste test. The taste test consisted of two trials. After each melon sample, participants were directed to cleanse their palate with water. Each participate was asked to choose which melon sample they preferred (A or B), or if they had no preference (indifferent). Participants were then asked to choose which attribute was the most important in determining their choice. Attributes listed were: sweetness, texture, color, tartness, other (with fill-in space available), and indifferent. Lastly, they were asked to choose how much more they would be willing to pay for their preferred melon over the melon they did not prefer. Amounts were listed as percents and were as follows: zero or no preference, $10,25,50,75$, and 100 percent or more. 
Local melons were produced at the University of Rhode Greene H. Gardener research farm. Three melon cultivars were used to represent the local melons, and one cultivar was used to represent the supermarket melon. Locally-produced melons were grown using low tunnels and organic farming practices. Supermarket melons were grown conventionally for commercial production in another region. The cultivar is unknown, but type was western shipper. Table 1 lists cultivars, percent soluble solids, and farmers' markets attended.

Population: The subject population consisted of people that attend farmers' markets and support local vegetable production. Three farmers' markets located in Rhode Island served as test locations. Two were located in Providence neighborhoods and one was located in suburban Rhode Island. The two in Providence were the Neutaconkanut Market located in the neighborhood of Silver Lake, and the Armory market located in the West End neighborhood. Silver Lake is approximately 50 percent Caucasian, 40 percent Hispanic, and nine percent African American, and the West End is approximately 50 percent Hispanic, 26 percent Caucasian, and 18 percent African American (Prov. Plan). The median household income is $\$ 28,000$ for Silver Lake, and \$21,500 for the West End. The Coastal Growers Market, in Saunderstown, is predominantly Caucasian (94 percent) with a median household income of $\$ 51,000$, and is located in a comparatively rural area (US Census, 2010). Each location was chosen to include people from a range of socio-economic backgrounds, but choices were limited by the availability of market booth space.

Experimental Design and Statistical Analysis: The distribution goal at each farmer's market was thirty with a maximum of fifty surveys. Distribution of the 
surveys was randomized. The questionnaire portion (questions 1-5) was not randomized, but had the same order for each survey. The taste test portion of the survey utilized randomization of melon sample paths and dissimilar trials. For the first sample set there were three possible trials: supermarket versus supermarket, cultivar 2 versus cultivar 1 , and cultivar 1 versus cultivar 1 . The second sample set consisted of a supermarket sample against a local sample (cultivar 1 or 2 ). The various trial combinations allowed for six possible sample paths with each path having five replications. Any dissimilar trial was randomized as well so as not to remain consistent per sample path. For example, path 1 consisted of supermarket versus supermarket for the first trial, but for the second trial supermarket versus cultivar 1 could have two possible orders (supermarket versus cultivar 1, or cultivar 1 versus supermarket). The trials consisting of the same melons acted as controls. Only supermarket and cultivar one ("Athena") were used for control trials. A total of 102 surveys were collect with 204 taste-test trials. Unanswered questions were noted as blank when recording data. Answers to questions were assigned a number and recorded. Data from all markets were pooled. Observations were recorded as panel data and summarized. Willingness-to-pay data were analyzed with fixed effect regression analysis, with the fixed effect being the participant's taste bias. The logit model was used to test if consumers were successful with at choosing the sweeter melon. Odds ratios were manually calculated. Statistical tests were conducted with Stata 10.0 (College Station, Texas, USA). All tests were conducted at the $P=0.05$ significance level. 


\section{Results and Discussion}

Questionnaire Results: Participants were asked to choose one answer per question unless specified otherwise. This request was not always followed so many questions had more than one answer checked. It may be best to note with each question what is expected of the participant. Forty three percent of participants purchase cantaloupe year round, with 46 percent purchasing only during the summer. Most (52 percent) people purchased cantaloupes at the supermarket, with 26 percent purchasing from the supermarket and farmers' markets. Forty-one percent shopped at farmers' markets once per week, and 29 percent shopped twice per month. The options "rarely" (1-2 times/summer) and "once a month" were chosen by a third of participants. The majority (63 percent) of participants shopped at farmers' markets to support local farmers, and for quality and variety of the produce available. Fifty-eight percent of participants would consider purchasing local melons from their farmers' market at a higher price than supermarket, whereas 19 percent would only purchase local melons if at or below supermarket prices. Very few (9 percent) participants would purchase local melons only if organic, while 10 percent would only consider paying more than supermarket prices if the locally-grown melon was organic.

These experimental results are similar to other studies testing consumer preference for agricultural goods. A consumer survey of more than 300 farmers' markets attendees in New Jersey revealed that the majority ( 98.5 percent) expected higher quality from their farmers' markets than other retail facilities, with supermarkets being the most popular (Govindasamy et al., 2006). Govindasamy et al. (2006) also reported that more than half of participants expected greater variety from 
farmers' market than elsewhere. Similar to this study's survey, organic produce was not valued more than local supply of fruits and vegetables. Some participants of my survey questioned the production methods of both sample melons, but no one refused to participate when told neither melon was certified organic. From a Kentucky study done on blueberries, Hu et al. (2009) reported that consumers valued the organic label, but the local label was valued more.

In this study, after each melon taste test participants were asked to choose how much more they would be willing to pay for their preferred melon sample. A total of 203 observations were used to test willingness-to-pay estimates. Sixty-five percent of participants chose to pay between 10 to 25 percent more per pound for their preferred melon over the melon they did not choose. A fixed effect regression model was used to test if their stated willingness-to-pay amounts could be predicted by melon sweetness and other preferred melon quality traits. I hypothesized that unit (by percent soluble solids) differences in sweetness between samples would influence the participants choice in that tasting the sweeter melon first could potentially predict the participants' preferences, or a substantial difference in sweetness and order could have the same effect. Thus, percent soluble solids differences between melon samples acted as the explanatory variable. It is important to explain percent soluble solids differences and how they were tested in the models. The smallest difference between samples was zero from the control trials of test one, and the largest difference was 6.75 percent. The supermarket samples were always the sweetest melon samples used. I hypothesized that large differences in sweetness between samples would positively affect choice. Since order of melon samples was randomized, the difference in melon 
sweetness between samples could have a negative or positive sign associated with it depending on order. Thus, when configuring the model, only the actual difference and the difference cubed could be used so as to retain the proper sign, since squaring the difference would lose the sign. Losing the sign would remove the order of sweetness from the equation.

Preferred attributes chosen (sweetness, texture, etc.) were included as covariates. Fifty percent of participants chose sweetness as the most important attribute. About 16 percent chose texture, with 17 percent choosing texture and sweetness as the most influential attributes. Control covariates (trial consisting of the same melon) were tested as well.

None of the willingness-to-pay models tested were significant (both robust and bootstrap standard errors were used) (table 2). With these results, percent soluble solids and participants' stated preferences had no relationship to their willingness-topay estimates. Also, participants were prone to failing the control trials. For test one, participants were only 26 percent effective at choosing the sweeter melon or recognizing an absence of difference. For test two, participants were more likely (59 percent) to choose the sweeter melon; however, test two did not employ controls. When faced with controls, participants were more successful at correctly recognizing an absence of difference if the test consisted of cultivar 1 ( 22 percent) versus the supermarket melon (16 percent), though these results are not significant.

Stated preferences may not always be an accurate reflection of consumer behavior (List et al., 2006; Lusk 2003). The survey topic, wording of survey questions and choices may cause participants to exaggerate or impress an expected 
outcome versus a true personal preference. Dickie et al. (1987) stated that participants may not have incentive to reveal their true preference with hypothetical responses. In a survey conducted in Ohio, Darby et al. (2008) reported that direct market shoppers were willing to pay twice the value of out-of-region strawberries for local strawberries. In South Carolina, Carpio and Isengildina-Massa (2009) reported that consumers were willing to pay a 27 percent average premium for local produce and the majority (78 percent) stated that homegrown products are the same or better than products from other states. Though consumers express a preference for local goods, this study's results can only suggest that consumers would be willing to pay more for local melons. Results Responses to the questionnaire suggest that consumers highly value availability of local produce, and more than 75 percent would prefer to purchase melons at their farmers' markets rather than at their supermarket.

The logistic regression model was used to test if participants could detect quality, or identify the sweeter melon, between the samples. Since participants chose sweetness as the most important attribute in choosing their preferred melon, it was important to test if they could actually perceive this quality. Three explanatory variables were included in the model: (1) differences between melon sweetness (both actual difference and cubed differences), (2) if the sweeter melon being the first sample affected choice, and (3) the effect of the control sample. The logistic regression table is detailed in table 3. On average, participants chose the sweeter melon 49 percent of the time. The order of melon sweetness within samples was not significant. This implies that the palate cleanser was effective. Actual sweetness difference was significant suggesting that with each unit increase in percent soluble 
solids, participants were 18 percent more likely to choose the sweeter melon $(\mathrm{p}<0.0001)$. As sweetness differences became large between samples this effect was diminished $(\mathrm{p}<0.0001)$. If participants were faced with the control sample, they were less likely to choose indifferent by a factor of 31 percent about the mean. Only the actual difference in sweetness between melon samples had an odds ratio greater than one (1.20).

Natural variation in percent soluble solids exists throughout the entire melon, (MacGillivray, 1947). Sweetness is greater near the center of melon and less closer to the rind. The difference can vary by 1 percent or less depending on the cultivar and ripeness. It would be worthwhile to conduct the test to control for this variation. Also, the local melons were nearing the end of their harvest and this affected percent soluble solids. Plants were in decline and thus less able to translocate sugars to the fruit.

\section{Conclusion}

These results suggest that consumers who frequent farmers' markets in Rhode Island would likely purchase locally-grown cantaloupe. Only three percent of participants expressed disinterest in purchasing locally-grown cantaloupe. Even though results for willingness-to-pay estimates were insignificant, growers are usually adept at deciding how much to charge for their product and still remain competitive. Also, consumers expressed a strong support for local production of cantaloupe. Considering the supermarket melons were of excellent quality (percent soluble solids near 11 percent and greater), local growers should consider the timing of planting and cultivar carefully. Having a crop of early- to late-season melons may greatly benefit 
the grower's ability to compete with outside markets while offering an interesting and diverse selection of cantaloupes not available in supermarkets. 


\section{References Cited}

Agricultural Marketing Services, 2008. U.S. Department of Agriculture. United States standards for grades of cantaloupes. 5 May 2012. < ww.ams.usda.gov/AMSv1.0/ getfile?dDocName=STELPRDC5050255>

Bond, J.K., D. Thilmany, and C.A. Bond. 2006. Direct marketing of fresh produce: Understanding consumer purchasing decisions. Choices. 21:229-2236.

Carpio, C.E., and O. Isengildina-Massa. 2009. Consumer willingness to pay for locally grown products: The case of South Carolina. Agribusiness. 25: 412-426.

Darby, K., M.T. Battie, S. Ernst, and B. Roe. 2008. Decomposing local: A conjoint analysis of locally produced foods. Amer. J. Agr. Econ. 90: 476-486.

Diamond, A. and R. Soto. 2009. "Facts on Direct-to-Consumer Food Marketing: Incor-portating Data from the 2007 Census of Agriculture. U.S. Depart. of Agricul. Agriculture Marketing Ser.: Washington. Accessed 15 May 2012. <http://www.ams.usda.gov/AMSv1.0/getfile?dDocName=STELPRDC5076729>

Dickie, M., A. Fisher, and S. Gerking. 1987. Market transactions and hypothetical demand data: A comparative study. J. Amer. Stat. Assc. 82: 69-75.

Dimitri, C., A. Effland, and N. Conklin. 2005. The $20^{\text {th }}$ century transformation of U.S. Agriculture and farm policy. U.S. Dept. Agri. Econ. Resch. Ser. Econ. Info. Bltn. 3. Accessed 3 Feb 2013. < http://ageconsearch.umn.edu/bitstream/59390/2/eib3.pdf> Hu, W. T. Woods, and S. Bastin. 2009. Consumer acceptance and willingness to pay for blueberry products with nonconventional attributes. J. Agri. Appl. Econ. 41: 47-60. 
Lamont, Jr., W.J. 2009. Overview of the use of high tunnels worldwide. 19:25-

29.Lusk, J.L. 2003. Effects of cheap talk on consumer willingness-to-pay for golden rice. J. Agri. Econ. 85: 840-856.

Martinez, S., M. Hand, M. Da Pra, S. Pollack, K. Ralston, T. Smith, S. Vogel, S. Clark, L. Lohr, S. Low, and C. Newman. 2010. Local food systems: Concepts, impacts, and issues. USDA. Econ. Res. Ser. Report No. ERR-97. Accessed 10 May 2012. < http://www. ers.usda.gov/publications/err-economic-research-report/ err97 .aspx\#.UbNkCfbTXiM >

Mayen, C. and M.I. Marshall. 2005. Consumer preference for a fresh-cut melon product-A potential value added product for melon growers. Accessed 12 Feb 2013. <https://www.ifama.org/events/conferences/2005/cmsdocs/1140_Paper_Final. pdf>

MacGillivray, J.H. 1947. Soluble solids content of different regions of watermelons. Plant Physiol. 22:637-640.

The Providence Plan. Providence Neighborhoods Plans. Sliver Lake and West End. Accessed 9 June 2013. < http://local.provplan.org/profiles/\# > Sassenrath, G.F., J.M. Halloran, D. Archer, R.L. Raper, J. Hendrickson, P.Vadas, and J. Hanson. 2010. Drivers impacting the adoption of sustainable agricultural management practices and production systems of the Northeast and Southeast United States. J. Sust. Agri. 34: 680-702.

U.S. Census Bureau. 2010. American Fact Finder: North Kingston town, Washington County, Rhode Island. Accessed 9 June 2013. < http://factfinder2. census.gov/faces/tableservices/jsf/pages/productview.xhtml?src=bkmk >U.S. 
Dept. of Agriculture (USDA). 2007. U.S. Census of Agriculture. "Small Farms Fact Sheet." USDA: Washington. Accessed 20 May $2012<$ http://www.agcensus.usda .gov/Publications/2007/Online_Highlights/Fact_Sheets/Farm_Numbers/small_farm.pd f > 
Table 1. Percent soluble solids associated with cantaloupe type and farmer's market. Markets are organized by order of occurrence. Two cultivars were used for "cultivar 2" because marketable "Sarah's Choice" cantaloupes were no longer available for the Armory Market.

Percent Soluble Solids

\begin{tabular}{lcccccc|}
\hline \multirow{2}{*}{ Market } & \multicolumn{2}{c}{ Local Melon } & & & & Cultivar 1 \\
& Cultivar 1 & Cultivar 2 & SuperMarket & $\begin{array}{c}\text { Surveys } \\
\text { Distributed }\end{array}$ \\
\hline \multirow{2}{*}{ Coastal } & Athena & Sarah"s Choice & 8.41 & 7.92 & 10.75 & 50 \\
Neutaconkanut & Athena & Sarah"s Choice & 10.25 & 6.5 & 13.25 & 20 \\
Armory & Athena & Tasty Bites & 9.75 & 9.0 & 13.0 & 32 \\
\hline
\end{tabular}


Table 2. Willingness-to-pay fixed effects regression model.

\begin{tabular}{lcccc}
\hline $\begin{array}{c}\text { Explanatory } \\
\text { variable }\end{array}$ & Coefficients & $\begin{array}{c}\text { Robust Std. } \\
\text { Errors }\end{array}$ & $\mathrm{t}$ & $\mathrm{P}<|\mathrm{t}|$ \\
\hline delta $^{\mathrm{z}}$ & 0.00 & 0.00 & -0.029 & 0.776 \\
same_melon $^{\mathrm{y}}$ & -0.03 & 0.03 & -1.02 & 0.311 \\
a_sweeter $^{\mathrm{x}}$ & -0.03 & 0.25 & -1.03 & 0.306 \\
\hline
\end{tabular}

${ }^{\mathrm{z}}$ delta represents the actual sweetness difference between percent soluble solids values.

${ }^{\mathrm{y}}$ same_melon represents trials that consisted of the same culitvar per sample.

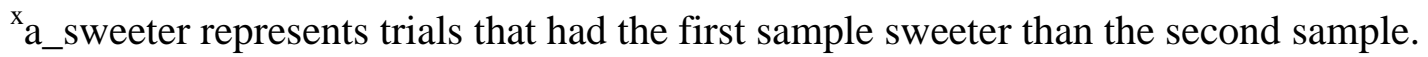


Table 3. Logistic regression model for quality.

\begin{tabular}{lccccc}
\hline $\begin{array}{c}\text { Explanatory } \\
\text { variable }\end{array}$ & Coefficients & $\begin{array}{c}\text { Bootstrap } \\
\text { Std. Errors }\end{array}$ & $\mathrm{t}$ & $\mathrm{P}<|\mathrm{z}|$ & $\begin{array}{c}\text { odds } \\
\text { ratio }\end{array}$ \\
\hline delta $^{\mathrm{z}}$ & 0.18 & 0.19 & 9.72 & 0.000 & 1.2 \\
delta3 $^{\mathrm{y}}$ & 0.00 & 0.00 & -4.35 & 0.000 & 0.998 \\
same_melon $^{\mathrm{x}}$ & -0.31 & 0.07 & -4.63 & 0.000 & 0.730 \\
a_sweeter $^{\mathrm{W}}$ & -0.05 & 0.07 & -0.71 & 0.048 & $\mathrm{X}$ \\
\hline
\end{tabular}

${ }^{\mathrm{z}}$ delta represents the actual sweetness difference between percent soluble solids values

${ }^{\mathrm{y}}$ delta3 represents the cubed percent soluble solids difference between samples.

${ }^{\mathrm{x}}$ same_melon represents trials that consisted of the same culitvar per sample.

${ }^{\mathrm{w}} \mathrm{a} \_$sweeter represents trials that had the first sample sweeter than the second sample. 
The purpose of this survey is to obtain information for local farmers on consumer preferences at farmer's markets, and in particular, on the sale of locally-produced cantaloupes.

Please check one box per question unless otherwise noted.

1. When/how often do you eat cantaloupe?

$\square$ year-round $\quad \square$ summer only $\quad \square$ rarely to never

2. Where do you usually buy your cantaloupes?

$\square$ supermarket $\quad \square$ farm stand/farmer's market

$\square$ grow my own $\square$ all of the above

3. How frequently do you attend farmer's markets?

$\square$ rarely (1-2 times/summer) $\square$ once a month

$\square 2+$ times per month $\quad \square$ every week

4. Why do you shop at farmer's markets? Please check all that apply.

$\square$ to support local farmers $\square$ quality/freshness of the produce

$\square$ variety of produce available $\square$ other

5. Would you purchase locally-grown cantaloupes at your farmer's market, if available?

$\square$ no/not interested $\quad \square$ only if organic

$\square$ only at or below supermarket prices (per lb.)

$\square$ I would consider a purchase at prices higher than at the supermarket (per lb.)

Figure 1. The first page of the survey administrated at each farmer's market. 


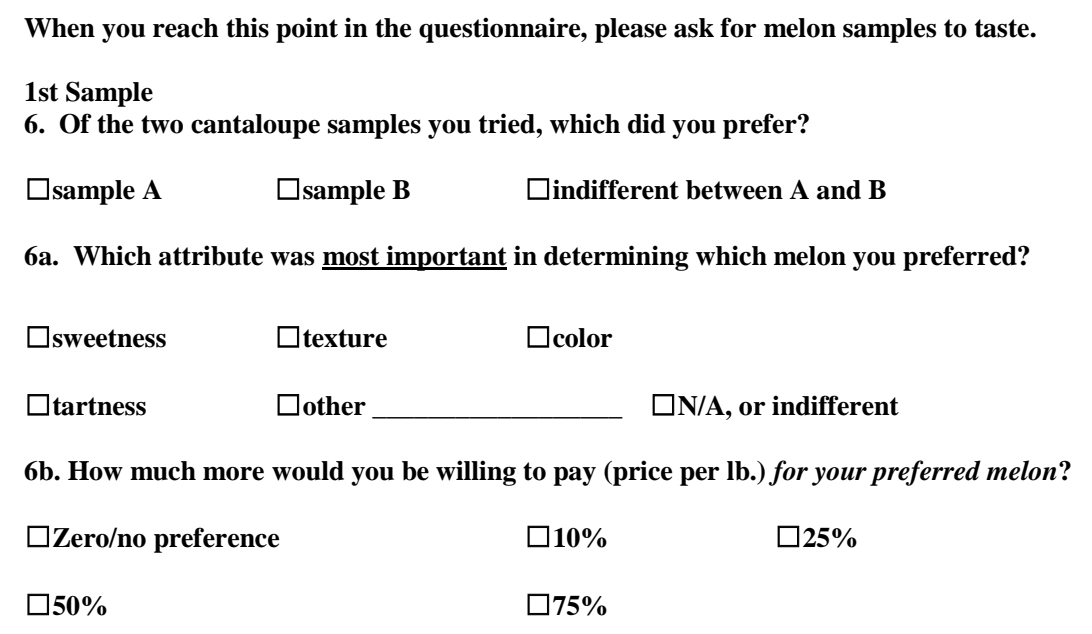

Figure 2. The second portion of the survey consisted of a taste test between two cantaloupe samples designated as sample A and B. The same questions were used for the second sample. 


\section{CONCLUSION}

The results of this study support the potential for growers to successfully produce muskmelon in southern New England. The enhanced growing environment provided by tunnel systems allows for season expansion and diversified production. The incorporation of tunnel systems, both high and low tunnels, is a valuable tool that enables growers to meet consumer demand for fresh, local produce.

Based on the results of this study, low tunnels are the recommended production system to grow muskmelon in southern New England. In both years, the system consistently produced greater total yields, fruit quantity, and fruit quality when compared to the high tunnel and control systems. The high tunnel system had the advantage over low tunnels of being able to produce early yields because of enhanced soil-heating capabilities and a dry environment that allowed for flexibility in bed preparation. The cultivar 'Sarah's Choice' had the most consistent quality regardless of production system. 'Sivan' is not recommended for high tunnel production because of its poor performance during both years of the study.

The Gothic-styled high tunnels did not hinder pollination of muskmelon.

While screening the bumble bees within the high tunnel allowed for yield comparisons against the other pollination systems it also posed aphid infestation issues. Growers in southern New England located in areas with ample natural habitat would likely benefit from natural pollination services eliminating the managed-hive expense. If natural habitat is not available, renting a honey bee hive would be a better option than a bumble bee hive. The majority of survey participants stated that they would purchase locally-grown muskmelons from their farmers' markets. Sweetness was the most 
important attribute in choosing their preferred melon sample. Willingness-topay estimates were unreliable; however, participants were adept at correctly choosing the sweeter melon sample, unless faced with a control trial.

Overall, these results provide growers with encouraging results that support the production of different melon cultivars rarely offered at the farmers' markets. Further production system studies on muskmelon cultivars suitable for the region are recommended 


\section{APPENDIX}

Chapter 2

\begin{tabular}{|c|c|c|c|c|c|}
\hline \multicolumn{5}{|c|}{ SAS, GLM Procedure: First Day of Harvest ANOVA test 2011} & \multirow[b]{2}{*}{$\operatorname{Pr}<\mathrm{F}$} \\
\hline Source & $\begin{array}{l}\text { Degrees of } \\
\text { Freedom } \\
\text { (DF) }\end{array}$ & $\begin{array}{l}\text { Sum of } \\
\text { Squares }\end{array}$ & $\begin{array}{c}\text { Mean } \\
\text { Square }\end{array}$ & F Value & \\
\hline Model & 17 & 741.41 & 43.61 & 8.03 & $<0.0001$ \\
\hline Error & 90 & 488.67 & 5.43 & & \\
\hline \multirow[t]{2}{*}{ Corrected Total } & 107 & 1230.07 & & & \\
\hline & DF & Type III SS & $\begin{array}{c}\text { Mean } \\
\text { Sqaure }\end{array}$ & F Value & $\operatorname{Pr}<\mathrm{F}$ \\
\hline Cultivar & 5 & 600.30 & 120.06 & 22.11 & $<0.0001$ \\
\hline Treatment & 2 & 87.46 & 43.73 & 8.05 & 0.0006 \\
\hline Treatment $\mathrm{x}$ cultivar & 10 & 53.65 & 5.36 & 0.99 & 0.4597 \\
\hline \multicolumn{5}{|c|}{ SAS, GLM Procedure, t Tests (LSD), First Day of Harvest 2011} & \\
\hline Alpha 0.05 & & t Grouping & Mean & $\mathrm{N}$ & Treatment \\
\hline Error DF 90 & & $\mathrm{~A}$ & 210.75 & 36 & Control \\
\hline \multicolumn{2}{|c|}{ Error Mean Square 5.43} & $\mathrm{~B}$ & 209.47 & 36 & Low \\
\hline \multicolumn{2}{|c|}{ Critical Value of t 1.99} & $\mathrm{~B}$ & 208.55 & 36 & High \\
\hline \multicolumn{2}{|c|}{ Least Significant Difference 1.09} & & & & \\
\hline
\end{tabular}




\begin{tabular}{|c|c|c|c|c|c|}
\hline \multicolumn{5}{|c|}{ SAS, GLM Procedure: First Day of Harvest ANOVA test 2012} & \multirow[b]{2}{*}{$\operatorname{Pr}<\mathrm{F}$} \\
\hline Source & $\begin{array}{l}\text { Degrees of } \\
\text { Freedom } \\
\text { (DF) }\end{array}$ & $\begin{array}{l}\text { Sum of } \\
\text { Squares }\end{array}$ & $\begin{array}{c}\text { Mean } \\
\text { Square }\end{array}$ & F Value & \\
\hline Model & 17 & 6331.53 & 372.44 & 37.64 & $<0.0001$ \\
\hline Error & 89 & 880.63 & 9.89 & & \\
\hline \multirow[t]{2}{*}{ Corrected Total } & 106 & 7212.17 & & & \\
\hline & DF & Type III SS & $\begin{array}{c}\text { Mean } \\
\text { Sqaure }\end{array}$ & F Value & $\operatorname{Pr}<\mathrm{F}$ \\
\hline Cultivar & 5 & 313.60 & 62.72 & 6.34 & $<0.0001$ \\
\hline Treatment & 2 & 5858.16 & 2929.08 & 296.02 & $<0.0001$ \\
\hline Treatment $\mathrm{x}$ cultivar & 10 & 134.07 & 13.41 & 1.35 & 0.2145 \\
\hline \multicolumn{6}{|c|}{ SAS, GLM Procedure, t Tests (LSD), First Day of Harvest 2012} \\
\hline Alpha 0.05 & & $\begin{array}{l}\text { Treatment } \\
\text { Comparison }\end{array}$ & $\begin{array}{c}\text { Difference } \\
\text { between } \\
\text { Means }\end{array}$ & \multicolumn{2}{|c|}{$\begin{array}{l}\text { 95\% Confidence } \\
\text { Limits }\end{array}$} \\
\hline Error DF 89 & & Control-Low & 11.42 & \multicolumn{2}{|c|}{$9.94-12.89$} \\
\hline Error Mean Square 9. & & Control-High & 17.95 & \multicolumn{2}{|c|}{$16.47-19.44$} \\
\hline Critical Value of $t 1.9$ & & Low-High & 6.52 & \multicolumn{2}{|c|}{$5.05-8.02$} \\
\hline \multicolumn{2}{|c|}{ Least Significant Difference 1.09} & & & & \\
\hline
\end{tabular}




\begin{tabular}{|l|}
\hline 3-way loglinear statistics, Fruit Distribution 2011, week $x$ treatment $x$ cultivar \\
number of cells in table: 108 \\
\hline week $x$ treatment $x$ cultivar \\
$\mathrm{G}=92.7(\mathrm{P}=0.0002, \mathrm{df}=50)$ \\
$\mathrm{G}($ Williams $)=90.665(\mathrm{P}=0.0004)$ \\
\hline Lil Loupe $2011:$ Fruit Distribution, Treatment $\mathrm{x}$ week \\
sample size $=18$, critical ChiSquare $=18.31, \mathrm{df}=10$ \\
$\mathrm{G}=32.39(\mathrm{P}=0.0003)$ \\
$\mathrm{G}($ Williams $)=29.97(\mathrm{P}=0.0009)$ \\
\hline Sivan $2011:$ Fruit Distribution, Treatment $\mathrm{x}$ week \\
sample size $=18$, critical ChiSquare $=18.31, \mathrm{df}=10$ \\
$\mathrm{G}=53.60(\mathrm{P}<0.0001)$ \\
$\mathrm{G}($ Williams $)=51.05(\mathrm{P}<0.0001)$ \\
\hline Sweet Granite $2011:$ Fruit Distribution, Treatment $\mathrm{x}$ week \\
sample size $=18$, critical ChiSquare $=18.31, \mathrm{df}=10$ \\
$\mathrm{G}=45.00(\mathrm{P}<0.0001)$ \\
$\mathrm{G}($ Williams $)=42.13(\mathrm{P}<0.0001)$ \\
\hline Tasty Bites $2011:$ Fruit Distribution, Treatment $\mathrm{x}$ week \\
sample size $=18$, critical ChiSquare $=18.31, \mathrm{df}=10$ \\
$\mathrm{G}=51.01(\mathrm{P}<0.0001)$ \\
$\mathrm{G}($ Williams $)=46.99(\mathrm{P}<0.0001)$ \\
\hline
\end{tabular}




\begin{tabular}{|l|}
\hline 3-way loglinear statistics, Fruit Distribution 2012, week $x$ treatment $x$ cultivar \\
number of cells in table: 72 \\
\hline week $x$ treatment $x$ cultivar \\
$\mathrm{G}=198.11(\mathrm{P}=0.0, \mathrm{df}=30)$ \\
$\mathrm{G}($ Williams $)=189.09(\mathrm{P}=0.0)$ \\
\hline Athena 2012: Fruit Distribution, Treatment $\mathrm{x}$ week \\
sample size $=12$, critical ChiSquare $=12.59, \mathrm{df}=6$ \\
$\mathrm{G}=59.67(\mathrm{P}<0.0001)$ \\
$\mathrm{G}($ Williams $)=54.87(\mathrm{P}<0.0001)$ \\
\hline Earlichamp $2012:$ Fruit Distribution, Treatment $\mathrm{x}$ week \\
sample size $=12$, critical ChiSquare $=12.59, \mathrm{df}=6$ \\
$\mathrm{G}=38.21(\mathrm{P}<0.0001)$ \\
$\mathrm{G}($ Williams $)=36.04(\mathrm{P}<0.0001)$ \\
\hline Lil Loupe $2012:$ Fruit Distribution, Treatment $\mathrm{x}$ week \\
sample size $=12$, critical ChiSquare $=12.59, \mathrm{df}=6$ \\
$\mathrm{G}=28.94(\mathrm{P}<0.0001)$ \\
$\mathrm{G}($ Williams $)=27.13(\mathrm{P}=0.0001)$ \\
\hline Sivan $2012:$ Fruit Distribution, Treatment $\mathrm{x}$ week \\
sample size $=12$, critical ChiSquare $=12.59, \mathrm{df}=6$ \\
$\mathrm{G}=39.28(\mathrm{P}<0.0001)$ \\
$\mathrm{G}($ Williams $)=38.01(\mathrm{P}<0.0001)$ \\
\hline Sarah's Choice $2012:$ Fruit Distribution, Treatment $\mathrm{x}$ week \\
sample size $=12$, critical ChiSquare $=12.59, \mathrm{df}=6$ \\
$\mathrm{G}=48.73(\mathrm{P}<0.0001)$ \\
$\mathrm{G}($ Williams $)=47.23(\mathrm{P}<0.0001)$ \\
\hline Tasty Bites $2012:$ Fruit Distribution, Treatment $\mathrm{x}$ week \\
sample size $=18$, critical ChiSquare $=18.31, \mathrm{df}=10$ \\
$\mathrm{G}=47.2518(\mathrm{P}<0.0001)$ \\
$\mathrm{G}($ Williams $)=45.69(\mathrm{P}<0.0001)$ \\
\hline
\end{tabular}




\begin{tabular}{|c|c|c|c|c|c|c|c|c|}
\hline \multicolumn{9}{|c|}{ SAS, NPAR1WAY:Fruit Number, Wilcoxon Scores (Rank Sums)\& Kruskal-Wallis Test } \\
\hline Year & $\begin{array}{c}\text { Total } \\
\text { number of } \\
\text { plots }\end{array}$ & $\begin{array}{l}\text { Sum of } \\
\text { Scores }\end{array}$ & $\begin{array}{l}\text { Expected } \\
\text { under HO }\end{array}$ & $\begin{array}{c}\text { Std Dev } \\
\text { under HO }\end{array}$ & $\begin{array}{l}\text { Mean } \\
\text { Score }\end{array}$ & $\begin{array}{l}\text { Chi- } \\
\text { Square }\end{array}$ & $\mathrm{DF}$ & $\begin{array}{l}\mathrm{P}<\text { Chi- } \\
\text { Square }\end{array}$ \\
\hline 2011 & 90 & 9410 & 8145 & 348.81 & 104.6 & \multirow{2}{*}{13.2} & \multirow{2}{*}{1} & \multirow{2}{*}{0.0003} \\
\hline 2012 & 90 & 6880 & & 348. & 76.4 & & & \\
\hline \multicolumn{9}{|c|}{ Treatment: Control } \\
\hline 2011 & 30 & 1168.5 & 915 & 67.4 & 38.9 & \multirow{2}{*}{14.1} & \multirow{2}{*}{1} & \multirow{2}{*}{0.0002} \\
\hline 2012 & 30 & 661.5 & 915 & 67.4 & 22.1 & & & \\
\hline \multicolumn{9}{|c|}{ Treatment: High } \\
\hline 2011 & 30 & 1219.5 & 915 & 67.3 & 40.7 & \multirow{2}{*}{20.5} & \multirow{2}{*}{1} & \multirow{2}{*}{$<0.0001$} \\
\hline 2012 & 30 & 610.5 & 915 & 67.3 & 20.4 & & & \\
\hline
\end{tabular}

\begin{tabular}{|l|c|c|c|c|c|}
\hline \multicolumn{7}{|c|}{ SAS, GLM Procedure: Avg Fruit Size ANOVA test } & & \\
\hline Source & $\begin{array}{c}\text { Degrees of } \\
\text { Freedom } \\
\text { (DF) }\end{array}$ & $\begin{array}{c}\text { Sum of } \\
\text { Squares }\end{array}$ & $\begin{array}{c}\text { Mean } \\
\text { Square }\end{array}$ & F Value & $\operatorname{Pr}<$ F \\
\hline Model & 29 & 31.70 & 1.10 & 60.8 & $<0.0001$ \\
\hline Error & 150 & 2.70 & 0.02 & & \\
\hline Corrected Total & 179 & 34.41 & & & \\
\hline & DF & Type III SS & Sqaure & F Value & $\operatorname{Pr}<$ F \\
\hline Cultivar & 4 & 24.50 & 6.88 & 382.47 & $<0.0001$ \\
\hline Treatment & 2 & 0.16 & 0.08 & 4.39 & 0.014 \\
\hline Year & 1 & 1.33 & 1.33 & 73.83 & $<0.0001$ \\
\hline Treatment x year & 2 & 2.04 & 1.02 & 56.69 & $<0.0001$ \\
\hline Trt x cv x year & 8 & 0.32 & 0.04 & 2.24 & 0.0273 \\
\hline
\end{tabular}




\begin{tabular}{|c|c|c|c|c|c|}
\hline \multicolumn{5}{|c|}{ SAS, GLM Procedure: Marketable Yields ANOVA test } & \multirow[b]{2}{*}{$\operatorname{Pr}<\mathrm{F}$} \\
\hline Source & $\begin{array}{c}\text { Degrees of } \\
\text { Freedom } \\
\text { (DF) }\end{array}$ & $\begin{array}{l}\text { Sum of } \\
\text { Squares }\end{array}$ & $\begin{array}{c}\text { Mean } \\
\text { Square }\end{array}$ & F Value & \\
\hline Model & 29 & 4002.30 & 138.00 & 16.72 & $<0.0001$ \\
\hline Error & 150 & 1238.20 & 8.25 & & \\
\hline \multirow[t]{2}{*}{ Corrected Total } & 179 & 5240.40 & & & \\
\hline & DF & Type III SS & $\begin{array}{c}\text { Mean } \\
\text { Sqaure }\end{array}$ & F Value & $\operatorname{Pr}<\mathrm{F}$ \\
\hline Cultivar & 4 & 2248.01 & 562.00 & 68.09 & $<0.0001$ \\
\hline Treatment & 2 & 583.88 & 291.93 & 35.37 & $<0.0001$ \\
\hline Year & 1 & 228.79 & 228.79 & 27.72 & $<0.0001$ \\
\hline Cultivar x year & 4 & 194.61 & 48.65 & 5.89 & 0.0002 \\
\hline Treatment $\mathrm{x}$ year & 2 & 566.97 & 283.49 & 34.34 & $<0.0001$ \\
\hline Trt x cv x year & 8 & 131.75 & 16.47 & 2 & 0.0507 \\
\hline \multicolumn{6}{|c|}{ SAS, GLM Procedure: Cull Yields ANOVA test } \\
\hline Source & $\begin{array}{c}\text { Degrees of } \\
\text { Freedom } \\
\text { (DF) }\end{array}$ & $\begin{array}{l}\text { Sum of } \\
\text { Squares }\end{array}$ & $\begin{array}{l}\text { Mean } \\
\text { Square }\end{array}$ & F Value & $\operatorname{Pr}<\mathrm{F}$ \\
\hline Model & 29 & 469.83 & 16.20 & 5.83 & $<0.0001$ \\
\hline Error & 150 & 416.53 & 2.78 & & \\
\hline \multirow[t]{2}{*}{ Corrected Total } & 179 & 886.37 & & & \\
\hline & DF & Type III SS & $\begin{array}{c}\text { Mean } \\
\text { Sqaure }\end{array}$ & F Value & $\operatorname{Pr}<\mathrm{F}$ \\
\hline Cultivar & 4 & 146.15 & 36.54 & 13.16 & $<0.0001$ \\
\hline Year & 1 & 74.11 & 74.11 & 26.69 & $<0.0001$ \\
\hline Treatment $\mathrm{x}$ cV & 8 & 59.12 & 7.39 & 2.66 & 0.0093 \\
\hline Cultivar x year & 4 & 146.23 & 36.55 & 13.16 & $<0.0001$ \\
\hline
\end{tabular}




\begin{tabular}{|l|c|c|c|c|c|}
\hline \multicolumn{7}{|c|}{ SAS, GLM Procedure: Total Yields ANOVA test } & & \\
\hline & $\begin{array}{c}\text { Degrees of } \\
\text { Freedom } \\
\text { (DF) }\end{array}$ & $\begin{array}{c}\text { Sum of } \\
\text { Squares }\end{array}$ & $\begin{array}{c}\text { Mean } \\
\text { Square }\end{array}$ & F Value & $\operatorname{Pr}<$ F \\
\hline Model & 29 & 3618.40 & 124.77 & 13.03 & $<0.0001$ \\
\hline Error & 150 & 1436.63 & 9.57 & & \\
\hline Corrected Total & 179 & 5055.02 & & & \\
\hline & DF & Type III SS & $\begin{array}{c}\text { Mean } \\
\text { Sqaure }\end{array}$ & F Value & Pr $<$ F \\
\hline Cultivar & 4 & 1550.24 & 387.56 & 40.47 & $<0.0001$ \\
\hline Treatment & 2 & 629.65 & 314.83 & 32.87 & $<0.0001$ \\
\hline Year & 1 & 562.09 & 562.09 & 58.69 & $<0.0001$ \\
\hline Treatment $x$ year & 2 & 622.83 & 311.42 & 32.51 & $<0.0001$ \\
\hline
\end{tabular}

\begin{tabular}{|l|c|c|c|c|c|}
\hline \multicolumn{7}{|c|}{ SAS, GLM Procedure: Percent Soluble Solids ANOVA test } & \\
\hline Source & $\begin{array}{c}\text { Degrees of } \\
\text { Freedom } \\
\text { (DF) }\end{array}$ & $\begin{array}{c}\text { Sum of } \\
\text { Squares }\end{array}$ & Mean Squar & F Value & $\operatorname{Pr}<$ F \\
\hline Model & 29 & 314.17 & 10.83 & 4.18 & $<0.0001$ \\
\hline Error & 150 & 373.00 & 2.59 & & \\
\hline Corrected Total & 179 & 687.18 & & & \\
\hline & DF & Type III SS & Mean Sqau & F Value & Pr $<$ F \\
\hline Cultivar & 4 & 47.97 & 11.99 & 4.63 & 0.0015 \\
\hline Treatment & 2 & 98.99 & 49.49 & 19.11 & $<0.0001$ \\
\hline Year & 1 & 88.04 & 88.04 & 33.9 & $<0.0001$ \\
\hline
\end{tabular}




\begin{tabular}{|l|c|c|c|c|c|}
\hline \multicolumn{7}{|c|}{ SAS, GLM Procedure: Location Effect, Total Yields ANOVA test } & \\
\hline Source & $\begin{array}{c}\text { Degrees of } \\
\text { Freedom } \\
\text { (DF) }\end{array}$ & $\begin{array}{c}\text { Sum of } \\
\text { Squares }\end{array}$ & $\begin{array}{c}\text { Mean } \\
\text { Square }\end{array}$ & F Value & $\operatorname{Pr}<\mathrm{F}$ \\
\hline Model & 19 & 1891.11 & 99.53 & 14.53 & $<0.0001$ \\
\hline Error & 40 & 274.06 & 6.85 & & \\
\hline Corrected Total & 59 & 2165.17 & & & \\
\hline & DF & Type III SS & Sqaure & F Value & $\operatorname{Pr}<\mathrm{F}$ \\
\hline Cultivar & 4 & 729.21 & 182.30 & 26.61 & $<0.0001$ \\
\hline Year & 1 & 871.10 & 871.10 & 127.13 & $<0.0001$ \\
\hline Cc x location x year & 4 & 153.23 & 38.31 & 5.59 & 0.0011 \\
\hline
\end{tabular}




\section{Chapter 3}

\begin{tabular}{|c|c|c|c|c|c|}
\hline \multicolumn{4}{|c|}{ SAS, GLM Procedure: Total Fruit ANOVA test } & \multirow[b]{2}{*}{ F Value } & \multirow[b]{2}{*}{$\operatorname{Pr}<\mathrm{F}$} \\
\hline Source & $\begin{array}{c}\text { Degrees of } \\
\text { Freedom (DF) }\end{array}$ & $\begin{array}{l}\text { Sum of } \\
\text { Squares }\end{array}$ & Mean Square & & \\
\hline Model & 7 & 458.28 & 65.50 & 7.83 & $<0.0001$ \\
\hline Error & 52 & 434.70 & 8.35 & & \\
\hline \multirow[t]{2}{*}{ Corrected Total } & 59 & 892.98 & & & \\
\hline & DF & Type III SS & Mean Sqaure & F Value & $\operatorname{Pr}<\mathrm{F}$ \\
\hline Treatment & 2 & 50.63 & 25.32 & 3.03 & 0.057 \\
\hline Year & 1 & 303.75 & 303.75 & 36.34 & $<0.0001$ \\
\hline \multicolumn{6}{|c|}{ SAS, GLM Procedure: Avg. Fruit Size 2012 ANOVA test } \\
\hline Source & $\begin{array}{c}\text { Degrees of } \\
\text { Freedom (DF) }\end{array}$ & $\begin{array}{l}\text { Sum of } \\
\text { Squares }\end{array}$ & Mean Square & F Value & $\operatorname{Pr}<\mathrm{F}$ \\
\hline Model & 6 & 2.48 & 0.42 & 16.88 & $<0.0001$ \\
\hline Error & 22 & 0.54 & 0.02 & & \\
\hline \multirow[t]{2}{*}{ Corrected Total } & 28 & 3.03 & & & \\
\hline & $\mathrm{DF}$ & Type III SS & Mean Sqaure & F Value & $\operatorname{Pr}<\mathrm{F}$ \\
\hline Treatment & 2 & 0.49 & 0.25 & 10.09 & 0.0008 \\
\hline
\end{tabular}




\section{BIBLIOGRAPHY}

Adams, S.R., V.M. Valdés, P.J.C Hamer, and B.J. Bailey. 2000. Spatial variation and comparison of yields of tomatoes in small experimental compartments with those in large commercial units. Acta Horticulturae. 534:93-100.

Agricultural Marketing Services, 2008. U.S. Department of Agriculture. United States standards for grades of cantaloupes. 5 May 2012. < ww.ams.usda.gov/AMSv1.0/ getfile?dDocName=STELPRDC5050255>

Ajzen, I., T.C. Brown, and L.H. Rosenthal. Information bias in contingent valuation: Effects of personal relevance, quality of information, and motivational orientation. $\mathrm{J}$ Env. Econ. Mangt. 30:43-57.

Bachmann, J. 2005. Season extension techniques for market gardeners. ATTRA. 2 Feb $2011<$ http://www.okfarmtoschool.com/pdf/attra-seasonext.pdf>

Bianco, V.V. and H.K. Pratt. 1977. Compositional changes in muskmelons during development and in response to ethylene treatment. J. Amer. Soc. Hort. Sci. 102:127133.

Blomgren, T. and T. Frisch. 2007. High tunnels: using low cost technology to increase yields, improve quality, and extend the season. Cornell Coop. Ext. 3 Jan 2012. <http://www.uvm.edu/sustainableagriculture/hightunnels.html> Bonanno, A.R., and W.J. Lamont. 1987. Effect of polyethylene mulches, irrigation method, and row covers on soil and air-temperature and yield of muskmelon. 112:735738.

Bond, J.K., D. Thilmany, and C.A. Bond. 2006. Direct marketing of fresh produce: Understanding consumer purchasing decisions. Choices. 21:229-2236. 
Blomgren, T. and T. Frisch. 2007 High tunnels: using low cost technology to increase yields, improve quality, and extend the season. Cornell Coop. Ext. 3 Jan 2012. <http://www.uvm.edu/sustainableagriculture/hightunnels.html> Bouwkamp, J.C., F.F. Angell, and F.D. Schales. 1978. Effects of weather on soluble solids of muskmelon. Scientia Hortic. 8:265-271.

Bumgarner, N., and S. Verlinden. 2010. Effects of water inclusion in microcliamte modification systems for warm and cool season vegetable crops on temperature and yield. J. Appl. Hort. 12:87-92.

Capinera, J.L. 2009. Featured creatures: Melon aphid or cotton aphid. Unv. of Florida. 23 Mar 2013. <http://entnemdept.ufl.edu/ Creatures/veg/aphid /melon_aphid.htm>

Carlsson, F. and P. Martinsson. 2001. Do hypothetical and actual marginal willingness to pay differ in choice experiments? J Env. Econ. Mangt. 41:179-192.

Carey, E. E., J. Lewis, W. J. Lamont Jr., T.T. Nennich, M. D. Orzolek, and K. A. Williams. 2009. Horticultural crop production in high tunnels in the United States: A snapshot. HortTechnology. 19:37-43.

Carpio, C.E., and O. Isengildina. 2009. Consumer willingness to pay for locally grown products: The case for South Carolina. Agribusiness. 25:412-426.

Clarkson, V.A. and W.A. Frazier. 1957. Effect of paper and polyethylene mulches and plastic caps on cantaloupe yields and earliness. Proc. Am. Soc. Hort. Sci. 69:400404. 
Cline, G.R., J.D. Sedlacek, S.L. Hillman, S.K. Parker, and A. F. Silvernail. 2008. Organic management of cucumber beetles in watermelon and muskmelon production. HortTechnology. 18:436-444.

Conner D.S., K.B. Waldman, A.D. Montri, M.W. Hamm, and J.A. Biernbaum. 2010. Hoophouse contributions to economic viability: Nine Michigan case studies. HortTechnology. 20:877-884.Dag, A. and D. E. Eiskowitch. 1999. Ventilation of greenhouses increases honey bee foraging activity on melon, Cucumis melo. J. Apicul. Research. 38:169-175.

Dag, A. and D. E. Eiskowitch. 1999. Ventilation of greenhouses increases honey bee foraging activity on melon, Cucumis melo. J. Apicul. Research. 38:169-175.

Darby, K., M.T. Batte, S. Ernst, and B. Roe. Willingness to pay for locally produced foods: A customer intercept survey of direct market and grocery store shoppers. 2 Jan 2013. < http://ageconsearch.umn.edu/bitstream/21336/1/sp06da03.pdf>

Darby, K., M.T. Batte, S. Ernst, and B. Roe. 2008. Decomposing local: A conjoint analysis of locally produced foods. Amer. J. Agr. Econ. 90:476-486.

Default, R.J., A. Korkmaz, B.K. Ward, and R.L. Hassell. 2006. Planting date and cultivar affect melon quality and productivity. HortScience. 41:1559-1564.

Delahaut, K.A. 2001. Garden facts: Vegetable aphids. Unv. of Wisconsin Ext. 23 Mar 2013. < http://richland.uwex.edu/files/2012/07/A3757-E.pdf>

Diamond, A., and R. Soto. 2009. "Facts on Direct-to-Consumer Food Marketing: Incorportating Data from the 2007 Census of Agriculture. U.S. Depart. of Agricul. Agriculture Marketing Ser.: Washington. 5 Dec 2012 <http://www.ams.usda.gov/AMSv1.0/getfile?dDocName=STELPRDC5076729> 
Dickerson, G.W. 2004. Row cover vegetable production techniques. Guide H-251. 12 April 2011 <http://aces.nmsu.edu/pubs/h/H251/welcome.html>

Dickie, M., A. Fisher, and S. Gerking. 1987. Market transactions and hypothetical demand data: A comparative study. Amer. Stat. Assoc. 82:69-75.

Dimitri, C., A. Effland, and N. Conklin. 2005. The $20^{\text {th }}$ century transformation of U.S. Agriculture and farm policy. U.S. Dept. Agri. Econ. Resch. Ser. Econ. Info. Bltn. 3. Accessed 3 Feb 2013. < http://ageconsearch.umn.edu/bitstream/59390/2/eib3.pdf> Drost, Dan. 2011. High Tunnel summer squash production. Utah State Unv. Coop. Ext. 13 Jan 2013<http://extension.usu.edu/files/publications/publication/Horticulture _HighTunnels_2011-01pr.pdf>

Eastwood, D.B., J.R.Brooker, and R.H. Orr. 1987. Consumer preferences for local versus out-of-state grown selected fresh produce: The case of Knoxville, Tennessee. Southern J. Agr. Econ. 19:183-194.

FarmFreshRI. RI Farmers Market Manager Guide. 15 Jan 2013. < http:// www.farmfreshri.org/about/markets_managerguide.php> Fisher, R.M., and N. Pomeroy. 1989. Pollination of greenhouse muskmelons by bumble bees (Hymenoptera: Apidae). J. Econ. Ent. 82: 1061-1066.

Gent, M.P.N. 1991. High tunnels extend tomato and pepper production. CT. Ag. Exp. Stat. Ext. Ser. Bul. 893. 28 Dec 2012 <http://ia700403.us.archive.org/4/items/ hightunnelsexten00gent/hightunnelsexten00gent.pdf> Giacomelli, G.A. 2009. Engineering principles impacting high-tunnel environments. HortTechnology. 19:30-33. 
Giraud, K.L., C.A. Bond, and J.J Bond. 2005. Consumer preferences for locally made specialty food products across northern New England. Agr. Res. Econ. Rev. 34:204216.

Govindasamy, R., J. Italia, and A. Adelaja. 2002. Farmers' markets: Consumer trends, preferences, and characteristics. J. Extension. 30 April 2012. < http://www.joe.org /joe/2002february/rb6.php>

Gruda, N. 2005. Impact of environmental factors on product quality of greenhouse vegetables for fresh consumption. Critical Rev. Plant Sci. 24:227-247.

Ham, J.M., G.J. Kluitenberg, and W.J. Lamont. 1993. Optical properties of plastic mulches affect temperature regime. J. Amer. Hort. Sci. 118:188-193.

Hemphil, D. 1985. Muskmelon response to floating row covers. 23 Dec $2012<$ http://horticulture.oregonstate.edu/content/muskmelon-response-floating-row-covers1984>

Hemphill, Jr., D.D. and N.S. Mansour. 1986. Response of muskmelon to three floating row covers. J. Amer. Soc. Hort. Sci. 111:513-517. Hill, D.E. 1997. Effects of multiple cropping and row covers on production of specialty melons. CT Ag. Exp. Station. Ext. Ser. Bul. 745. 21 Dec 2012 <http://ia700603.us.archive.org/10/items/effectsofmultipl00hill/effectsofmultipl00hill. pdf $>$

Howell, J. C., and R. V. Hazzard, eds. 2010-2011. New England Vegetable Management Guide. 12 Nov 2012 <www.nevegetable.org>

Hu, W., T. Woods, S. Bastin. 2009. Consumer willingness to pay for blueberry products with nonconventional attributes. J. Agr. Appl. Econ. 41:47-60. 
Hu, W., T. Woods, and S. Bastin. 2009. Consumer acceptance and willingness to pay for blueberry products with nonconventional attributes. J. Agri. Appl. Econ. 41:47-60. Hu, W. M.T. Batte, T. Woods, and S. Ernst. 2012 Consumer preferences for local production and other value-added label claims for a processed food product. Euro. Rev. Agr. Econ. 39:489-510.

Hubbard, J.A. 2011. An inexpensive alternative solar radiation shield for ambient air temperature micro-sensors. J. Nat. Environ. Sci. 2:9-14.

Ibarra, L., J. Flores, and J.C. Díaz-Pérez. 2001. Growth and yield of muskmelon in response to plastic mulch and row covers. Scientia Hort. 87:139-145.

Iselin, W.A., M.H. Jensen, and H.G. Sprangler. The pollination of melons in air inflated greenhouses by honey bees. Environ. Ent. 3:664-666.

James, Rosalind R. and Theresa L. Pitts-Singer, eds. 2008. Bee pollination in agricultural ecosystems. New York: Oxford Univ. Press

Jekanowski, M.D., D.R. Williams II, and W.A. Schiek. 2000.Consumers' willingness to purchase locally produced agricultural products: An analysis of an Indiana survey. Agr. Res. Econ. Rev. 29:43-53.

Jett, L. W. 2006a. High tunnel melon and watermelon production. Univ. Missouri Coop. Ext. Ser. Bul. M173. 9 Mar $2012<$ http://extension.missouri.edu/p/ M173>

Jett, L.W. 2006b. Galia muskmelons: A potentially profitable early-season crop for high tunnels in the Central Great Plains. Univ. Missouri Coop. Ext. Ser. 2 Jan $2013<$ http://www.hightunnels.org/PDF/JETT\%20Production\%20Melons.pdf>

Knewtson, S. J. B., E. E. Carey, and M. B. Kirkham. 2010. Management practices of 
growers using high tunnels in the central Great Plains of the United States.

HortTechnology. 20:639-645.

Kremen, C., N.M. Williams, and R.W. Thorp. Crop pollination from native bees at risk from agricultural intensification. PNAS. 99:16812-16816.

Kultur, F., H.C. Harrison, and J.E. Staub. 2001. Spacing and genotype effect fruit sugar concentration, yield, and fruit size of muskmelon. HortScience. 36:274-278. Lament Jr., W.J. 1993. Plastic mulches for the production of vegetable crops. HortTechnology. 3:35-39.

Lamont Jr., W.J. 2005. Plastics: Modifying the microclimate for the production of vegetable crops. HortTechnology. 15:477-481.Lamont, Jr., W.J. 2009. Overview of the use of high tunnels worldwide. . 19:25-29.

Lamont, Jr., W.J. 2009. Overview of the use of high tunnels worldwide. 19:25-29. Lamont, W. J., M. R. Mc Gann, M. D. Orzolek, N. Mbugua, B. Dye, and D. Reese. 2002. Design and construction of the Penn State high tunnel. HortTech. 19: 37-43. Lamont, W.J., M.D. Orzolek, E.J. Holcomb, K.Demchak, E. Burkhart, L. White, and B. Dye. 2003. Production system for horticultural crops grown in the Penn State high tunnel. 13:358-362.

Lingle, S.E., and J.R. Dunlap.1987. Sucrose metabolism in netted muskmelon fruit during development. Plant Phys. 84:386-389.

Loy, J. B., and O. S. Wells. 1975. Response of hybrid muskmelons to polyethylene row covers and black polyethylene mulch. Scientia Hort. 3:223-230.

Lusk, J.L., and D. Hudson. Willingness-to-pay estimates and their relevance to agribusiness decision making. Rev Agr. Econ. 26:152-169. 
MacGillivray, J.H. 1947. Soluble solids content of different regions of watermelons. Plant Physiol. 22:637-640.

Martinez, S., M. Hand, M. Da Pra, S. Pollack, K. Ralston, T. Smith, S. Vogel, S.

Clark, L. Lohr, S. Low, and C. Newman. 2010. Local food systems: Concepts, impacts, and issues. USDA. Econ. Res. Ser. Report No. ERR-97. Accessed 10 May 2012. < http://www. ers.usda.gov/publications/err-economic-research-report/ err97 .aspx\#.UbNkCfbTXiM >

Mayen, C. and M.I. Marshall. 2005. Consumer preference for a fresh-cut melon product-A potential value added product for melon growers. Accessed 12 Feb 2013. <https://www.ifama.org/events/conferences/2005/cmsdocs/1140_Paper_Final.pdf> McGregor, S. E., M. D. Levin, and R. E. Foster. 1965. Honey bee visitors and fruit set of cantaloupes. J. Econ. Ent. 58:968-970.

Martinez, S. M. Hand, M. Da Pra, S. Pollack, K. Ralston, T. Smith, S. Vogel, S. Clark, L. Lohr, S. Low, and C. Newman. Local food systems: Concepts, impacts, and issues. USDA. Econ. Res. Ser. www.ers.usda.gov/publications/err97

Motsenbocker, C.E., and A.R. Bonanno. 1989. Row cover effects on air and soil temperatures and yield of muskmelon. HortScience. 24:601-603.

Mueller, D.S., M.L. Gleason, A.J. Sisson, and J.M. Massmaan. 2006. Effect of row covers on suppression of bacterial wilt of muskmelon in Iowa. 21 Dec 2012<http://www.plantmanagementnetwork.org/pub/php/research/2006/muskmelon/> Mussen, E. C. and R. W. Thorp. Honey bee pollination of cantaloupe, cucumber and watermelon. Univ. Cal., Davis: Coop. Ser. Ext. Bul. 7224.

Nair, A. and M. Ngouajio. 2010. Integrating rowcovers and soil amendments for 
organic cucumber production: Implications on crop growth, yield, and microclimate. HortScience. 45:566-574.

National Agriculture Statistics Service (NASS). 2009. U.S. Census of Agriculture. Small farms fact sheet. USDA: Washington. 3 May 2012 <http://www.agcensus.usda.gov/Publications/2007/Online_Highlights/Fact_Sheets/Far m_Numbers/small_farm.pdf>

National Climate Data Center (NCDC). National Oceanic and Atmospheric Administration. 23 Dec 2012 < http://www.ncdc.noaa.gov/temp-and-precip/timeseries/index.php?parameter $=$ tmp \&month $=5 \&$ year $=2012 \&$ filter $=1 \&$ state $=37 \&$ div $=0>$ Nearson, H. Relationship between plant density and fruit and seed production in muskmelon. J. Amer. Soc. Hort. Sci. 127:855-859.

Orzolek, M.D. 1996. Stand establishment in plasticulture systems. HortTechnology. 6:181- 185.

Patterson, P.M., and S. Cardona-Martinez. 2004. State and origin branding in Hispanic food markets. J. Food Dist. Research. 35:8-18.

Patterson, P.M. 2006. State-grown promotion programs: Fresher, better? Choices. 21:41-46.

Sassenrath, G.F., J.M. Halloran, D. Archer, R.L Raper, J. Hendrickson, P. Vadas, and J. Hanson. Drivers impacting the adoption of sustainable agricultural management systems of the northeast and southeast Unites States. J. Sust. Agr. 34:680-702. Schales, F.D., and R. Sheldrake Jr. 1965. Mulch effects on soil conditions and muskmelon response. Amer. S. Hort. Sci. 88:425-430. 
Soltani, N., Anderson, J.L., Hamson, A.R., 1995. Growth analysis of watermelon plants with mulches and row covers. J. Am. Soc. Hort. Sci. 120:1001-1009. Tarara, J.M. 2000. Microclimate modification with plastic mulch. HortScience. $35: 169-180$.

The Providence Plan. Providence Neighborhoods Plans. Sliver Lake and West End. Accessed 9 June 2013. < http://local.provplan.org/profiles/\# >

U.S. Census Bureau. 2010. American Fact Finder: North Kingston town, Washington County, Rhode Island. Accessed 9 June 2013. < http://factfinder2. census.gov/faces/tableservices/jsf/pages/productview.xhtml?src=bkmk > U.S. Dept. of Agriculture (USDA). 2007. U.S. Census of Agriculture. "Small Farms Fact Sheet." USDA: Washington. Accessed 20 May $2012<$ http://www.agcensus.usda .gov/Publications/2007/Online_Highlights/Fact_Sheets/Farm_Numbers/small_farm.pd f >

Waterer, D. 1992. Influence of planting date and row covers on yield and crop values for bell peppers in Saskatchewan. Can. J. Plant Sci. 72:527-533.

Waterer, D. 1993. Influence of planting date and row covers on yield and economic value of muskmelons. Can. J. Plant Sci. 73:281-288.

Waterer, D. 2003. Yields and economics of high tunnels for production of warmseason vegetable crops. HortTechnology. 13:339-343.

Wells, O.S. 1991. Amer. Veg. Grower High tunnels shelter early crops. 39:46-47.

Wells, O.S. and J.B. Loy. 1985. Intensive vegetable production with row covers. HortScience 20:822-825. 
Wells, O.S. and J.B. Loy. 1993. Production and marketing reports: Rowcovers and high tunnels enhance crop production in the northeastern United States.

HortTechnology. 3:92-95.

Wells, J.A. and P.E. Nugent. 1980. Effect of high soil moisture on quality of muskmelon. HortScience. 15:258-259.

Wells, O.S. and M.R. Sciabarrasi. 1992. High tunnels extend the season for tomatoes. HortScience. 27:661-662. (Abstr.)

Wiebe, J. 1973. Tunnel covers and mulches for muskmelon production. Can. J. Plant Sci.53: 157-160.

Wien, H.C. 2009. Microenvironmental variations within the high tunnel. HortScience. $44: 235-238$.

Williams, P.R.D., and J.K. Hammitt. 2000. A comparison of organic and conventional fresh produce in the Boston area. Risk Analysis. 20:735-746.

Whorton, C. 2009. Consumers' perceptions and preferences for sustainably-produced fruits and vegetables: The case of organic, local, and small farms. Kansas State Univ. Manhattan. Masters Thesis Abtrs. 10 Jan 2013. < http://krex.k- state.edu/dspace /bitstream/handle/2097/8725/CarlyWhorton2011.pdf?sequence=5>

Wolukau, J.N., X. Zhou, Y. Ling, Y. Zhang, and J. Chen. 2007. Resistance to gummy stem blight in melon (Cucumis melo L.) germplasm and inheritance of resistance from plant introductions 157076, 420145, and 323498. HortScience. 42:215-221.

U.S. Dept. of Agriculture (USDA). 2007 U.S. Census of Agriculture. Small farms fact sheet. USDA: Washington. 3 May $2012<$ http://www.agcensus.usda.gov/ Publications/2007/Online_Highlights/Fact_Sheets/Farm_Numbers/small_farm.pdf> 
USDA, NRCS. 2012. EQIP Seasonal high tunnel initiative fact sheet. 3 May 2012 <http://www.nrcs.usda.gov/Internet/FSE_DOCUMENTS/stelprdb1046338.pdf > USDA Historical Census Publications. 22 Dec 2012 <http://www.agcensus.usda.gov /Publications/Historical_Publications/index.php> 